


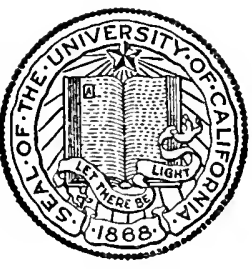

THE LIBRARY

OF

THE UNIVERSITY

OF CALIFORNIA

RIVERSIDE 
Benj-1? Kur है.

Way 1, 120?

at. 
Digitized by the Internet Archive in 2008 with funding from Microsoft Corporation 
THE

FOREIGN DEBT OF ENGLISH

LITERATURE 
LONDON: GEORGE BELL AND SONS PORTUGAL ST. LINCOLN'S INN, w.C. CAMBRIDGE : DEIGHTON, BELL \& CO. NEW YORK: THE MACMILLAN CO. BONIPAY : A. H. WHEELER \& $\mathrm{CO}$ 


\section{THE FOREIGN DEBT of $)_{f}$ \\ ENGLISH LYTERATERE B)

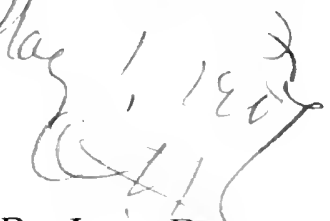 \\ T. G. TUCKER, LitT.D.}

professor of classicad. philology in the UNIVERSity OF Melbovrne.

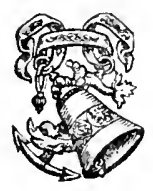

LONDON

GEORGE BELI, AND SONS

I907 


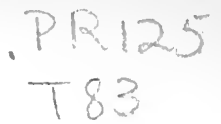

CIISWICK PRESS: CHARLES WHITTINGHAM AND CO. TOOKS COURT, CHANCERY LANE, IONDON. 


\section{PREFACE}

THE following unpretentious chapters are 1 intended to offer to the ordinary student, who has not yet given the matter any particular thought, a first assistance in realizing the interdependence of literatures. They aim at clearness, and at as great a measure of accuracy as is permitted by the compass within which the matter is necessarily compressed. No pretence whatever is made to completeness. The summaries of various literatures do not profess to be more than epitomes with a special object. If, while helping to that end, they are also readable in themselves, their purpose is served.

It is, perhaps, advisable to state that, while the professional studies of the writer have been for the most part concerned with the literatures of Greece and Rome, it has more than once fallen to his lot to promote academic teaching in the literature of England. It was this 
experience which suggested the present attempt at a more general survey. French, Italian, and German literatures have been approached at first hand, although the standard works have been duly consulted. With the literature of Spain contact has been less intimate, but care has been taken to check impressions formed under these conditions. For the rest the best authorities have been used and trusted.

Inasmuch as guiding hints and clues are often more helpful than elaborate treatises, a special acknowledgment is due to various writings of Professor Churton Collins and Professor W. P. Ker. 


\section{CONTENTS}

INTRODUC'TORY

I. GREEK LITERATURE AND ENGLISH . 5

II. LATIN LITERATURE AND ENGLISH . 7o

III. LITERARI CURRENTS OF THE DARK AGES . . . . . . . . . . . . I I6

IV. FRENCH LITERATURE AND ENGLISH I 36

V. ITALIAN LITERATURE AND ENGLISH ${ }^{1} 78$

VI. OTHER INFLUENCES SUMMARIZED . 216

(a) Spayish Literature and English · 216

(b) German Literature and English • $23 \mathrm{I}$

(c) Celtic Literature and Exglish . . 247

(d) Hebrew Influence . . . . . . 253

INDEX • . . . . . . . . . . . . . 259

SYNOPTICAL TABLES

I. Table of Greek Literature.

2. View of Relations with Greek Liter.iture.

3. T.able of Latin Literature.

4. Table of French Literature.

5. 'Table of Italian Literature.

6. Table of Spanish Literature.

7. Table of German Literature.

8. Some Points in the Pedigree of Poetry.

9. Some Points in tile Pedigree of Epic Verse. 



\section{ENGLISH LITERATURE}

\section{IN'TRODUC'TORY}

A JUST appreciation of any modern European that literature alone. Not one has grown up spontaneously and independently from the soil of the national genius. Some seeds at least have come from elsewhere. Often whole forms of writing have been transplanted bodily. We must particularly recognize these truths when dealing with English literature.

The basis of the English mind is chiefly Teutonic, in some measure Celtic. If the English genius had been left to itself, to develop its spiritual and intellectual creations in its own way, English literature would have been a very different thing in both substance and form. But in reality English literary history is the story of the Teutonic and Celtic tendencies "corrected and clarified," and the Teutonic and Celtic invention immensely assisted, by influences and ideas flowing in from other sources. There have been large ingraftings from other stocks, either partially kindred or altogether alien-from Greeks, Romans, Italians, French, Spaniards, Germans, as well as from Hebrews and other Orientals.

All sound study is comparative. We must place other literatures beside our own, if we desire to appraise rightly our national genius, its capacities, and 
its creations. We find our English writers composing their works in certain forms, and giving expression to a certain range of ideas. How came they to employ these particular forms of creation? How did they arrive at these particular ideas? How is it with other nations? Have they built upon the same lines and with the same materials, or how is it with them? Have we borrowed from them, or they from us? If there have been borrowings, when and in what measure did they occur? Looking back over the changes of spirit and form which our poetry, for example, has undergone, we shall encourage altogether false notions of the causes of such changes, unless we see how, every now and then, a shower of new ideas, a stream of new light, has come in from abroad. Most readers know in some vague way that Chaucer avows or betrays his debts to France and Italy; that Shakespeare did not invent his own plots, but borrowed from Italians, from Plautus, from Plutarch, and others; that Milton was steeped in the Greek, Latin, and Italian classics. But we want to know more than this. We want to perceive with some definiteness how far the whole course of English literature has been enriched by tributary streams, and what sort of waters they brought. It would be instructive to draw a diagram of our literary history; to liken it to the course of a river, and to picture its various fountain-heads and tributaries pouring in their several quotas at their several times.

In all modern literatures there is a large proportion which is unoriginal to them. Milton has been mentioned already. Those who read only English works find Milton full of nobility of thought and imagery. 
Yet, before Milton produced his greater poems, he had read, re-read, and deliberately steeped himself in, the literature of Greece, Rome, modern Italy, and France. Precisely how much of Milton is made up of Homer, Euripides, Virgil, Dante, Ariosto, and other predecessors, can only be known to such as have those authors at their finger-ends. Shelley, again, is commonly regarded as one of the most daringly original of English writers. Yet Shelley's mind was an amalgam of himself, Homer, Euripides, Plato, Virgil, Dante, Calderon, Goethe; and this, once more, is but another way of saying that it had incorporated the genius of generations of Greeks, Romans, Spaniards, Italians, and Germans. We cannot therefore arrive at the true genius of Milton or of Shelley, or speak understandingly of their originality, until we have surveyed those other literatures and their relations with our own.

Let us, indeed, claim with a proper national pride that the influence of English literature, of our Shakespeare, our Bacon, our Locke, our Byron, upon foreign writers has been profound. Her debt to modern literature has been repaid by England, and, at least in the influence of Shakespeare, more than repaid. But with that question we are not here concerned.

One prefatory remark has yet to be made. It is that there is no discredit in this literary borrowing. Nations can no more be independent in the art of literature than in other arts. To be independent, to be unaffected by others' genius, inaccessible to others' ideas, would be to render our literature as stagnant and as grotesque as the paintings of China and of old Japan. It is a condition of progress in 
literature as in science, that new inspiration must be continually sought, new conceptions assimilated. Onevein is soon worked out; another must be opened. True art is of all the world, and a nation does best in art when it corrects its own peculiar faults and expands its own particular ideas, without meanwhile surrendering itself to a servile imitation of that for which its genius is naturally unfit. And English writers may glory that they have seldom been servile imitators. 


\section{I}

\section{GREEK LITERATURE AND ENGLISH}

F all the literatures which have contributed to that of England, the Greek is by far the first and most important. The study of Greek literature is the indispensable introduction to the study of European literary history. Whether we review the literature of England, of Italy, of France, or of Germany, it is at Greece that we shall ultimately arrive. Take our English epic, Paradise Lost. It is a commonplace that it derives much inspiration from Dante's Divine Comedy. But, when we arrive at the Divine Comedy, we are assured that it would never have taken such shape but for Virgil's Aeneid. And, when we come to Virgil's Aeneid, it is a fact known to the veriest tiro that the Aeneid is a copy, and, in a sense, a plagiarism, of Homer's Iliad and Odyssey. The pedigree is self-evident and undeniable. Practically it is avowed at every step. Look elsewhere. Pope and Shenstone wrote "pastorals," after the fashion introduced into English by Spenser. But Spenser himself had been led to this form of composition by the Italian Sannazaro and the Latin Virgil. And, when we reach Virgil, we find that he is a liberal borrower, in matter and manner alike, sometimes 
even in the very phrase, from the Greek of Theocritus, Bion, and Moschus. It is the same with literary criticism. Pope's Essay on Criticism, like Roscommon's Essay on Translated Verse, is derived from Boileau's French Art Poétique. But Boileau is an echo of the Latin Horace and his De Arte Poetica, while Horace is himself a borrower from Greeks of Alexandria, and ultimately from Aristotle of Athens. And so it is throughout. Often, especially in these later days, our stars of English literature shine with a light reflected directly from Greek constellations. No less often they shine with a light transmitted through several media, but ultimately issuing from the suns of Greece.

Pre-eminent by far among the literatures to which we owe a debt stands this body of eternally great creators, who, by the clear beauty of their language, their luminous apprehension, and their simple but magnificent originality, surpass in the aggregate those whom any other nation can assemble. It is no paradox, but a simple historical fact, that the old English writers have had less influence in moulding our modern literature than have Homer and Sophocles, Plato and Demosthenes. "We are all Greeks," says Shelley, in the preface to his Hellas. Whether we will or no, our literature and philosophy, our canons of taste, our ideals of art, are all, in a sense, Greek.

Greek literature, unlike Latin, and unlike those of modern Europe, was mainly, if not wholly, original. What we have been able to borrow or to find readymade seems to have developed itself spontaneously 
in the wonderful genius of Greece. Latin literature has been called-and not without some justice-one vast plagiarism from Greek. But Greek itself is guiltless of plagiarism. Its thoughts, like its exquisite clearness and restraint of style, are almost entirely its own. With unlettered barbarians to north and west of them, with flowery, bombastic, or mystic orientals on the Asiaward side, the Greeks must be credited with a marvellous gift of their own, the instinct for sound judgement and sure taste.

But they possessed more than taste and judgement. They had inventiveness. We may reflect for a moment upon the various forms and modes of literature which we possess and practise in verse and prose. Of verse there are the epic, lyric, elegiac, satiric, dramatic, didactic, pastoral, epigrammatic, philosophic varieties. In prose there are history, oratory, philosophy, biography, criticism, fiction. To us all these forms and species, with their appropriate language, metre and tone, are taken for granted, as if they were the necessary outcome of some natural order of things. They are, no doubt, founded in nature. Nevertheless, we should remember that they must have had a beginning of their differentiation, that they must have been invented somewhere. And we discover that each of them is to be found arising in recognizable shape on the soil of ancient Greece. It is easy nowadays for us to imitate existing forms, to build with the architecture of the drama of Shakespeare and the epic of Milton, to copy the lyrical metres of Gray, Shelley, and Tennyson, to adopt the satirical machinery of Pope and Dryden. But these differentiations in mode of expression re- 
present something deeper, some distinction evolved by the human mind between compositions of one purpose and compositions of another. It was the Greeks who first convincingly and systematically illustrated that distinction, and who found for each subject of thought its appropriate vehicle of expression. More modern times have evolved many modifications of detail in metre or rhyme, and have essayed many novelties in the way of narrative. But they have never addled an entirely new form of poetry or prose to the répertoire of the Greeks. Tennyson does not write In Memoriam in the metre and language of Paradise Lost. Shelley's Ode to a Skylark does not employ the diction and rhythm of Pope's Essay on Man. It is recognized that the feeling and its vehicle would be incongruous. But how does this come to be recognized? A world is quite conceivable in which there might have been developed but one form of literature and one ideal of expression. In such a world the incongruity would not be felt. The early Hellenes made their own literary beginnings upon almost a clear field, and it is one of their imperishable glories that they succeeded in realizing the subtle relations between language and thought or feeling, and in expressing these latter in all the variety of extant literary forms. For heroic deeds and lofty incident they developed the epic verse; for the sweets and bitters of love, and for other passions and ardours, they built the lyric stanza; for the plaints of mourning they created the elegiac; they did this gradually, no doubt, and in the main unconsciously, but with all the more perfect result. If we inherit what Greece has created, we have no 
right to assume that all our happy varieties of literary form are things of course, which would somehow have come to any nation.

* * * * * * * * * *

The history of Greek literature should be a study of years. Nevertheless it is not without profit to take the greater names and the more prominent types, to show their order of succession, to say something of their range and scope, to note the essentials of their style, and thence to derive some clearer idea of their influence on what we read to-day in our own English tongue.

The earliest Greek books which we now possess are Homer's Iliad and Odyssey. But these are much too polished and perfect works to have been the very first that Greeks ever composed. Indeed we know that before Homer's time there were minstrels, who sang the "glories" of heroes, very much after the manner in which the bards sang in Wales or Scotland, or the gleemen in Anglo-Saxon England. It must also be assumed that popularsongs of a religious kind were in existence. Yet all these earliest efforts at literary creation have vanished; we possess no material for definite information concerning them. For us Greek literature begins with " Homer." The question as to who Homer was cannot be answered. Some critics contend that he is a mere title, and that the compositions which go by his name are patchworks, made up of a series of narratives sung by wandering bards called "rhapsodists." Homêros, they say, is but a fictitious title under which to string all these separate compositions together into one socalled epic. Others, going less far, say that there 
was indeed a veritable Homer, that he composed a poem on the Wrath of Achilles, and that this poem has been enlarged by other hands, which turned the whole in to the Iliad, or poem on the "Siege of Troy". Even if this be true, we know nothing of the original Homer, when or where he lived. To discuss the question at any length is beyond our present province. Perhaps we may believe, with great masters of poetry like Goethe and Schiller, that a "Homer" wrote the poem of the Iliad, but that it has since been added to, tampered with, reconstructed. We may also believe that some one other poet wrote a corresponding portion of the Odyssey. These two original poets were of nearly, though not quite, the same period. They were inspired with much the same literary ideals, and were almost equal, though by no means identical, in genius. They may be supposed to have appeared in a specially fertile epoch, like the great Elizabethans, or like the Italian poets of the first Renaissance. Their artistic principles would be much the same; they would live in much the same environment; they would see the world, the gods, mankind, through much the same moral temperament. Let us grant that their work has undergone large interference and contamination. Yet it is hard to think that a motley crowd of rhapsodists could ever possess such a lofty average of genius as pervades the whole body of these inimitable poems. Both works were, beyond reasonable doubt, in complete existence before 800 B.c. Twenty-seven centuries ago the Greek genius had reached thus high a point.

The Iliad and the Odyssey are to be read in many a translation. The Iliad is the poem of Ilium or 
Troy. It deals with events during the siege of that town by the confederated Achaeans. It narrates the doings and sayings of the Grecian heroes, of Agamemnon, Achilles, Ajax, Ulysses, Diomede, Menelaus, outside Troy, and of the Trojans, King Priam, Hector or Paris within the city, where is also the traitress Helen. It narrates the counsels, quarrels, and battles of the gods, as they arise from partisanship during the siege. The poem is filled with prowess of battle, till it ends with the death of Hector, champion of Troy. The narrative is rapid and vigorous, full of valorous and exciting exploits of men interwoven with the friendly or unfriendly actions of gods. Descriptions are many, but always brief, and everywhere inimitably fresh and luminous. The whole purpose of the poem is to tell a story, and to tell it with clearness and simplicity, yet with fire and force. When it is embellished with ornaments of simile or other figure, it is because that device best brings home the picture. There is no idle lavishing of ornament for mere ornament's sake.

The Odyssey is the poem of Odysseus, the wandering Ulysses. He, the king of the little island of Ithaca, after being for ten years absent at the siege of Troy, starts homeward in his ship to his wife, Penelope. But on the journey he meets with adventures, strange, terrible, or happy. He is stormtossed and delayed by the anger of offended gods. He nearly meets his death from the one-eyed cannibal monster Polyphemus; he nearly loses his crew among the Lotus-eaters; he is detained for seven years in the island of the seductive Calypso; his comrades are turned into swine by Circe the en- 
chantress; he is wrecked between Scylla and Charybdis. He at last arrives home, only to find Penelope at the mercy of a rabble calling themselves her suitors. He slays them, and reveals himself to his wife-and so a happy ending. In this poem, as in the Iliad, composed nearly three thousand years ago, there is already achieved a perfection of literary art which we moderns find ourselves for ever aiming at and for ever missing. For this there is other reason than the natural genius of the Greek. The poets who wrote these two stories looked out upon the world with a frank, unclouded gaze, for which, perhaps, we are now too sophisticated. They therefore tell their tale with such simple directness that it might seem told by a grown-up child; but meanwhile with such brilliant clearness, with such firm outline, that it no less appears the work of a consummate artist. There is, it is true, no psychological probing in these books. There is no subtle moralizing, no pondering of any kind of deep question. Nowhere does there obtrude itself a desire to be clever, rhetorical, dazzling. Yet no one can read the Iliad without seeing those warriors face to face, as they were, in their physical strength and simplicity of character; nor can he read the Odyssey without feeling that he is with Ulysses on his raft, sailing through the deep, blue Mediterranean, that the salt breeze is blowing on his face, that the world is young and fresh, and that a man's part is to perform that which lies nearest to his hand.

What effect the Iliad and the Odyssey have upon the intelligent reader may be judged by their preeminence among poems of all times and all places. 
What an effect they have had on our literature may be judged by the number of translations, many in prose, and many better known in verse, from the hands of Chapman, Pope, Cowper, Derby, Morris, Way. It may be judged by the countless allusions to the " tale of Troy divine" which are strewn through every book of the last three millennia; by our everyday familiarity with the names of Hector and Achilles, Helen of Troy and Paris, Diomede and Ulysses, Circe and Penelope, Polyphemus and the Lotus-eaters. On reading Chapman's Homer, Keats felt like an astronomer "when a new planet swims into his ken." The same experience has been felt by all who recognize, as Keats did, " the principle of beauty in all things." But little notion of those poems can be gathered at secondhand. Of its similes we may here quote one, not because it is in any way the most beautiful, but because it has been translated by a master in the art, Tennyson. Nothing in English has ever been hit upon to give the majestic, sonorous roll of the Greek hexameter, but Tennyson has, at least, preserved the frank simplicity of his original:

As when in heaven the stars about the moon Look beautiful, when all the winds are laid, And every height comes out, and jutting peak And valley, and the immeasurable heavens Break open to their highest, and all the stars Shine, and the shepherd gladdens in his heart: So many a fire between the ships and stream Of Xanthus blazed before the towers of Troy, A thousand on the plain; and close by each Sat fifty in the blaze of burning fire; And eating hoary grain and pulse the steeds, Fixed by their cars, waited the golden daw'n. 
Next to Homer may come, by no means in importance, but in date, the poet Hesiod. He, too, uses the hexameter line, but with a different tone and movement, and for quite another purpose. He is our first example of "didactic" verse-the verse which is intended to instruct. Hesiod, who may be dated about the year joo B.c., composed two poems of some dimensions, the one called the Theogony or Pedigree of the Gods, the other known as the Works and Days. The latter is a collection of versified rules of agriculture mixed with proverbial wisdom. It is, in fact, a sort of " Farmer's Annual " of Greece combined with the proverbial wisdom of "Poor Richard." Practical farming and practical morals go together. It would almost certainly have been written in prose, but for the simple reason that prose literature had not yet been invented. All literary composition begins with verse. As a poem, there is little to be said for the Works and Days, except that, like all things early Greek, it is entirely unpretentious and goes straight to the point. Didactic verse has grown common since Hesiod's day, although happily it is now seldom used for agricultural purposes. Tusser's Five Hundred Points of Good Husbandry is one of the earliest results of the revival of Greek studies in England in the Elizabethan time, and, though it cannot count for much in literature, it is our first example of a species of work which took a more moralizing shape in Dyer's Fleece and many later didactics.

Of much more value is the next kind of poetry which arose among the Greeks, a kind which has been called " personal," inasmuch as it is prompted 
by the writer's individual feelings and emotions, and has reference to himself, his hopes, griefs, loves, and other sentiments. The epic poetry of Homer had been purely objective, dealing with incidents, things, and men outside the poet. The author makes no revelation of himself; he does not speak in the first person. But what is known as "lyric" and "elegiac" poetry is the outcome of a man's own inner experience, and is only valuable in proportion as it expresses powerfully or touchingly a real or imagined passion of the writer, which the world at large can also recognize for its own. The poetry of Lycidas, Adonais, In Memoriam, is "elegiac"; the poetry of songs, such as those of Herrick and Burns, is "lyric." "Elegiac" properly means "adapted to mourning," but the elegy, with its couplet rhythm varied from the hexameter, yet with a plaintive dignity all its own, was used for other feelings than those of grief. It was used for praise, exhortation, reflection, love; for anything "subjective," or springing from the mood of the writer. We need not enumerate the Greeks who at various dates wrote poetry of this personal description. After the year 700 B.c. there were many and excellent lyrists of the kind. At Lacedaemon the poet Tyrtaeus composed marching songs, which acted upon the Spartans as the Marseillaise and Die Wacht am Rhein act upon nations in modern days. Archilochus of Paros, soured by his own failings and misfortunes, wrote often in bitterness, like Burns. He is styled an "iambic" writer from a new form of composition which he employed, and he became the first great name in satire. In Lesbos, a fertile, luxurious, and 
cultured island, we meet with the foremost name in the poetry of passion, the famous Sappho, the first and greatest of women in literature. It is Sappho who could paint, better than poet has ever painted since, the agonizing of love. Nor was she alone. In the same island she had her school of followers, and, separately from these, the poet Alcaeus poured forth his fiery thoughts in "words that burn." But it is Sappho who, like George Sand, wrote from the "real blood of her heart and the real flame of her thought" things which have been the despair of imitator or translator. Unhappily, very little of her work is extant now, even in fragments; but what there is, is " more golden than gold." Her metres are as nobly simple as in one of Herrick's songs; her words are simple also. Yet, just as Dante could make a mighty verse out of the noun and verb, by choosing for his noun and verb the absolutely truest and most home-coming, so the simplicity of Sappho is only a deceptive covering for the most consummate art. Often as our lyrists have tried to catch something of her sacred fire, never has one quite attained to her irresistible pathos. Perhaps he who has approached nearest is Burns. Sappho is untranslatable. All absolutely best words in any language must be so. The nearest equivalent in English may be sought and found for the best word in the Greek, but in the special quality of its music or its associations it can never be the same.

The names of Pindar and Simonides are of a later date. Before them comes another, who sang to the lyre those gemlike songs of love, and joy, and wine, which the cavalier poets of the English seventeenth 
century made their ideal. This was Anacreon of Teos. "Anacreontics" is the name given to those polished cameo-like little poems which imitators have essayed upon Anacreon's themes. Cowley's translations into English verse are known to literature, and readers familiar with the works of Thomas Moore will remember his loose youthful version of a few true and many spurious lyrics of the Teian bard. It is to Anacreon that we may look for the prototype of those graceful trifles called vers de société, and of those songs of love or gaiety which Herrick, Suckling, Lovelace, and Waller have developed in such exquisite examples.

All this personal poetry was meant to be sung to the accompaniment of lyre or flute. Had it been primarily meant to be read, it might possibly, even with Greek creators, have been less simple and direct, more artificial.

There was also another class of poetry which was sung to the same accompaniment. Early Greece found many occasions for festivities, and at religious holidays, public rejoicings, and publicthanksgivings, choruses sang while moving in procession or while dancing round the altars. Hymns were chanted to the gods, triumphal odes were chanted in honour of men. When literature turned to these-or when these became literature-there arose in particular two most famous poets, Simonides and Pindar, to compose such public odes, very much after the manner in which a modern laureate might compose an ode of installation or national victory, or a dirge upon a national loss. Compositions written in this spirit are seldom of the highest rank of literature. 
They lack the saving grace of inspiration. Pindar is strong, noble, imaginative. His odeswere, no doubt, splendid compositions for chanting and musical purposes. To read them is to be conscious of a stateliness and dignity and an "eagle flight" which powerfully affect the student. But, full as they are of great imagery and diction, they are beyond doubt apt to be artificial and perplexed in structure; they are too often obscure, too often deliberately learned in allusion. To be its best, poetry must be written from the promptings of the poet's heart, and Pindar too often wrote to order, for payment, and not from inward compulsion. No exact, or very near, parallel to Pindar can be found. He has never been even tolerably well translated. This has not been for want of admirers. Gray, who imitated him in the Progress of Poesy, has been said by Mason (erroneously enough) to possess Pindar's fire: Cowley's tombstone calls him, without much justification, the English Pindar, and at all times down to the present writers have been led to emulate the soaring Pindaric ode. Whateverhis defects, it is certain that over all modern lyric poets, even over those who could not always follow his meaning, Pindar has exercised the sway of a master and imperial spirit.

Among the kinds of poetry chiefly affected by the earlier Greeks must also be included the "gnomic" or "sententious" verse which goes under the names of Theognisand Phocylides. These writers both lived in the sixth century B.c., and both composed versified maxims or precepts of conduct and worldly wisdom. After times came to credit to those great originals 
any verses of this character which were current in the elegiac or the hexameter metre, and such verses played very much the same part in Greek mouths as is played by the Proverbs of Solomon or by proverbial philosophy of unknown authorship in the mouths of Englishmen. At a later date in the iambic metre the comic poet Menander introduced into his plays a large number of maxims, which gained wide vogue and which caused many more of the same species to be fathered upon him. Of the various wise saws thus current in Greece a great number were translated or adapted by Latin writers, and have so passed into the general possession of the European world.

Between the years 500 and 400 B.C. there arose in Athens that which is the special poetic glory of that city-the drama, embracing both the drama of tragedy, as wrought by Aeschylus, Sophocles, and Euripides, and the drama of comedy, as built by Aristophanes, and later, in a different form and spirit, by Menander.

The Attic drama arose on Grecian ground. At one time choruses danced round the altar of the wine-god Dionysus (or Bacchus), and chanted songs in his honour. The chorus had its leader, the Coryphaeus. In time it became the fashion for the Coryphaeus to personate the god, or some character whom story connected with him. He recited a speech, or related some legend, in which the wine-god was concerned. It naturally followed that he was next raised upon a low dais, and distinguished from the rest of the chorus. The dais later became the clramatic 
stage. Subsequently another member of the chorus was told off to converse with him in rough dialogue, the theme being still the history of Bacchus. So far, then, we have a chorus which dances and sings, and two actors supporting crude dramatic parts. It was from these simple beginnings that there grew to perfection in Athens, as suddenly as the Shakespearean perfection arose from the old miracle-plays and "moralities" in England, noble dramas like those of Aeschylus and Sophocles. The open sward had become a theatre, the acting art, the dialogue poetry. Drama had been raised to an art of the most absolute literary completeness. It must, however, be observed that the tragedy which grew up in this way was religious in its origin. Until the end it-theoretically at least-remained so. Its subject-matter and laws were, therefore, limited. The stage was at the same time a pulpit for moral and religious teaching. The theatre was, moreover, national. Here are some important elements of artistic difference. Those who read Shakespeare and then turn to Athenian tragedies are puzzled. They do not understand those Attic creations. They think them rather cold, with somewhat slender plot, containing few surprises. Italians and Frenchmen can understand them; the average Englishman cannot. The poetry is often admirable, but the action appears strangely simple, and for the most part over obvious. The very name "tragedy" seems sometimes misapplied. But by "tragedy" the Greeks did not necessarily mean a play which ends in death and disaster. Such an end was, indeed, usual, and hence the modern meaning of the term. But the Eumenides 
of Aeschylus ends happily, as do the Alcestis of Euripides and the Philoctêtes of Sophocles. The Greeks meant rather the working out of some great and powerful situation affording occasion for sensations of pity and fear. Here was "the luxury of grief." The spectators knew that there would be some climax in the drama; but whether it would issue in good or evil depended on the poet; they only knew that their feelings would be powerfully worked upon by great poetry greatly delivered. For the rest, they required no startling ingenuity of plot or variety of incident.

The three great dramatists in artistic sequence are Aeschylus, Sophocles, Euripides. These were all alive together, but Aeschylus was old when Euripides was young. The appearance of all these in one epoch is exactly paralleled by the cluster of superlative dramatists in the Elizabethan age or in the France of Louis XIV. Of Sophocles it has been said that he represented men as they ought to be, and of Euripides that he represented them as they were. The dictum is hardly true, and, if it were, it must be noted that, whereas to "hold the mirror up to nature" is as much the function of Greek tragedy as of English, it is no function of Greek drama to be a literal copy of literal everyday human experience. In Aeschylus all is in the grand style of an aweinspiring simplicity. Take his Prometheus Bound. We have a majestic Titan figure bound to a desolate rock, there to remain in punishment for an offence against the law of Zeus. He had bestowed fire and other boons on mortal men. Therefore Zeus pinioned him on Caucasus for tens of thousands of years. In 
one way, and one only, could he gain his freedomby disclosing to Zeus a certain secret of fate. But Prometheus would not repent of having exercised his benevolent freewill against the decree of Heaven. He gloried in his action; he refused to deliver up the secret. Now during the whole play the figure of Prometheus does not move: he is fixed fast. There is no action on his part, nothing but speech. Different gods, demigods, and a mortal visit him, condole with him, advise him, or threaten him. He remains firm to the end, the spectacle of an utterly resolute heart rebelling against fate.

It is not hard to recognize in English literature some of the characters to which this Prometheus has served as prototype. There is Milton's Satan, who is distinctly modelled on the Titan. Byron acknowledges that all his rebellious spirits, Cain, Manfred, and their like, are echoes of the same character. Shelley wrote a Prometheus Unbound for sequel. Keats's Hyperion shows the same influence. Swinburne's Atalanta in Calydon is throughout inspired by the conception of Aeschylus.

Ancient drama has much attracted the modern poet. The Agameminon of Aeschylus has been translated by Browning, far more roughly-not to say grostesquely-in style than it deserves, but with the Greek spirit in no small measure retained. The same writer has translated the Alcestis of Euripides in the work known as Balaustion's Adventure.

But to the English stage Greek tragedies are not suited. Our theatre is not religious, nor national. But in France and Italy Greek plays have found a more congenial soil. Corneille and Racine in France, 
Alfieri in Italy, have sought to mould their dramas upon Greek lines, though, truth to tell, they much more closely suggest the rhetorical constructions of the Latins. The only deliberate attempt to compose in English directly on the Grecian model is Milton's Samson Agonistes, a work in which admirable poetry does not atone for a certain coldness and formality intolerable in drama, whether meant for Greece or for England. Yet inasmuch as the Italian drama was largely instrumental in developing the English from its crude and vulgar antecedents, and as Italian drama was in its turn evoked by the dramatic examples of Greece, we can even here, despite all unlikenesses, distinctly affiliate the main principles of our own stage-pieces to those of ancient Athens. IVe cannot, indeed, maintain that without Athens we should have had no drama; we can only assert that our greatest drama, as we have it, in its poetical dignity and its technical architecture, would hardly have been. It might have been a prose drama, and one of very different conception and ideals. But it is what it is because it took from Greece that which suited its purpose, while it left to Greece those elements which belong to so different a theatre.

It has been described how Greek tragic drama arose from the choruses singing round the altar of Dionysus. Greek comedy springs from the same source. There were two sides to a Greek festival, as there are two sides to Christmas Day. The serious part of the festivity developed serious poetry and serious action. 'The light, sportive, and satirical part developed humorous verse and humorous action. It is easy to see how both dramatic kinds would 
originate from these two different aspects of the feast. From beginnings as rude as those of tragedy was developed the comedy of Aristophanes or of Menander, which in its turn, begat that of Plautus and Terence at Rome, and thence of Shakespeare's predecessors in England and of Molière in France. Even the comic opera of to-day bears a wonderfully close resemblance to plays of Aristophanes, with whom occur almost the same bizarre situations and humours as in Gilbert's very modern eccentricities.

Comedy, like tragedy, had its chorus, chanting appropriate odes during the intervals of acting. And be it noted that the Greek drama, whether tragic or comic, was literary. It bears to be read as much as to be acted; it is a work of conscientious art. In tragedy the writing is pure poetry. In comedy it is humour and wit, biting, sparkling, often coarse and very personal, but always full of life. There was some defence for personality. Comedy, like tragedy, served to give various lessons to the Athenians. Greece possessed no newspapers, and in their place the comic stage served even more than now to criticize fads, to chastise political and private misdoings. So long as it was what is called the "Old Comedy" of Aristophanes it availed itself only too fully of these licences. But when its attacks on politics or private persons became intolerable, its wings were clipped by law, and in the "New Comedy" of Menander we find another tone, the tone of Molière or of Ben Jonson, the treatment of social types, the comedy of domestic intrigue. Of the whims of the "Old Comedy" the following may serve as a specimen. In the Birds of Aristophanes two enterprising Athenians 
persuade the birds to build a city in the clouds"Cloud-cuckoo-town" it is called-by which the ungrateful gods are to be cut off from men, and so forced to come to terms. This is the central idea. Twentyfour persons, equipped as different birds, form the chorus, and give the name to the piece. The central conception, however, is but a peg on which to hang attacks upon the follies of the day, and particularly follies in contemporary politics. Neither parties nor men are spared. Nevertheless the piece is always comedy; it cultivates "the laughable"; it is never mere diatribe.

One other kind of ancient poetry, and a delightful kind as we see it in Greece, is the pastoral idyll of Theocritus, Bion, and Moschus. In English literature the word "pastoral" at once suggests poor triviality, the rather mawkish and always artificial eclogues of Pope or the Shepheard's Calender of Spenser. But, though the conception of these works was ultimately borrowed from Greek through the Latin medium of Virgil, or the Italian medium of Sannazaro, they lack precisely those elements which make the Greek pastoral idyll a thing of beauty and a joy for ever. When Theocritus, about 270 B.c., wrote in Alexandria or elsewhere his "Idylls" or ("little pictures"), hewas portraying a life among Sicilian or Coan shepherds which possessed a large proportion of truth and naturalness. At least it is of real shepherds that he writes, idealizing, perhaps, their Arcadian environment of sunshine and simplicity, but nevertheless presenting a life easily conceivable among entirely possible rustics. He imaged a rural 
scene, placed in it a befitting action or situation, and called his work " a little picture." But when Virgil imitated him at Rome, the Corydons and Damoetases whom he introduces are hardly shepherds of reality. Their talk tends to be artificial and literary. Shepherds did not pipe and contend in alternate minstrelsy on the Italian farms as Greek shepherds had done, however rudely, in Cos or Sicily. Moreover Virgil wrote with an arrière pensée. He was thinking of the society of his time, and more or less representing that society under the guise of obviously theatrical shepherds. In Spenser's Shepheard's Calender we no longer recognize any pretence at reality. The idea of merry witty shepherds piping in sylvan scenes of sunlit Sicily is natural enough; but the notion of the smock-frocked rustic of rainy Britain vying in song with another smock-frocked rustic concerning his Amaryllis or his Chloe is not a little ludicrous. Especially is this so when we know that Colin Clout, Cuddie, Hobbinol, and the other swains, are talking moral wisdom, and are nothing but Spenser's friends or contemporary celebrities with shepherds' crooks for poetic " properties."

Distinguished, however, from pastoral poetry pure and simple, as seen in Pope and Spenser, there is a more important form of creation by these Alexandrian poets, which finds its way into English literature. It is from Theocritus and his school that Milton's Lycidas is drawn, and it is from Lycidas that we get Shelley's Adonais and Matthew Arnold's Thyrsis. Here are two quite unimportant passages, the comparison of which will show at once how 
closely a great English poet may occasionally copy an ancient. Says Theocritus, as translated by Calverley:

The roice of Thyrsis: Etna's Thyrsis $I$.

Where were ye, Nymphs, ol where, while Daphnis pined?

In fair Penëus or in Pindus' glens?

For great Anapus' stream was not your haunt,

Nor Etna's cliff, nor Acis' sacred rill.

Says Milton :

Where where ye, Nymphs, when the remorseless deep

Closed o'er the head of your loved Ly'cidas?

For neither were ye playing on the steep,

Where your old bards, the famous Druids, lie,

Nor on the shaggy top of Mona high,

Nor yet where Deva spreads her wizard stream.

Greek literature is also rich in verse "epigram" in the original sense of the word. In modern times we have come to associate with the epigram the notion of a pithy composition containing a neat and witty point, and particularly a "sting in the tail." This description seldom suits the Greek type, especially in its earlier days, but is derived rather from the custom of the epigrammatists of Rome. An "epigram" was originally a composition to be inscribed upon a monument, votive offering, or the like. That it should be brief was an obvious requirement, and it was natural that it should try to excel mere commonplace. But wit and "point" of a biting kind were alien to the first conception. A Simonides or other early poet wrote a couplet or a quatrain which might be pathetic, eulogistic, or even almost simply descriptive, and this was an "epigram" if actually intended as, or proposed as fit for, 
an inscription. In later times the composition of such pieces was a poetic exercise, the occasion being imaginary, and the tendency to impart point and wit naturally increased. Very many charming little cameo-poems of this kind, touching upon most of the elements of human life, are to be found in what is known as the Greek Anthology, some of the best being of the Graeco-Roman age and written by Romans as well as Greeks throughout the Greek world. Our own epigram, whatever may be its change of character, is derived through French and Latin cliannels-particularly through Martial-from the Greek invention. It is probable also that the Italian, and thence the English, sonnet owes much to the pattern set in the Greek epigram.

$$
\text { * * * * * * * }
$$

In the regions of prose we can hardly be so definite. In history, oratory, philosophy, we still return again and again to the Greeks for inspiration, but the inspiration is chiefly one of spirit, not of outward form or special thoughts.

Herodotus, who began to flourish about 450 B.c., and who writes concerning the Persian invasion of Greece, and, by way of preface, tells of Lydia, Babylon, Egypt, Scythia, is still known as the "Father of history." His undying charm is his style, the style of a delightful story-teller. Clear and clirect as all the best Greek writing is, there is something so fresh, so frank, so suave, about Herodotus, that, even if he tells falsehoods knowingly - as some critics say, but as we need not believe-we cannot grow virtuously indignant with him. He is both uncritical and shrewd-shrewd where the knowledge of his times 
guides him, uncritical where they were ignorant. His stronger-minded contemporary Thucydides is the very pattern of an historian. His function is to tell the history of the long protracted Peloponnesian war, and he tells it inimitably. The graphic terseness of his account is only equalled by his severe impartiality. If he tells you of a battle, he describes luminously its main features, how it went, who won it, and what the consequences were. He does not attempt to minimize or explain away an Athenian defeat or crime because he is an Athenian. If a political party commits an error, he tells us so, and tells us how. It is scarcely possible to find out precisely his own political views. If he describes the terrible plague of Athens or the terrible fall before Syracuse, he describes it with moving pathos. But he does not overdo his part. The pathos is in the distinct simplicity of the picture, not worked up by labour of ambitious words. It is perhaps enough warrant of his excellence that he grew in the admiration of Macaulay with every year of Macaulay's maturing judgement.

In oratory the great name of Demosthenes stands pre-eminent. Volumes of his speeches are in our hands, political and forensic speeches equally. The word "Philippics" has become typical for invective. That Demosthenes is the prince of orators everybody knows. But why? We may imagine the crude aspirant to oratory reading a speech of Demosthenes in amazement, and asking "Where are the flashings of rhetoric? Where the dazzling flights of imagrination? Where the magnificent bursts of diction?" The highest art is to conceal art, and Demosthenes would 
have been no perfect artist if he had allowed the novice to perceive exactly wherein his perfection lay. He is the perfect orator just because he can be graphic, cogent, pathetic, anything he will, without all those rhetorical tropes, purple patches, bouquets of flowery diction, which weaker men are driven to use. His language is like a Greek statue, instinct with a life diffused through every part, but showing no straining at effect, accentuating nothing beyond its value as a persuasive or moving force. His metaphors and similes are few ; often his words are even homely ; but there is a directness, a "home-coming," about his diction and his periods, a dexterity about his arrangement, a noble fervour and simplicity.

In philosophy the Greeks have been the teachers of the civilized world. Two only of their great masters need be considered here. It is said that every man is born either an Aristotelian or a Platonist. This means that there are two chief types of mind which really think, and of those one is akin to the mind of Plato, the other akin to that of Aristotle. Plato is the suggestive, but inconclusive, imaginative, transcendental philosopher. Aristotle is the matter-of-fact, logical, analytical. The style is like the men. The style of Plato is rich with poetical colour, that of Aristotle is hard and thin, prose of the prose. Between them these two cover nearly all the ground of speculative thinking, and modern thought can never emancipate itself from them. For centuries in the Middle Ages the philosophy of Aristotle was almost a religion of civilized Europe, and it is the fact that even now students of morals and politics find themselves constantly returning to 
Aristotle. The Stagirite, as he was called because of his birth at Stagira, lived before the days of experimental science. Yet he virtually anticipated much of modern scientific results. He was nearly an evolutionist. Plato, on the other hand, has had his votaries. $\mathrm{He}$, too, was a religion in Renaissance Italy. Whether we can always follow him or not, he is a stimulating influence, and he has left his mark in many places where one would hardly look for it. We should perhaps scarcely light on Wordsworth's beautiful Ode on the Intimations of Immortality as an echo of Plato. Yet all its fancy concerning "a sleep and a forgetting," and the previous existence of the soul, is pure Plato. Whether Wordsworth was conscious of it or not, his mind had been pervaded by the Platonic influence. Nor was it much otherwise with Shelley. Of direct and appreciable bearing upon literature since his day, is the fact that Plato is our first model of the prose dialogue or imaginary conversation. He did not indeed absolutely invent this form of writing, but the comparatively crude work which preceded him is lost, and it is Plato who stands to Berkeley or Landor as their prototype and exemplar. Centuries later Lucian followed in his steps, though with a somewhat different purpose, combining, as he declared, the philosophical dialogue with the spirit of Attic comedy. Plato's dialogues are always serious in intention, whatever humour or lightness of touch he may display; Lucian's are but partially serious, the humour, which tends to satire, being the predominant element.

A work of Plato to which the world owes much in the way of imitation is his Ideal Commonzecalth 
or Republic, from which are derived in succession the hints for the Civitas Dei or City of God of St. Augustine, the Utopia of Sir Thomas More, the Nerv Atlantis of Bacon, and various minor efforts in the theoretical construction of an ideal polity.

Here we must cease to speak of Greek literature in classical Greece. The subject is inexhaustible.

Yet before we come to illustrate in some detail the effect of all this wealth of original thought and splendid style on English, we must mention two famous writers in the later or "post-classical" period of Greek literature. These introduced new forms of prose writing which have had many imitators in every European country. They are Lucian and Plutarch. Lucian wrote in Syria and in Athens during the later part of the second century of our era. He composed what we should call " articles," in the form of dialogue and essays, nearly all of them of a satirically humorous character, but nearly all possessed of sound common sense and practical purpose. Lucian is the precursor of Swift, Voltaire, and Heine. Of Swift he is the predecessor in more ways than one. Lucian supplies us with the first instance of ironical fiction. His True History is composed in the same ironical vein, and with precisely the same assumption of seriousness, as Swift's Gulliver's Travels. It is to Lucian that Swift owes the hint for such a work, and, after all, the hint was in this case a great part of the genius. The width of Lucian's range may be recognized from the fact that both Swift and Sterne have been called the "English Lucian." 
If Herodotus is the " Father of History," Plutarch (first century A.D.) is the father of biography. Strictly speaking neither is the originator of the form of literature in question; nevertheless each is to be judged rather by the influence of his example than by absolute invention of a literary species. Besides the biographies there exists much other work of Plutarch in the nature of moral essays and "articles" on historical or antiquarian subjects, and this work was liberally drawn upon by essayists after the Revival of Learning, in particular by Montaigne and Bacon. Nevertheless his chief contribution to the development of literature was in his "Parallel Lives," a series of biographies and character-studies, in which a distinguished Greek and a distinguished Roman were studied in comparison, pair by pair. To Shakespeare the Lives were known through North's translation, and, in Coriolanus and the other Roman plays, they supplied not only his conception of antiquity and ancient character, but also the great bulk of the matter which he dramatized. The genesis of modern sketches of the kind represented in Macaulay's Chatham, Lord Clive, or Warren Hastings, can be distinctly traced to similar short studies in the Greek of Plutarch.

A very prolific department of literature, and one which has served as a rich source of inspiration, imitation, and allusion in all subsequent times, was that of the fable. In this domain the name of "Aesop" is supreme. Whether there was ever an historical person bearing precisely this name has been questioned. The tradition which places him in 
Rhodes as a slave in the middle of the sixth century B.C. cannot be implicitly trusted; but it is difficult to understand how the special name of "Aesopus" can have come to attach itself to a series of beast-stories, unless some individual who bore it, or of whom it was a sobriquet, had been distinguished for his invention, or at least for his promulgation, of such satirical narratives. It is indeed almost certain that a large number of "fables of Aesop" originally came from India and the East; yet it is in Greece that Europe first makes acquaintance with those fables which are still the best known, and which most constantly appear in the existing collections or selections. All educated or even sophisticated Greeks were supposed to know "Aesop." At a later time (in the third century A.D.) the GraecoRoman Babrius versified such fables as were known to him, and he again was copied into Latin verse by Avianus. The Indian fables of Pilpay were not circulated in Europe till five centuries later than Babrius, nor did they ever gain such wide currency. It was primarily along the Greek channel that there was derived, if not all the matter, at least the inspiration, for the fables in French by La Fontaine, and the English fables by Gay, together with all the collections which have been printed, or which were current before the days of printing, and which have become part of the répertoire of childhood and a fund of reference for proverbs and for all classes of writers.

Of other kinds of writing which appear already in ancient Greece may be briefly mentioned: 
(I) Character-sketches, first produced by Theophrastus (about 320 B.C.), and imitated by La Bruyère (Characters) in France, and in England in such works as Hall's Characterismes of Virtues and Vices, Overbury's Characters or Witty Descriptions of the Properties of Sundry Persons, and best in Earle's Microcosmography.

(2) Essays in rhetoric, literary criticism, and belles lettres, such as the Rhetoric and Poetics of Aristotle, the latter of which exerted so profound an effect upon the verse, and particularly the dramatic verse, of the French, and thence upon that of the English so-called "classical" school; the essays of Dionysius of Halicarnassus (25 B.c.) upon the style of the Attic orators; and the treatise On Sublimity by Longinus, a writer who cannot be identified, but who wrote in the flourishing times of the Roman imperial epoch; (3) the works in grammar and dictionary-making, which range from the textual criticism and comment of great Alexandrians, like Aristophanes of Byzantium (200 B.C.), to the school grammar of Dionysius Thrax and the lexicons of the early centuries A.D.; (4) geographies and descriptive guidebooks, the former particularly represented by Strabo, about the beginning of the Christian era, and the latter by Pausanias (in the second century A.D.); (5) Miscellanies, antiquarian or literary, such as the famous Pundits at the Dinner-Table of Athenaeus (end of second century A.D.); (6) letters (i.e., fictitious epistles), such as those of Alciphron (second century A.D.); ( 7 ) romances, of which the extant examples are mostly much later than the classical period, those of Longus and 
Heliodorus dating from the latter part of the fourth century A.D.

* $\quad * \quad * \quad * \quad * \quad * \quad * \quad *$

We have have now cursorily surveyed the course of Greek literary history. We have shown that it comprised all the forms of literature now known to us; that in this respect at least we can claim no originality. We have incidentally alluded to some of our debts, though that part of the subject remains to be dealt with more fully. The question which now arises is-what is there distinctive about this Greek literature as a whole, to make it possess such a precious and perpetual salt and savour?

We may reply that, to begin with, the Greek writers were characteristically possessed of one prime literary virtue-lucidity, whether in their picturing of scenes or in their expression of a thought. And they expressed clearly because they saw clearly. Besides being lucid, they were restrained. For the most part they went directly to their point, and did not suffer themselves to be drawn away from the point by irrelevant attractions. They knew, as Lowell puts it, how much writing to leave in the ink-pot. There is so much "not to say." They shrank from overdoing. Floweriness, extravagance, bombast, irrelevance, these were an abomination to classical Greek taste. The Greeks proper did not fail to recognize fustian when they saw it. They were a critical, and a self-critical, people. What we see in the purity of their sculpture and architecture, we may see in their literature. A word or phrase must have a rational and artistic purpose, or it must not be there. 
Again, they were eminently sane men, those Greeks. They looked out on the world with eyes like those of their Goddess of Wisdom, the imperturbable eyes of unabashed intelligence. What they saw they saw frankly: they knew facts from fancies, and recognized facts when they met them. They were mentally a healthy people, not constitutionally given to moodiness and mysticisms and impossible aspirations. They took meanwhile a wholesome delight in living, and in the boons of physical life.

This whole way of looking at things has received a name of its own. It is styled "Hellenism." The Greeks called their country "Hellas," and themselves "Hellenes." Hence this name, which means so much. Hellenic thought means direct and fresh, if not always profound, thought; Hellenic art means art of consummate simplicity, art of clear principle. Hellenic style means in literature a perfect directness and lucidity, with just so much of the figurative as will flash light upon the sense.

This is what is meant by "Classical" Hellenism. True, no scholar would dare to say that even in the classical age every Greek who has left us a book or a fragment was always as perfect as Greek principles and ideals were perfect. Homer sometimes nods. We may find palpable blemishes not a few. But we must judge a national literature as a whole; and when, as with the Greek, a literature can show so large a proportion which is flawless, when it is so obviously informed with one and the same artistic spirit, so manifestly controlled by the same canons of taste, then we may use our general 
terms with more confidence than we can usually feel in generalizing of whole peoples and their histories.

In later times, when Greece was no longer free, when cultured Greeks had been scattered into Asia Minor, Syria, and to Alexandria, when literature became mere reading, then Greek art and letters lost their prime virtue. Oratory declined, as poetry had done. Greek writing became more oriental, more "Asian" in its artificiality. In classical Greek the ornamentation was not compassed for its own sake. It grew spontaneously out of the subject and helped the subject. But when Greek literature became " unclassical," when it became artificial, mere imitation and make-believe, when it was not the outcome of a national spirit, but was forced in the hotbeds of literary coteries and courtfavour, then ornamentation was first and foremost; poems and speeches were composed in order to bring in fine things. Rhetoric grew bombastic and poetry finical; or, as it is commonly expressed, literature became "Asiatic" instead of "Attic." This literature in general is sometimes called "Hellenistic," rather than "Hellenic"; but that term should be appropriated to other purposes. Its headquarters being at Alexandria, the title "Alexandrian" has come to be virtually a term of disparagement in literature.

When therefore we speak of the influence of Greek literature on English, we include not merely a fund of classical history and of mythology, not merely a long list of Greek words and Greek allusions, not 
even merely an inheritance of all the great forms of poetry and prose writing, but also that way of looking at things and that style of putting things which we call Hellenic. We mean not only so many similes, metaphors and figures of speech, but a whole scope of thinking and style.

We might, indeed, in some rough way, gauge the influence of Greece by the mere titles of English books or compositions bearing such Greek names as Utopia, Arcadia, Comus, Pindaric Odes, Endymion, Hellas, Prometheus Unbound, Hellenics, Life and Death of Jason, The Lotus-Eaters. We might gauge it in some measure by the allusions scattered up and down from Chaucer to Tennyson, allusions to Homer and his Agamemnon, Achilles and Hector, his Circe and all the beings of his mythology, to Greek history, to Plato and Aristotle. We might gauge it in a measure by terms like Parnassus, Clio, Helicon, Academe, and similar references to the literary haunts and divinities of Greece. We might further take the Greek words which now form part of our English vocabulary.

But the subject requires more methodical treatment, and perhaps some little retrospect. Meanwhile we may well assert with Shelley:

But Greece and her foundations are

Built below the tide of war,

Based on the crystalline sea

Of thought and its eternity;

Her citizens, imperial spirits,

Rule the present from the past,

On all this world of men inherits

Their seal is set. 
As the same poet says in his preface to Hellas, "We are all Greeks."

$$
\text { * }
$$

*

*

*

*

*

It now remains to examine at what times, in what ways, and to what extent, our own English literature has been influenced by models so rich and virile. The points of contact have been numerous; the influence which has been felt has not always been felt in the same respects. At one time we merely borrowed some of the matter of Greek writing, some of its stories of mythology and history, some of its figures and similes, some fragments of its philosophy. At another time we have copied some of its forms of production, such as the epic form of Homer, the Pindaric Ode, the idyll of Theocritus. At another time we have borrowed its literary criticism, and either garbled and misapplied it, like Pope, or rightly assimilated it, like Matthew Arnold. It is possible also to adopt its matter, its form, its Hellenic principles of criticism, all together; and that is what so many of the best writers of to-day are, consciously or unconsciously, labouring to do.

We have, in fact, grown more and more dependent on Greece with every generation of our literature since the days of Chaucer. This may appear a paradox, but it is no more than the truth. Antecedently one might suppose that, with the progress of what is called civilization, and with the expansion of knowledge, the literature of the ancient Greeks must now have been left far behind, as a thing of remarkable interest, no doubt, but a thing which has performed its practical function, a nourishment 
which has been sucked dry. Yet the very contrary is the case. In verse Tennyson, Matthew Arnold, Browning, Swinburne, William Morris, in prose Newman, Froude, Ruskin, whatever may be their points of difference, or even of contrast, nevertheless agree in this, that they have all saturated themselves with Greek and the things of Greece, with its ideas, phrases, and stories, till their work is in greater or less measure dominated by what they have thence derived. A Greek scholar realizes this obvious fact at once, and with gladness. A reader to whom Greek literature has been a sealed book little thinks how many of the felicitous expressions which especially captivate him in his poets of the present age are conscious or unconscious echoes, paraphrases, or mere translations, of things written more than a score of centuries ago in pagan Athens or the Isles of Greece.

Let us take a brief preliminary survey.

To Chaucer there filtered through from Greece, by way of writers in Latin or Italian, crude notions of Greek mythology or Homeric stories. Of the style and form and historical perspective of Greek literature he had no manner of conception. To him Agamemnon and Ulysses were knights with squires; Troy was besieged as Paris might be. His debt to Greece amounts to little more than a jumble of fables at second hand.

By Spenser's day our English writers are beginning to realize how rich a store lies to their hand in the books of that Greek which men of Western Europe have once more begun to study. They learn 
some little of the tongue, and they borrow unsparingly its stories and its similes. But of the lesson of its style, its restrained art, they have still learned almost nothing. They are caring for little beyond the solids which it affords. The Faerie Queene is crammed with classical allusion, and with similitudes traceable to Homer and other Greeks; but hardly a vestige appears as yet of the Greek literary spirit of clear simplicity, self-restraint, severity of taste. The extravagance and tastelessness which so often tire and irritate the reader of the Faerie Queene are altogether alien from Hellenic art.

Pass onward for some generations, till we come to the days of Pope and Addison. The study of Greek is more careful and more widely spread, its history and mythology have dropped into truer perspective and proportion. Greek life, Greek thought, are somewhat better comprehended, though still far from well. Much that the Greeks have written has now become general property. Better still, criticism is alert. The principles of the Greeks have passed, in a garbled form, it is true, through Rome to France, from France to England. The English have awakened to the fact that what deserves to be said at all deserves to be said concisely and precisely. So far, so good. Perhaps we do not profoundly admire the spirit of the literature of the age of Pope and Addison. But we must perforce admire its great advance in polish of expression. As literature, it may fail from want of ideas, from thinness of its substance. In that respect it departs as far from the Greek ideal as it approaches near the Greek ideal in skill of execution. The aim of Greek literature is to express 
thought or feeling perfectly. But there must be a real thought or a real feeling to express. And this spontaneousness or compelling sincerity the school of Pope and Addison did not, in the main, possess. Yet it did invaluable work. It furnished a later generation, which had ideas and was not ashamed of feelings, with an improved conception of expression. The "Classical" school these writers have been called, but classical they distinctly are not, for to be classical is to express matter of sterling worth in a style for ever fresh. To utter brilliantly a nothing, an artificiality, or a commonplace, is not classical.

The Queen Anne and early Georgian school, then, so far as Greek literature is concerned, owe to it sundry healthy principles of style, not yet properly assimilated; they owe many allusions, better ordered and digested than in Spenser or Chaucer; but of its higher thoughts and deeper imaginings they exhibit little influence.

Let that century expire, and come to the generation of Wordsworth, Shelley, Keats, and Byron. In them we meet with rich ideas in plenty, and with abundance of exquisite expression. Wordsworth, Shelley, and Byron had studied Greek; Shelley read it all his life. Keats, who knew no Greek at first hand, but who had innate in him that part of the Greek spirit which, as he puts it, "loves the principle of beauty in all things," had steeped himself in Greek legend; he revelled in Greek mythology; he assimilated the Greek view of nature and at least the passion of Greek life. All the literature of this period is shot through and through with 
the colour of Greek myths, Greek philosophy in its widest sense, Greek ideas. It shows an advance upon the age of Pope; for now once more the matter is made of the first account, although the manner is duly cultivated to form its fitting embodiment. Expression is fashioned to great beauty in Shelley, Coleridge, Keats, and often in Wordsworth. But the matter is of the first moment. A great advance is this upon the perfectly uttered proprieties of Pope. Yet still the age of Shelley was less Greek than the following "Victorian" age. The magnificent outbursts of the "spontaneous" and "romantic" schools of the beginning of last century too often ended in extravagance of fancy and riot of imagination. The transcendental rhapsodizings of Shelley and the sensuous revellings of Keats lack the sanity and self-repression which we associate with the name of Hellas. But the aim of the last age has been to secure the perfect union of sane, clear, yet unhackneyed thought with sane, clear, yet unhackneyed phrase. This was the aim of Tennyson, as of Matthew Arnold. Even Browning aims at this ideal in his most perfect moments.

Now, if what has been said of the ages of Chaucer. Spenser, Pope, Shelley, and Tennyson respectively is true, it is anything but a paradox to assert that, generation after generation since Chaucer's day, we have been passing more and more under the domination of Greek thoughts and Greek literary principles, and that we are groping forward to a literary ideal which turns out to have been the ideal of ancient Greece.
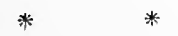

*⿻

米

*

* 
The full influence of Greece, then, was not felt all at once, nor in the same way and in the same respects.

Early English literature never came into direct contact with Greek books. Our old writers knew no Greek, for it is only since what is known as the "Revival of Learning" that the borrowing, whether of thought or style, has been at first hand. Nevertheless the debt was there, though the fathers of our literature were not conscious of it. Even King Alfred drew from Greek sources, though he knew no more of Greek than of baking cakes. When there was not a man from one end of England to the other who could properly read a Greek book, the men of England were neverthess deriving, in a mutilated form no doubt, but still deriving, philosophy and ideas from that ancient Greece which to them was shrouded in the darkness of distance and of a tongue unknown. We may endeavour to see how this came to pass.

In the first place, if our earliest writers could not read Greek, they could read Latin. If they could not read Homer, they could read Virgil; if not Sappho and Pindar, they could read Horace. The Latin literature was with them, in a considerable measure. It is true that in the Dark Ages many of the best works of Latin literature lay concealed, and that others were deliberately neglected. The taste of readers in those ages ran rather in favour of the later and inferior Latin authors. Nevertheless, Latin literature of considerable extent they did study and assimilate; and what was this Latin literature, speaking generally, but an avowed imitation or copy of Greek models? The Roman Virgil copies the 
Greek Homer, Hesiod, and Theocritus. The Roman Horace copies Sappho, Pindar, Archilochus, Anacreon. The Roman Plautus and Terence are practically plagiaries of the Greek Menander and his like. Latin literature is, in a very large degree, Greek literature borrowed, adapted to inferior taste, played upon like studies with variations.

When Rome became the mistress of the world, it aspired to greater glory than mere conquest can ever impart, to the glory of culture and the arts. It found these perfected in Greece, and it became the pupil and imitator of that country, just as England has at various times become the pupil of Italy or France. It would hardly beutoo much to say of Latin literature, as of Roman art, that most of what is vital and perennial in it comes from Greece, while its faults and shortcomings are chiefly its own. Those who possess Latin literature possess a body of Greek thought and Greek material, but lacking the sure Greek taste and the soul of spontaneity. Our English writers down to Chaucer were in this position. Even their Latin reading was unsatisfactory enough, but, so far as they practised it, they were drinking of Greek waters rendered turbid by Roman handling and adulteration.

King Alfred knew Latin enough to translate Boethius. The monks and scholars, who, till Chaucer's time, were the only writers, kept alive the reading of Latin literature. But, so far as the Greek was concerned at first hand, there was but one poorly equipped scholar here and another there in all the West of Europe. So little was it known that, even in Wyclif's day, it was necessary for that reformer 
in translating the New Testament to render from the Latin Vulgate, the Greek original being veritably "all Greek" to him. Chaucer, again, writes indeed of Greeks at Thebes and Troy, and refers to Aristotle and Greek authors; but his acquaintance with these is all at second hand, through Roman poets like Ovid and Statius, or even at third or fourth hand, through the literature of Frenchmen or Italians, who themselves derived from writers in Latin and not from the Greek originals.

This, then, is the first period and manner of Greek influence, an influence indirect and roundabout, exerted through the medium of Latin literature, in which the style and spirit of Greece had already been corrupted or destroyed.

The second manner of influence was still more roundabout. It came through the Saracens and Moors. When the Saracen power had reached its zenith and one caliph sat in state at Bagdad and another at Cordova, the Saracens felt what the Romans had felt, that, after all, it is culture and arts which give a nation nobility. In the eleventh and twelfth centuries in particular the Saracen kingdom in Spain flourished mightily in culture and learning. Early in the ninth century a caliph of Bagdad showed himself one of the most devoted fosterers of literature that the world has ever known. His Court was thronged with men of letters and learning; he lavished honours on them; he collected books from every source, and especially from Greece. When he dictated terms of peace to the Greek Emperor Michael he demanded as tribute a collection of Greek authors. 
Works of the Greeks on rhetoric and philosophy were particularly prized, translated, and commented on. But the learning of Bagdad meant also the learning of the Moors in Spain. In the eleventh and twelfth centuries the science of the Moors was sought by many western students who were not Moslems; and thus from Bagdad, round by way of Spain, there percolated to Italy, France, and England some knowledge of what classical Greece had thought and written. In particular, Averrhoes, a Saracen, translated Aristotle into Arabic; from the Arabic a Latin version was made. This version passed into general use, and the Aristotelean philosophy, which dominated, not to say tyrannized, over Europe for centuries, owes its access to Western Europe to the followers of Mohammed.

Thus far, until the Renaissance dawned in Italy, we find in Western Europe no acquaintance with Greek literature at first hand, but only so much knowledge of its contents as could be gathered from the Latin writers, who had recast it or plagiarized it, or from the Saracen writers, who had translated it in parts.

At last, however, the influence was to become direct. And first on Italy. As the Turks entered Europe, and gradually overran the empire of Greece, Greeks of learning made their way westward to Venice, Ravenna, Padua, Florence, Rome. After the year 1300 , or thereabouts, during the great age of Dante, Petrarch and Boccaccio, we find writers of Italy beginning to acquire some knowledge of Greek, and some insight into the rich literary stores which that 
language contained. Boccaccio learned the language from a native Greek; Petrarch took lessons from the same. One Italian here, and another there, essayed translations and imitations of Greek authors. In I453 Constantinople, the capital of the Greek empire, fell into the hands of the Turks, and Greece no longer existed. As a result, crowds of cultured Greeks streamed into Italy with books and manuscripts, prepared to teach for love or money, or from mere ardour and pride of patriotism. The Court of Cosmo de' Medici at Florence was readily opened to them, and all Italy was agog to learn whatever they could bring. The libraries of Rome and Florence were enriched with Greek manuscripts; and when, soon after, the printing press of Aldus at Venice was established, Homer or Aeschylus passed in the original into many hands, while translations of them came into many more. Greek teachers like Chalcondylas, Argyropoulos, and Lascaris have left their names to fame in Rome and Padua and Florence. The Revival of Learning had filled all Italy, and "learning" meant little but the literature of Greece; it became regular, almost inevitable, that the Italian man of letters should know Greek, and should steep himself in the writings of the Grecians. From Italy the study spread to France and England. Grocyn and Linacre at Oxford, Erasmus and Cheke at Cambridge, worked zealously to establish it against that opposition which always attends the disturbance of sluggish methods and musty privilege. The study was opposed by the "Trojans," and it was perhaps natural that these should cry out, in an ancient phrase, "Beware of the Greeks, lest they make you a heretic"; for already 
it was recognized that the revival of Greek learning meant the stimulation of all clear, and therefore progressive, intellectual activities.

By about the year I550-that is to say, just in time for Spenser, Shakespeare, Bacon, and their kindred-it had become usual for the Universities and the better schools in England to teach the elements of Greek; and there were not wanting ardent students, in those pre-examination days, to prosecute the study for themselves, and to find more than ample reward in the rich intellectual resources which lay revealed before them.

We have now reached the Elizabethan age of English literature. It is in this age that there came such an outburst of splendid creation in every form as the world has seen but once or twice. Sidney, Spenser, Shakespeare, Marlowe, Bacon, Hooker, Raleigh-drama, novel, lyrics, narrative poetry, essaywriting, philosophy, history-all these made new and magnificent efforts. And why? Not merely because at this epoch was born a genius like Shakespeare's, or a lofty intellect like Bacon's. The genius must have his opportunity; the intellect must have its materials. It was because the world was electrified with a current of new thoughts and new ideas, pervading and furnishing every mind. The "revival of learning" was something more than that name alone implies. It was also a renaissance, a " new birth," both of intellect and art. The spirit of Greece had breathed life into the dry bones of the valley of the West-European mind.

The writers of the Elizabethan age flung themselves about in the gardens and orchards of Greek 
literature with all the impatient appetite and reckless gaiety of schoolboys on holiday. They tore at the plots of Greek epics, plays, and histories; they plucked the similes and metaphors of Greece to "stick them in their hats," so to speak; so great was their joy in the strange fresh atmosphere of this luxuriant newly-opened paradise. Their scholarly knowledge of Greek as a language was too slight, their perspective of Greek life and thought too distorted, for them to catch the artistic style and spirit while they were catching the matter and the substance. Amazingly rich as Spenser is in imagery and melody, exhaustless as Shakespeare is in ideas, boundless as he is in capacity of seeing and feeling, no one will call either Spenser or Shakespeare a flawless artist, or say that either is free from extravagance or unevenness. In short, no one will concede to them the Greek spirit, which tempers imagination with self-restraint and unfailing sanity. The wide free range of mind they have; the tactful sense of proportion and seasonableness they too often lack. The influence of Greece, beneficent and large as it is, remains yet incomplete.

We must not, however, overstate the case. No one doubts that all this stupendous outburst obtained its chief stimulus and food from Greece. Nevertheless, when speaking of these Elizabethan times and of the new $\mathrm{G}$ reek studies which were being fostered by the Universities and the highest schools, let us not picture to ourselves every considerable writer of that time assiduously studying Greek books in their originals. That was far from the case. Their scholarship in that way was mostly but shallow. Shakespeare, 
we know, learned "little Latin and less Greek." We need not claim that, after his college days, Spenser went directly to his Greek Homer, any more than that Shakespeare went directly to his Greek Plutarch. What should be understood is that the matter, though not the manner, of Greek books was now fairly abundant in those writers' hands. The Elizabethan age was the age of translations, not always accurate translations, but generally translations of spirit. Chapman's Homer and North's Plutarch are household words. And, where there existed no English translation of a Greek book, there was almost certainly one in French or in Italian. Homer, for instance, translated by Filelfo, had come within English ken even before England had begun its own direct studies in Greek. Now, though a translation can do much, there is one thing it cannot do. It cannot convey the lesson of perfect art in style, least of all can it do this when the translator allows himself liberties. And therefore the Elizabethan writers have not yet gathered from the Hellenic mind its sober aesthetic principles.

Historically considered, the ancient Greeks too often become transformed, in the respective free translations, into contemporary Italians, or Englishmen, or Frenchmen. They present themselves to the mind in an alien dress, physically and mentally. They are, in fact, anachronisms. Agamemnon and Ulysses, instead of appearing as simple Achaean chiefs, become transformed into knights in armour, gallants with rapiers, kings in purple robes and crowns. They quote philosophy, or speak of sciences and instruments they never knew. 
In brief, in the Elizabethan age we have reached this-that the knowledge of Greek literature is no longer dependent on the Latin copies and plagiarisms of it, or on such driblets of philosophy as trickle through from the Saracens of Spain. It is derived, sometimes at first hand, but mostly from translations directly made in English, French, or Italian, from the Greek originals. Nor is this all. For among Englishmen who are training themselves to be the writers of the next generation there are growing up many to whom Greek itself, in all its nervous plasticity, is becoming a familiar tongue, and who will use no modern versions at the risk of distorting their taste and judgement. With this new generation will come the critical chastening of style which has hitherto been lacking.

Those who have never studied language as the classical languages are studied can scarcely hope to understand how vast is the difference between two educational results; on the one hand, of a painstaking study of that indescribable harmony of thought and word which constitutes style, and, on the other, of that superficial perusal of translations which supplies but coarse notions of the substance, notions as different from those of the scholar as the commercial plaster cast is different from the marble originals of Attic sculpture. Since the Shakespearean time our writers have become more and more scholars in Greek-witness Milton, Gray, Cowper, Shelley, among the poets-till, in our own days, it is difficult to meet with an author eminent either in prose or poetry who has not received a liberal training in the Greek language itself, and thence acquired a care 
of expression such as Greek models cannot fail to impress.

It may now be well to take for illustration one or two of the departments of literature-not necessarily of the first consequence-in which our debt to Greek is on the surface.

A striking form of Greek composition was the Pindaric Ode. Our English poets from Cowley to Swinburne have shown a marked fondness for this form. Cowley, Congreve, and Gray deliberately affect even the title Pindaric Ode, acknowledging the source of their inspiration and avowing the imitativeness of their work. The poet Mason speaks of "a Pindar's rapture in the lyre of Gray." Cowley, as has been mentioned already, is called on his tombstone the "English Pindar." Pope's Ode on St. Cecilia's Day is meant to be, even if it does not succeed in being, Pindaric in both shape and spirit. It is full, too, of allusion to things Greek, to the ship Argo, to the underworld, with Phlegethon and Sisyphus and Ixion, to the yellow meads of asphodel, to Orpheus and Eurydice. Dryden's Song for St. Cecilia's Day and his Alexander's Feast are imitations of Pindar and Simonides. Gray's Progress of Poesy is of the same stamp. When he circulated the poem in manuscript, he called it an "Ode in the Greek manner." His Bard belongs to the same category. Meanwhile the words which open the Progress of Poesy

Awake, Aeolian lyre, awake,

And give to rapture all thy trembling strings

profess a debt to Aeolis, the country of the lyric Sappho and Alcaeus. We must add Collins and 
Shelley to the list of those over whom Pindar has exercised his charm. Shelley's Ode to Liberty, with its panegyric stanzas on Athens, is at least as Pindaric as the avowed Pindarics of Gray or Cowley.

We have already referred to that rather artificial and not very important form of composition called the "pastoral," whether it be the "pastoral idyll" or the " pastoral elegy"-an idealizing picture of the shepherd's life, or an idealistic "shepherd's lament." We may here briefly revert to the subject.

Of this class we have in English literature such works as the Shepheard's Calender of Spenser, a manifest and avowed imitation of Virgil through the Italians. As, however, Virgil is but the pupil of Theocritus in this kind, it is to the Greek Theocritus that we are in the end brought back. Spenser's imitation is, indeed, anything but good. He mixes up "Fair Elisa, queen of shepherds all" with talk of Parnassus, Helicon, Pan, Cynthia and the nymphs (whom he calls "ladies of the lake"). Colin Clout, Cuddie, and Hobbinol are found side by side with Tityrus and invocations to Calliope. Moreover he justly incurs the reproach of Sir Philip Sidney by his affectation of an archaic language for his shepherds, a language which never was on land or sea. Says Sidney, "that same framing of his style to an old rusticke language I dare not allow; since neither Theocritus in Greek, Virgil in Latin, nor Sannazaro in Italian, did affect it." We have also the youthful Pastorals of Pope, in which the poet begins by announcing his studied imitation:

Fair Thames, flow gently from thy sacred spring, While on thy banks Sicilian Muses sing; 
that is to say, the Muses of Theocritus of Sicily. He even appends notes to show what lines he has especially copied. We meet always the familiar Greek characters, Daphnis, Strephon, Alexis, Lycidas, and Thyrsis. Like the pastorals of Spenser, they are purely and confessedly artificial; they are anachronisms, carelessly mixing modern and antique ideas and associations. When Theocritus wrote pastorals in ancient and sunny Sicily he wrote, as we have remarked, of what lay within the range of conceivable possibility. Pope relegates the pastoral to a fictitious golden age in a purely fictitious golden land.

No one nowadays is likely to set any high value upon such eclogues as Pope's Pastorals. Even Spenser's Shepheard's Calender is rather talked of than read. Sidney's Arcadia has had its day. But it is otherwise with a nobler species of composition which arose out of pastorals, to wit, the pastoral elegy. Theocritus and his disciples, Bion and Moschus, all compose poetic laments for a lost shepherd, either an imaginary Daphnis or a real friend lately dead. To this original conception we owe certain English poems which we could not spare. They include the Lycidas of Milton, on the death of his friend King, the Adonais of Shelley, on the death of Keats, the Thyrsis of Matthew Arnold, on the death of Clough. The Daphmaida of Spenser was apparently the first of such elegiac pastorals. Another is his Astrophel, "on the death of the most noble and valorous knight, Sir Philip Sidney." Dryden, too, did not disdain to write a pastoral elegy on the death of a supposed Amyntas, in which 
he sings his dirge in the good old style of the Sicilians. A more refined, more distant and subtle development from the same original is Tennyson's In Memoriam. Finally we may take leave of this rural style with brief mention of the fact that Tennyson's Enone is in essence a pastoral idyll, inspired by the second of Theocritus.

We may also turn again to literary criticism. It is a significant thing that, no sooner had Sir John Cheke studied Greek and become its first regular professor at Cambridge, than he forthwith published maxims on the avoidance of bombast and pedantry in style. He had been to the fountain heads of criticism, to the Greek of Aristotle and Longinus. From that day down to the days of Matthew Arnold, in " essays in criticism" Greek principles have everywhere been theoretically worshipped, however much they may have been violated in practice. Following on the revival of Greek learning came a rage to discuss the rationale of the poetic art, as well as to exemplify its various forms. In the Elizabethan age Puttenham wrote on the Art of English Poesie; Sidney composed a Defence of Poesie. Later on Dryden put forth a prose treatise Of Dramatic Poesie, and the Earl of Roscommon an Essay on Translated Verse. Dryden expressly declares that true criticism began with the Greeks in the Poetics of Aristotle. He says:

Such once were critics; such the happy few Athens and Rome in better ages knew. The mighty Stagirite first left the shore, Spread all his sails, and durst the deep explore;

He steered securely, and discovered far, Led by the light of the Maeonian star. 
Pope followed with an Essay on Criticism, Shelley contributed a critical Defence of Poetry; and since that date books, essays, articles have showered upon us, in one and all of which we are assured with increasing urgency that the true principles of literary art are the principles of Athens, the principles of Greek literature at its best.

We may now leave types of literary creation and deal with individual authors. It would require a whole book for each of the greater names, if we sought to discover how much of matter or form each owes directly or indirectly to Greece. Mr. Churton Collins has written one such book on Tennyson. Here our survey must be but very superficial, as befits an introduction to the study.

Of Spenser's Shepheard's Calender, Daphnaida, and Astrophel something has been said. It remains to observe that his Faerie Queene is but one mass of scenes, events, and images borrowed from sources in Italy and Greece, and that the hint for the whole design was suggested by his studies in Aristotle; for he says, "I labour to pourtraict in Arthur the image of a brave knight, perfected in the twelve moral vertues, as Aristotle hath devised." Of the Greek manner, its proportion and moderation, Spenser has unhappily learned little or nothing.

Shakespeare was, in one sense, no Grecian. Sundry of his Roman plots, Coriolanus and Antony and Cleopatra for example, he takes from North's translation of the Greek Plutarch; a certain amount of Greek mythology and history reveals itself incidentally; but he owes less to Greece and more to his own 
genius acting upon desultory reading, than other writers of the time or since. Dryden, indeed, in his adaptation of Troilus and Cressida makes him say:

Untaught, unpractised, in a barbarous age,

I found not, but created first, the stage;

And if I drained no Greek or Latin store,

'Twas that my own abundance gave me more.

But this is hardly the truth. One immensely important thing Shakespeare did owe to Greece, through scholars who were his own immediate predecessors, and that was the general shape and form of the poetic drama.

Milton was an accomplished Greek scholar. It has been al ready pointed out that his greatepicis descended from Homer, and his Lycidas from Theocritus. His Samson Agonistes was deliberately built-though not with complete success-upon the traditional framework of Greek tragedies, and Milton himself leaves it to be judged by those who are " not unacquainted with Aeschylus, Sophocles, and Euripides." His Ode on the Morning of the Nativity is intended to be Pindaric. But the most palpable advance made by Milton on his predecessor Spenser is in the chastening of his style. The principles of that style Milton derived at first hand from his Hellenic models. He has learned how to use ancient material, how to adapt ancient thoughts, ancient expressions, how to sink them and imbed them in his own, not merely how to overlay or fancifully decorate his own with them. The texture of Milton's verse is shot through and through with colours borrowed from the Greek; it would often be quite possible to resolve a series of his lines into components which are imitations and 
quotations. But he has made them all so much a part of himself that we may often pass by his loans, as we never can those of Spenser, unconsciously.

Dryden owns himself an obedient follower of the Greeks. His ode To the Memory of Mrs. Anne Killigrew, like his St. Cecilia's Day and his Alexander's Feast, is Pindaric. His admiration for Pindar was indeed peculiarly ardent. He speaks of him as "the inimitable Pindar, who stretches on pinions out of sight, and is carried upward, as it were, into another world." Of his literary criticism we have spoken; there was a time when he conceived the idea of translating Homer, and he did in fact attempt versions of various writings of Greek poets.

Pope was but an indifferent Greek scholar at first hand; he did indeed freely translate and recast Homer's Iliad and Odyssey by the help of his little Greek and a translation in French, but he never entered into the spirit of Greek life or penetrated to the precise secret of Greek style. Nevertheless, he makes great pretensions to follow in the footsteps of the Greek masters. One thing he did catch-the vigour and fire of Homer; and Pope's Iliad is still the English Homer commonly read in these days, although Chapman had preceded him, and Cowper, Derby, and Morris have made their more or less faithful renderings since. And yet the book is far too much Pope to be Homer. Of the Pastorals and the Essay on Criticism all has been said above that need be said for our purpose. We have only to add that his burlesque heroics, the Rape of the Lock and the Dunciad, had their prototype in the heroicomical poems of Greece, the Battle of the Frogs 
and Mice and the Margites, compositions which were once ascribed to Homer, and which Pope professed to have in mind.

Gray was a scholar of rare attainments in both the language and the literature of Greece. Hence, in no inconsiderable measure, his self-critical spirit. His aim, as stated by himself, is at "extreme conciseness of expression, yet pure, perspicuous and musical." As a poet he suffered from constitutional shortcomings. He is without profound imaginings or ecstatic sensibilities; but his beauties are no less undeniable, although of the sort which are mainly acquired from training. No one can fail to admire the perfect technique of his stanzas. It is doubtful, however, whether any but a Greek scholar can perceive the skill with which he has combined a mosaic of reminiscences of ancient writers into stanzas of perfect English. His Progress of Poesy and his Bard are plainly modelled on Pindar, but even his most beautiful individual expressions are sometimes but translations from the Greek. Said the Greek Phrynichus: "The purple light of love shines on her flushing cheeks." To this Gray owes his

O'er her warm cheek and rising bosom move

The bloom of young desire and purple light of love.

Of his enthusiasm for Greece we may judge from a passage in the Progress of Poesy:

Woods, that wave o'er Delphi's steep,

Isles, that crown the Egaean deep,

Fields, that cool Ilissus laves,

Or where Maeander's amber waves

In lingering lab'rinths creep;

How do your tuneful echoes languish - 
Mute, but to the voice of anguish?

Where each old poetic mountain

Inspiration breath'd around:

Ev'ry shade and hallowed fountain

Murmur'd deep a solemn sound:

Till the sad Nine in Greece's evil hour,

Left their Parnassus for the Latian plains.

* Swift's most popular work, Gulliver's Travels, derives its hint from Lucian's True History, and all that peculiar vein of humour which runs through the Tale of a Tub and the Battle of the Books, is, consciously or unconsciously, the parallel of the characteristic irony of the same Lucian.

Of Shelley's debts to Greece one can hardly estimate the amount. Says he himself: "The poetry of ancient Greece and Rome and modern Italy and our own country has been to me like external nature, a passion and an enjoyment." During his travels in Italy " the Greek tragedies," says Mrs. Shelley, "were his most familiar companions in his wanderings, and the sublime majesty of Aeschylus filled him with wonder and delight." We find him reading Homer, Hesiod, Theocritus, Thucydides, Aeschylus, Plutarch, Plato; he even translates portions of these; he steeps himself to the lips in the literature of Greece. His own soul and genius were by nature akin to those of Plato, and his training lent to his genius clear capacity. Among those of his works which most manifestly bear the Greek impress are the lyrical drama of Hellas-which, he says, was suggested by the Persae of Aeschylus-and the drama of Prometheus Unbound, which is meant for a sequel to the Prometheus Bound of Aeschylus. Not 
that his drama of Prometheus is fashioned wholly like the Greek; its architecture is less simple, its character is more rhetorical, more ornamented, more metaphysical. But it owes its whole existence to the fact that Shelley lived so long in a world of Greek literature, a world very remote from that in which he moved and had his being. His Adonais-

1 weep for Adonais-he is dead!

$O$ weep for Adonais! though our tears

Thaw not the frost that binds so dear a head!

is an echo of Theocritus, his ${ }_{3}^{-}$Ode to Liberty an echo of Pindar, his Epipsychidion an outcome of Plato. His enthusiasm for Greece may be gathered from his Hellas:

The world's great age begins anew,

The golden years return;

The earth doth like a snake renew

Her winter weeds outworn. . . .

A brighter Hellas rears its mountains

From waves serener far;

A new Peneus rolls its fountains

Against the morning star;

Where fairer Tempes bloom, there sleep

Young Cyclads on a sunnier deep.

Keats never learned the Greek language. But he was read, as perhaps never Englishman was read before, in Greek legend and mythology. He devoured Lemprière's Dictionary. His greatest poetry -his chief odes, as well as his Hyperion and Endymion-is based on subjects thence acquired. The manners and characters of Greek divinities pervade his writings. In heart and soul, in sensuous enjoyment of life, he was himself a pagan Greek. The 
life of the ancient world, idealized, was the world of his choice. Above all he loves the sounds uttered

In Grecian isles

By bards who dicd content on pleasant sward,

Leaving great verse unto a little clan.

$\mathrm{O}$ give me their old vigour!

"Therefore," says he,

'Tis with full happiness that I

Will trace the story of Endymion.

The very music of the name has gone

Into my being.

Had he studied Greek as language, and Greek as style, he would, we may believe, have avoided earlier his one great fault, the fault of excess, extravagance, and riot. What Keats thought of the great Greek writers whose Greek he could not read, may be gathered from his lines to Homer:

Standing aloof in giant ignorance,

Of thee I hear, and of the Cyclades,

As one who sits ashore and longs perchance

To visit dolphin-coral in deep seas:

and from those On first looking into Chapman's Homer:

Much have I travelled in the realms of gold, And many goodly states and kingdoms seen; Round many western islands have I been, Which bards in fealty to Apollo hold.

Oft of one wide expanse had I been told, That deep-brow'd Homer ruled as his demesne;

Yet did I never breathe its pure serene

Till I heard Chapman speak out loud and bold.

Then felt I like some watcher of the skies, When a new planet swims into his ken;

Or like stout Cortez, when with eagle eyes He stared at the Pacific-and all his men 
Look'd at each other with a wild surmiseSilent, upon a peak in Datrien.

The name of Byron is at once associated with enthusiasm for Greece. True, it was modern Greece, but the only reason for that warm affection lay in the fervour of his admiration for the Greece of old. That "land of lost gods and godlike men" was to him a sacred land. Everyone knows his outburst touching the "isles of Greece." But not everyone perceives how profoundly the mind of Byron had been stirred by the ancient ideals and influences. Not everyone perceives that his Manfred is an unmistakable echo of Aeschylus' Prometheus, in the tone and pitch of its composition, in the firmness of the central character, in his mental suffering, in the tremendous solitude, in the supernatural of the surroundings. Yet Byron is not one whom we may quote as typifying any great direct and salutary effect of Greek upon either his style or his matter. $\mathrm{He}$ is too slipshod in the one and too romantic in the other. But his ardour for the land of great literature is beyond denying:

The isles of Greece, the isles of Greece!

Where burning Sappho loved and sung,

Where grew the arts of war and peace,

Where Delos rose, and Phoebus sprung:

Eternal summer gilds them yet,

But all, except their sun, is set.

The Scian and the Teian muse,

The lover's harp, the lover's lute,

Have found the fame your shores refuse:

Their place of birth alone is mute

To sounds which echo further west

Than your sires' "Islands of the Blest.' 
And where are they? and where art thou,

My country? On thy voiceless shore

The heroic lay is tuneless now-

The heroic bosom beats no more?

And must thy lyre, so long divine,

Degenerate into hands like mine?

During the last fifty years the study of Greek literature has been set on a new basis. A collection of ill-digested matter no longer suffices. Greek is taught more understandingly and more deeply. First comes a patient observant study of the language; afterwards, in years of maturity, are estimated the qualities of the thought and of the style; these are set in clearer lights, and turned to a direct application. Landor is the first modern in whom this sort of study reveals its effects. His Greek devotion to classical associations, to ideal beauty, his Greek aversion to the mysterious, his love for clearness and purity of outline, appear cold to many a reader. He is too pellucid, of too delicate a preciseness, they imagine. But Landor does not displease through these qualities, which are virtues. His coldness is constitutional. However that may be, his imaginary dialogues, imitated from Plato, and the poetry of his Hellenics, show the Greek influence in a fuller form than we have met with hitherto. Since Landor's day our literature is pervaded with Greek ideals: it aims at Greek style, and often it attains fairly to its mark. We need not deal with matter so voluminous as that of Browning, nor with a style so inconsistent. But Browning's love of Greek is matter of fame. Has he not translated the Agamemnon of Aeschylus, the Alcestis and the Heracles of Euri- 
pides? Nor need we deal with the poetry of Swinburne. It is enough to point out that the Atalanta in Calydon is in spirit intensely Greek, and that its most famous speech is a translation from Euripides.

From William Morris we have a translation of the Odyssey; he has written the Life and Death of Jason and the Earthly Paradise, and both of these owe almost everything-their matter and the charm of their manner - to the Iliad and the Odyssey, to Apollonius, and to the Greek tragedians.

To two of the best and purest poets of our age Greece has supplied the very breath of literary life. One is Matthew Arnold, the other is Tennyson. Matthew Arnold as critic, Matthew Arnold as poet, is equally Hellenic. $\mathrm{He}$ has been charged with "an air of aristocratic selectness and literary exclusiveness." The art of Pheidias is open to the same objection. What really marks the style of Matthew Arnold is his reasoned simplicity of taste, his cultivated appreciation of the delicate aroma of words and the poetical atmosphere of thought. Like Tennyson, he has a true eye for beauty, grace, and congruity of effect. He compasses the "liquid clearness of an Ionian sky." It may be that he lacks abandon. He may not feel with the poignancy, or soar with the boldness, of the greatest creators. But, artistically considered, he is as nearly perfect as it is given to man to be. His poetic style is, indeed, almost too perfect for the general. When he says

Or where the echoing oars

Of Argo first

Startled the unknown sea.

he is using the only two adjectives which the place 
required, and which it truthfully admits. They are exactly the two epithets which a Greek might put. Yet, no doubt, the untutored mind asks for something more assertive, something which will cut more sharply or press more heavily into the unready imagination. Than Mycerinus, than Sohrab and Rustum, than Philomela, Thyrsis, or The Strayed Reveller, one can find nothing more absolutely Greek in point of execution, though one may know Greek passages which stir profounder emotional depths.

Tennyson's debts to classical authors have been treated by Mr. Churton Collins in a monograph. That critic is right in saying that the knowledge of a scholar is requisite to appreciate Tennyson fully, however much he may be appreciated by those who are no scholars. No man has ever been better read in previous poetry than Tennyson, and no man has known better how to assimilate what he found, or has possessed a surer tact and taste in using it. With Tennyson the Greek matter is, as with Milton, imbedded in his own, not overlaid. Greek forms of verse are moulded to his purpose. The Greek style, describing what is luminously seen in a few luminous touches, is ever conspicuous. He neither tries to disguise his borrowings, nor does he obtrude them. When he says, "for now the noonday quiet holds the hill," he is translating Callimachus; when "the charm of married brows," Theocritus; when "shadowy thoroughfares of thought," Sophocles; when" "sitting well in order smite the sounding furrows," Homer. His device of making the sound answer to the sense, as in 

BRIEF CONSPECTUS OF GREEK LITERATLRE.

\begin{tabular}{|c|c|c|c|c|c|}
\hline 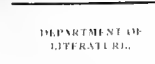 & 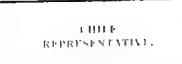 & mole. & 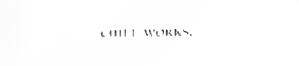 & 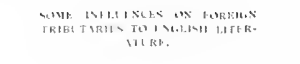 & 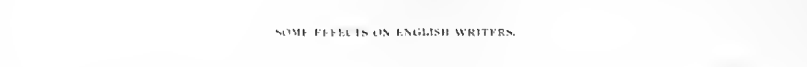 \\
\hline lipir Virne & IWWik & 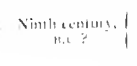 & 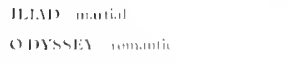 & 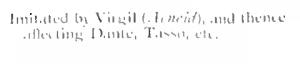 & 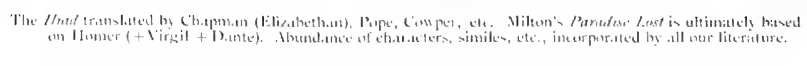 \\
\hline 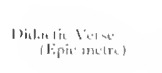 & 111: $4(0) 11)$ & 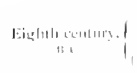 & 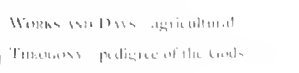 & 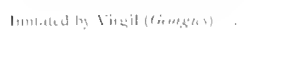 & 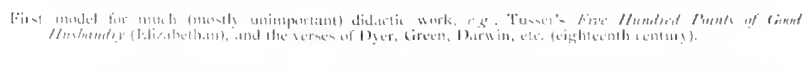 \\
\hline l.116 b1140 & 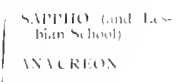 & 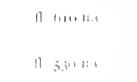 & 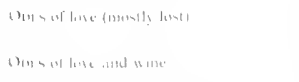 & 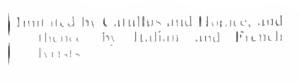 & 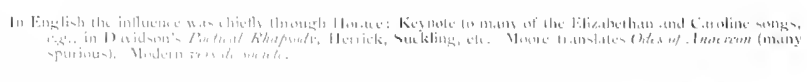 \\
\hline & 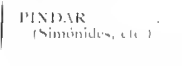 & 11. +..., in. & 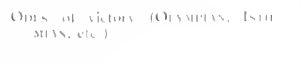 & 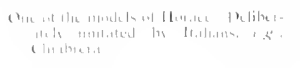 & 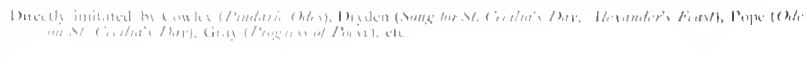 \\
\hline 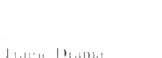 & 11: 4 C11Yi.1 & 11. $+4 n+5^{i x}+3$ & 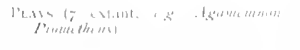 & 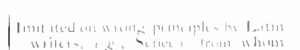 & 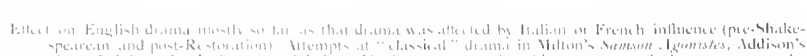 \\
\hline 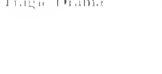 & 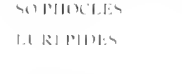 & 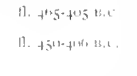 & 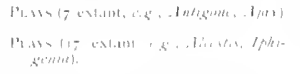 & 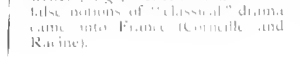 & 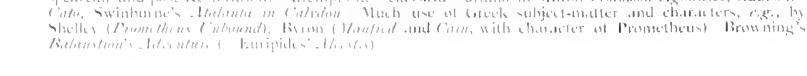 \\
\hline & 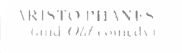 & $n+\cdots+k+16$ & 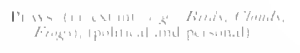 & & \\
\hline 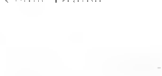 & 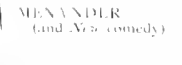 & 11. $; \ldots \ldots, 1$. & 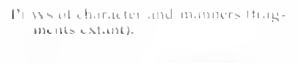 & 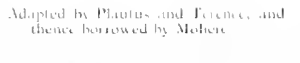 & 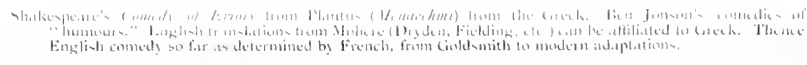 \\
\hline & 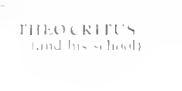 & $\| z-\ldots$, is.t. & 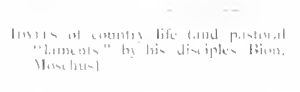 & 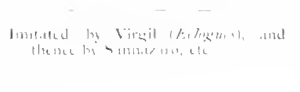 & 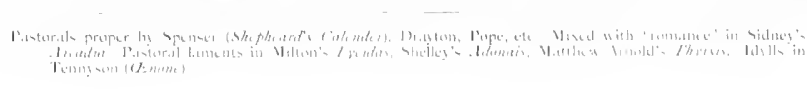 \\
\hline 11. & 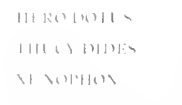 & 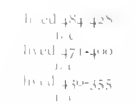 & 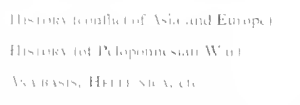 & 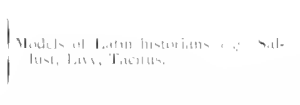 & 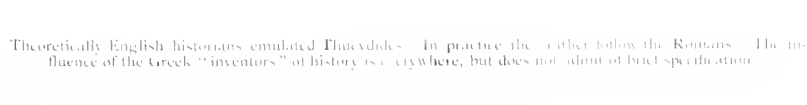 \\
\hline 1, & 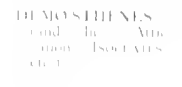 & 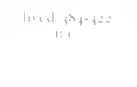 & 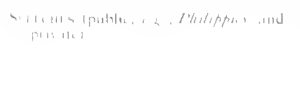 & 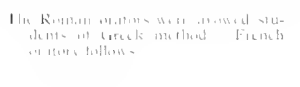 & 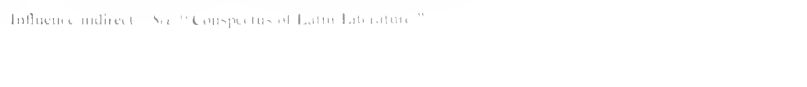 \\
\hline \multirow[t]{2}{*}{$1 \cdots \cdots=$, in } & 11110 & 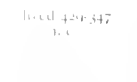 & 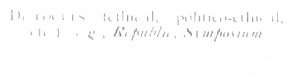 & 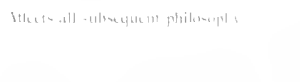 & 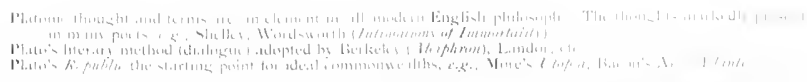 \\
\hline & |kいかり| & 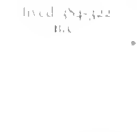 & 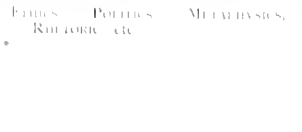 & 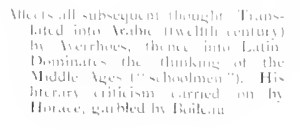 & 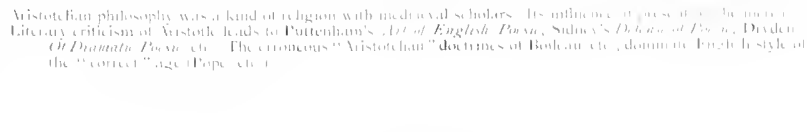 \\
\hline \multirow[t]{2}{*}{ 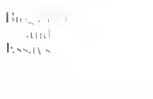 } & $11.11 \mathrm{k}(1)$ & $13 \times 13, \ldots$ & 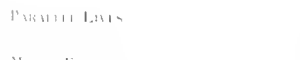 & 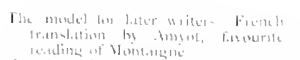 & \multirow[t]{2}{*}{ 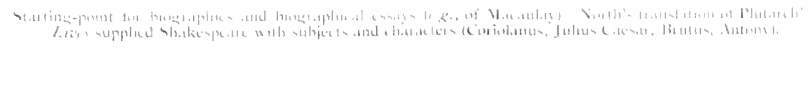 } \\
\hline & & & Well of lim & 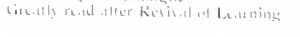 & \\
\hline 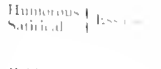 & $1.1(1+1)$ & 1. 1. 1., tho & 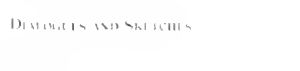 & 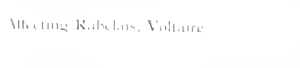 & 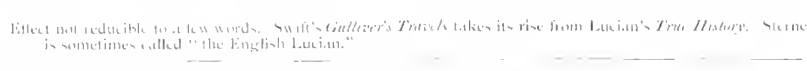 \\
\hline Fillke & twow & 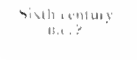 & Fusu: & 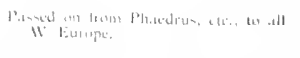 & 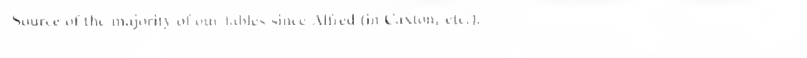 \\
\hline 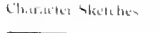 & Theuplactitur & 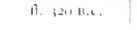 & 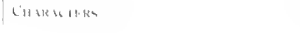 & Imolad by I... Brmice. & 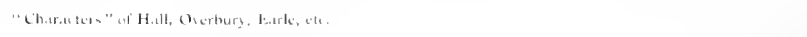 \\
\hline
\end{tabular}




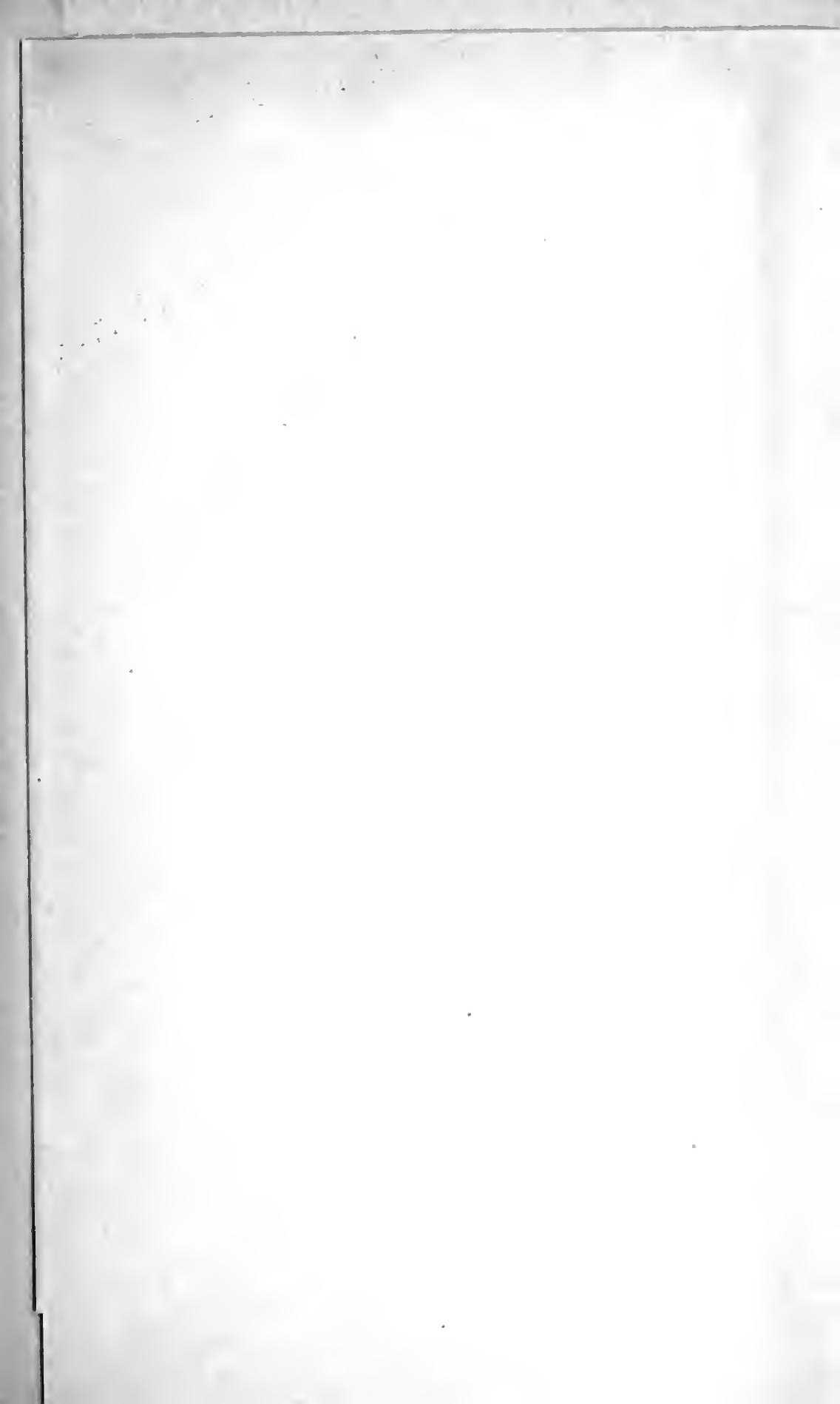


SYNOPTICAL VIEW OF RELATIONS

OF GREEK LITERATURE

WITH ENGLISH.

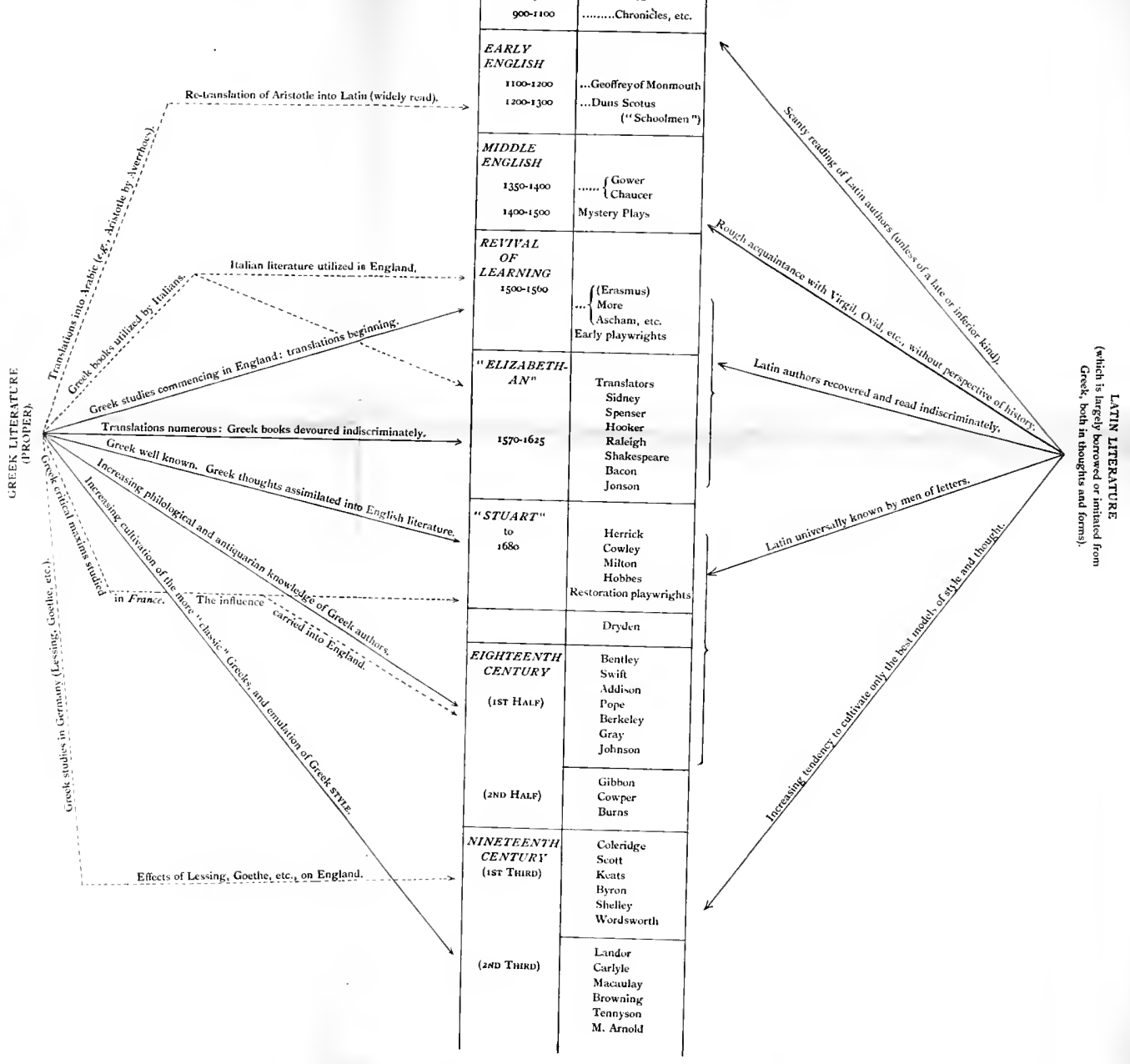




\section{INFLUENCE ON MODERN POETRY 69}

I heard the water lapping on the cras,

And the long ripple washing in the reeds,

is a common device of the Greeks. In point of form his Enone is modelled on Theocritus; his Ulysses and his Tithonus are framed after the soliloquies in Greek plays. His Lotus-eaters gets its matter from Homer, Bion, and Moschus. Everywhere we meet hints and reminiscences of Simonides, or Pindar, or Theocritus, or Anacreon. But these are all incorporated, amalgamated in a body of work which is wholly in keeping with them in taste, in tone, in diction--in short, in style.

This age of ours, to put it briefly, has been an age of stylists, of artists who work on principles derived from their education in Greek, and their love, which every scholar feels, of that glorious and undying literature. 


\section{LATIN LITERATURE AND ENGLISH}

THE fashion of treating Latin literature as of all

1 importance to English is passing away in the better understanding of things. It is true that the knowledge of Latin has been always more widely spread than the knowledge of Greek, and that our speech is more deeply tinged with Latinity. Yet Greek literature is the source and origin of almost all that is best in Latin, and its influence to-day is far more vital. Let it be added that, while in point of matter and thought Latin borrowed unsparingly from Greek, in point of style its principles were less sound or consistent.

Nevertheless, Latin literature is of immense importance. We may think of the prodigious historical significance of the pagan Roman Empire, and then of the prodigious spiritual significance of the Christian Roman Church. We may think of the impress that has been left on all Western Europe by these, and remember that the language of each is Latin. The necessity of not neglecting the mere language is obvious. But we are here concerned with Latin literature, of which the language is but the vehicle.

Where does Latin literature begin and end? 
Writing in Latin has not ended yet. But we shall for the present confine ourselves to the Latin works of pagan Rome, in the days when Rome can fairly be called a nation of tolerably homogeneous life and pursuits. Though the writings of Tertullian, Lactantius, Jerome and Augustine, in the third and fourth centuries, are undeniably Latin, and literature also, we can on this principle draw a tolerably clear line against them. Similarly the later poets, such as Ausonius, Claudian, and Boethius, lie outside the scope of the present chapter.

From the third century в.c. onwards, the Latinspeaking Romans, beginning as a mere clan in central Italy, spread their empire gradually over the peninsula, over France, Spain and Portugal, over Great Britain to the Grampians, across the Rhine, along the Danube, over modern Turkey and Greece, over Asia Minor and Syria to the river Euphrates, over most of Arabia, Egypt, and all the southern coast of the Mediterranean. In Spain and Portugal, in France, and in Roumania they planted colonies and settlements, till the languages of those countries actually became Latin; dialects, no doubt, but Latin. Over all this empire Latin literature spread with the spreading of control and settlement, and in the first century of our era it was as natural for a Latin writer to hail from Spain as from Rome. Persons no less than Seneca, Lucan, Quintilian, and Martial are Spaniards from towns later known as Cordova, Calahorra and Bambola. Subsequently Africa (Tunis) and Gaul have their distinguished representatives.

Considerations like these should make it clear how 
vast an influence Latin literature must have wielded both directly and indirectly. The modern languages of France, Spain, Portugal, Roumania, and Italy are various continuations of the Latin; and France, Spain, Portugal, and Italy, despite all historical changes, have been neither able nor desirous to shake off the guidance and impulses of Latin literature. This is one reason why it is the French and Italians who find their chief study in Virgil and Horace, Cicero and Seneca, whereas the Teutons, exerting a greater freedom of choice, more distinctly recognize the superiority of Homer and Sappho, Demosthenes and Aeschylus.

Needless to say that the people which could build and govern such an empire and hold it so long together must have been a people of strong innate quality. It need be no surprise that it was hardly an imaginative or artistic quality. It is, indeed, scarcely open to dispute that the old Roman and his kindred Italian tribes were marked by a comparative lack of fine imagination. Not only in war and politics, in legal and political institutions, but in intellectual culture they were a most practical and literalminded race.

We are apt, in looking at the modern Frenchman or Italian, to commit two large errors. Because they frequently appear excitable in temper and demonstrative in gesture, we incline to put them down not only as passionate, but as profound in sentiment, feeling, and imagination. Yet, in point of fact, still waters run deep, here as elsewhere. The second error is greater still. We judge the old Latin stock from the so-called "Neo-Latin" peoples, or 
those who speak the neo-Latin tongues. $Y$ et in many cases the "Neo-Latins" have but a comparatively small infusion of Roman blood still running in their veins. In some cases their forbears must have had none at all.

We can only judge the old Latin race, as especially embodied in the Roman, from its literature, its history and its institutions. From these we gather that it was a stock excellent for great ideals in the way of conquering and administering, a people of admirable commanders and engineers and jurists, a practical people, but a people not distinguished by brilliance of fancy, great delicacy of taste, notable depth of imagination or poignancy of feeling. Roman literature, left to itself, would, we may believe, have proved a very solid and rather heavy thing. The Latin language is like the Roman people. It is a language of great logical method and strict system of structure. As languages go, it is unusually free from idioms in the proper sense of the word. It is distinctly a solid and stately, but distinctly not a flexible, speech.

And yet, despite the innate character of the Latin stock, and the unyielding nature of the language, Latin literature is not so eminently practical and massive as we might expect.

For this there are two reasons. The one is that a large number of the chief writers of Latin literature are not themselves of unmixed Latin birth; they possess Celtic blood, or Greek blood, or some other non-Roman strain. Virgil came from Mantua, Catullus from Verona, Horace from Venusia, and other writers from other northern, southern, or even 
Spanish towns. The second reason is that, before Roman literature had properly earned the name, it had come into contact with the fully developed art of Greece, both Attic and Alexandrian, and forthwith became a literature of imitation. Feeling its limitations, the Latin genius submitted its own tendencies to the correction of a people whom it instinctively recognized as superior in this domain. But here an important qualification must be made. It cannot be too much insisted upon that Latin literature hardly rose at all till Greek literature was far decayed. Unhappily, when the Roman writers set about imitating their masters, they exploited, it is true, the matter or substance of anything Greek, and of any period, but the style and form which they affected were rather those of the later and inferior Greeks of Alexandria, not those of the perfect earlier masters of Attica and Ionia. It is in any case easier to imitate what is affected or "loud" or artificial than what is simply and naturally strong and beautiful.

Latin literature, in the sense in which we are to treat it, may be divided into three main periods. The first is that of immature art, of vigorous but ill-disciplined imitation of Greek models, of growing mastery over language. It is a period of preparation, the "iron age," corresponding roughly to the period of English literature before the Revival of Learning. The date of this epoch is from 250 to 8o в.c., and it embraces the best days of the republic. During all this time the literature, rough and poor as it was, was sincere enough. It was meant for the people and for a purpose. For us, 
however, it contains little of any consequence besides the comedies of Plautus and Terence.

The second period is that of highest excellence in prose and poetry, the age of Cicero, Lucretius, Catullus, Sallust, Caesar, Livy, Virgil, Horace, and Ovid. This is the "golden age," and may be dated from So B.C. to A.D. I4, a period during which the republic was passing into an empire, and when great men played their parts in great historical dramas; men like Sulla and Pompey, Julius Caesar, Antony, and Augustus. The latter half of this period, which extends from 30 B.C. to A.D. I4, and includes the names of Livy, Virgil, Horace, and Ovid, coincides with the rule of Augustus, and is therefore called the "Augustan" age. In other words, the Augustan age is the second half of the "golden" age. It is from So B.C. to A.D. 14 that Latin literature and the Latin language are at their highest degree of perfection. But, unhappily, at least during the second half, it is also a time when writers and readers are coming more and more to form a special literary class, which stands far aloof from the great public and its urgent or spontaneous interests.

The third period, the "silver age," is that of the despotic and often tyrant emperors, when freedom of speech no longer existed, when the autocrat, a servile aristocracy, and a vicious populace occupied the capital. At this date literature is but a forced product without real motive or inspiration. It is characterized by declamation and rhetoric, by smart epigram, by cynicism and satire, by clever expression. Such is the period of Seneca, Lucan, Martial, 
Tacitus, Pliny, Juvenal. It may be put down roughly as extending from A.D. I4 to the year 150.

These three epochs are peculiarly well defined; they are universally recognized, because so conspicuously recognizable.

* * * * * * * *

The first real incentive to literature among the Romans sprang from the contact into which they came with the Greeks of southern Italy and Sicily when their conquests reached so far. This was in the third century в.c. Until the Greek influence was strongly felt, we meet only with a series of rude records, or of uncouth and clownish verses of a satirical or farcical sort. From the rude records there began to develop themselves histories and epics; from the farces and satirical verses were destined to come the drama of tragedy and comedy and the literary satire; this, however, did not occur till the communication with Greece was full and close, and Greek material at hand to be utilized.

The first branch of Latin literature with which we need deal is the drama of comedy and tragedy. Practically this limits itself to the popular comedy of Plautus and Terence in the "iron" age, and the artificial and rhetorical tragedy of Seneca in the "silver" period.

Titus Maccius Plautus, who flourished about the year 2 ro в.c., and Publius Terentius, a generation later, are more nearly allied to each other than are Shakespeare and Ben Jonson. It is only the special student of literature who need be concerned to elaborate the full distinction between them. Plautus has the more of broad and boisterous fun and drollery, 
Terence has the subtler humour and the more artistic style and architecture. But both alike borrow plots and even dialogue wholesale from those Greek comedians of whom Menander is a type. They both adapt Greek plays, just as English playwrights once adapted Molière, and recently adapted Sardou. The Latin adaptations, however, were of quite undisguised eloseness, if not of positive servility. Whereas our playwrights seek to make their adaptations entirely English, Plautus and Terence did not seek to make theirs entirely Roman. It is true that their plots were based on real life, but it was a Greek life and not a Roman life. The scene was always in a Greek city. Imbecile fathers duped by spendthrift sons, jealous husbands outwitted and stultified, cunning and unscrupulous slaves playing the part of dei ex machina, armies of cooks, confidantes and nondescripts-these things, which appear monotonously, are not really Roman. Those who read the earlier plays of Molière generally grow somewhat weary of the clever valets, the Mascarilles, of the dupes, of the Sganarelles, and of the conventional tricks upon parents and husbands. The truth is that Molière, at this stage of his eareer, in imitating or adapting Plautus and Terence, was almost as far from the real life of Paris in his own day as Plautus and Terence were from the real life of Rome. Les Fourberies de Scapin is as distinet and as unconvincing an adaptation of the Phormio of Terence as Shakespeare's early Comedy of Errors is of Plautus's Menaechmi.

Now it is a noteworthy fact, as illustrating how doubly exotic a thing Latin literature was, that 
neither Plautus nor Terence was a true-born Roman. Plautus was a countryman of Umbria, Terence was an African of Carthage. Yet it was these two who remained the only considerable writers of Latin comedy, and the whole of their work was adaptation, free translation, or guileless plagiarism.

To our subject these writers are of no small account, in virtue of the fact that they were the progenitors of Italian comedy, thence of Molière, and, from Molière, of our own comic stage of the seventeenth, and the earlier and greater part of the eighteenth, century, the ages of Congreve and Farquhar, and of Fielding and Sheridan.

Tragedy, the other and nobler half of drama, took its rise in Latin literature as early as the year 240 B. C. ; but the obscure names of Andronicus (who, as usual, was not a genuine Roman, but a Greek) and of Naevius (who likewise was not a genuine Roman, but a Calabrian) need not here detain us. The one considerable personage in the whole history of the Latin tragic stage is Seneca, the Spanish-born Roman of the middle of the first century A.D. Unfortunately, this one important figure is also the incarnation of the defects of his epoch. He touches no real chord in the public mind or heart; he borrows his subject-matter from the Greeks-Greek gods, Greek heroes, Greek plots; there is nothing national, local, nothing really natural or alive, about his work. The tragedies are mainly excuses for putting fine declamatory speeches or brilliant phrases into the mouths of the characters. They are, in short, exercises in oratory, masquerading in dramatic form. In all probability they were never intended for the stage. Those who know what 
Addison's Cato is like in its coldness and artificiality, those also who know French literature and can remember the declamation in the least interesting of the works of Corneille and Racine, can form a very fair notion of the salient characteristics of the tragedy of Seneca. It was Seneca, the easily accessible Latin model, whom the Italian and French tragedians deliberately copied, and who in turn determined the style of Addison's Cato.

It is perhaps well to remark at this point how thoroughly unreal in every domain of Latin literature is that part which deals with the gods. The native Roman religion had no Olympus, no nymphs. It was a cold and formal worship of gods either far removed or quite artificial abstractions. To a Roman the Greek gods and heroes who fill Latin poetry are more or less ornamental make-believe. They are introduced and regarded rather as poetical properties, virtually meaning little more to the cultivated Romans than the Roman gods, in their turn, mean to an English writer of the eighteenth century, when he talks of Venus or Jove. Therefore, whether it be tragedy or epic or lyric, a dispiriting artificiality generally-although Virgil is an exception-drops upon Latin literature immediately that we find ourselves among the gods and their doings. Yet it cannot be too often repeated that the saving grace of literature is sincerity. No immortal writing can base itself upon convention and a sham.

Perhaps one of the most deplorable legacies left to us by the influence of Latin literature has been the introduction of Jupiter, Juno, Venus, Cupid, Mars, Vulcan, the nymphs, the Graces and the rest into 
the repertoire of what is called poetic diction. As the eighteenth century, more than any other, was dominated by the artificial principles of Roman literature, both directly and through the French, so in that century these names became a set of tinsel tokens to take the place and conceal the lack of honest and genuine ideas and their natural expression.

Leaving Plautus and Terence, we turn to the golden age of Latin literature, its most classical period. Most classical, because during that period its works attain to the "class," the class of the best in their kind. It is between the year 80 b.c. and A.D. I that Latin literature reaches this best, although the kind itself may be in frankness considered not of the most sublime. In point of matter and style Latin literature attains its acme during these last active days of the republic and under the fostering, but at the same time cramping, care of the first emperor, the great Augustus, and his favourite and minister, the munificent Maecerss.

Before this golden period Latin work had been crude, rough, and inharmonious. It is now perfectly polished and used for polished purposes. On the other hand, after this period, in the silver age, there is a loss of purpose, of healthy and genuine subject-matter, and consequently an indulgence in strained cleverness, far-drawn epigram, empty declamation. But during this period itself Latin in the hands of Cicero, Lueretius, Caesar, Catullus, Virgil, Livy, Horace, and Ovid is for the most part sober and restrained. It may not, in most of these cases, 
delve very deep or soar very high, but at least it is both admirable workmanship and marked by sober and practical sense. In the poetry of the epic, the lyric, and the elegiac; in the prose of history, oratory, and philosophy; in all but satire and epigram (which by their nature flourish best in times of decadence), this golden period far transcends the age which followed. It is not in this period that neatly executed nothings, verbal conceits in the absence of true matter, out-of-the-way learning and allusions, take the place of thinking.

It is true that during this Ciceronian and Augustan age the Roman literary art was always conscious in its workmanship, always studied and deliberate, always intentionally aiming at finish or style, at skill and beauty and harmony of expression. It is true that it was seldom prompted by instinct like the Greek. It is true that it was nearly all imitative, unoriginal. But it is also true that it was sensible withal, free from absolute rodomontade, bathos, or frivolity.

The department of poetry from which Latin literature derives most nobility, if no other quality, is the epic. The two greatest epics of the world are indisputably the Iliad of Homer and the Aeneid of Virgil. The Jerusalem Delivered of the Italian poet Tasso and the Paradise Lost of the English Milton rank next, but the distance between either of these works and the Greek and Roman epics is scarcely to be bridged. Probably an epic in the old-world sense is scarcely possible under our modern social conditions and philosophic limitations. 
The epic is the poem of a great action of a great hero. There may be many episodes in the shape of other actions performed by other characters, but, if the art is to be true, all must bear some appreciable relation to, or centre upon, the said great action of the chief great figure. Virgil's Aeneid is an epic left somewhat incomplete; its hero is Aeneas, and the great action is the founding of the Roman race. In the poem are described the wanderings of Aeneas from 'Troy, his adventures by sea and land, his love of Dido and its calamitous ending, his landing in Italy, his descent to the nether world and the sights he there beholds, his wars and victories over the native Italian princes. But the foundation of the Roman race is never reached, the work, which consists already of some ı, ooo lines, having been left unfinished.

The more serious purpose of this ine and noble work was to give to the Romans a great national poem, and to supply them, now that they were masters of the world, with an origin of which to be proud. In this aim the poet completely succeeded, establishing himself at the same time as the supreme national poet of the Empire. We may refrain from blaming him if, meanwhile, he sought to offer poetical incense to the emperor Augustus, by connecting him in direct descent with the Aeneas of heroic exploits and half-divine birth. In such conscious purposes Virgil differs entirely from Homer. Homer composed his verse to be heard or read by all and sundry for its own sake, as a narrative full of life and interest and verbal charm. His works have a nearer claim to be called effusions. But Virgil 
necessarily writes without a simple strong conviction, with more conscious toil of art, as a greatly gifted man of letters writing for men of culture. Spontaneous he assuredly is not. Homer had described battles and councils in the Iliad, and wanderings and marvels in the Odyssey. Virgil borrows the battles or the wanderings, and weaves them with wonderful art into one poem. He takes the similes and imagery of Homer and other Greeks; he translates or paraphrases much of their diction; he "finds his good things wherever he can" and works all into a mosaic, which is exceedingly dexterous, vigorous and polished, but which cannot be called original. The chief sphere of his originality is perhaps to be found in the rhetorical strength and adroitness of many of the speeches which he puts into the mouths of his characters.

Virgil is essentially a writer for the lover of verbal art. For those who can read Latin with easy and scholarly apprehension he appears to combine the splendid harmonies of Milton with the studied grace of Tennyson and often the polished conciseness of Pope. It is impossible to translate him so as to convey any adequate idea of these qualities, for it is exactly these which are untranslatable. Matthew Arnold, in his Essays in Criticism, speaks of individual lines which may serve as touchstones of poetic virtue. In the mere matter of sound each great writer is apt to be distinguishable by such isolated lines. Milton, for example, is only one of many who have written in blank verse. Yet a fragment like

A dungeon horrible on all sides round As one great furnace flamed 
instantly reveals Milton. Virgil answers to the same test of indescribable and incommunicable quality.

To the ignorant Middle Ages Virgil became a name to conjure with. He grew, with little apparent reason except his general poetic fame, to be regarded as the embodiment of all pagan wisdom, and it is for this reason that Dante puts himself under the guidance of Virgil in his Hell and Purgatory, though it is the Christian Beatrice, and not the pagan poet, who accompanies him into Paradise. Dante's Inferno is the sixth book of Virgil's Aeneid expanded and adapted to the strange blend of rapt mysticism and crude realism which prevailed under mediaeval Catholicism. It is from Virgil's sixth book, combined with Dante, that Milton derives the main hint and many of the particular suggestions for his Hell in Paradise Lost. And it is, in short, to Virgil that all epics have looked since his Aeneid once appeared.

Virgil is not, indeed, the only epic poet of Rome, although immeasurably the greatest. Lucan, in the silver age, composed an epic poem of the "great action " of Julius Caesar in crushing Pompey. Like most of the productions of that period of the second best, the Pharsalia is full of epigrammatic sayings, deliberate tours de force and brilliant rhetoric, together with much unreal sentiment, false taste, and grotesque or repellent detail. According to Quintilian Lucan is "more fit to be ranked amongst orators than poets." Soon afterwards comes Statius with his Thebaid, or epic of Thebes, a work of great pains and little life, here and there beautified with those rather morbid colours which have been known to 
suggest the dying dolphin, but incapable of sustaining any natural interest. If he was called "Virgil's ape," the censure is hardly too severe. To us, however, the poem is of some account as having formed a portion of the staple reading in the days of Chaucer, who refers to "Stace" with avowed admiration. The tale of Palamon and Arcite, which Chaucer so admirably transformed from Boccaccio, owes its origin to this somewhat insipid epic of the Roman. Meanwhile the world has been content to forget the partial versions of Statius essayed by Pope or Gray.

In Lyric poetry, apart from the elegiac style, there are two names, and two only, which stand out upon the chart of Roman history. One is Catullus, the other Horace, and both are of the golden age, although of different halves of that epoch. Catullus flourished under the republic about 60 B.c., Horace under Augustus a generation later. It is curious to observe how the verdict of taste is reversing the positions once held in the general estimation by these two exquisite writers. Time was, and not so long ago, when Horace was more read and quoted than any other poet of antiquity. He was quoted at dinners, in literature, in parliament. It was taken for granted that he represented the ne plus ultra of lyric quality. Catullus, it is true, was praised, but comparatively neglected withal. But those who love literature as much for its substance as its form, who seek for inward warmth and for stimulation of the pulses as well as for pleasure of the palate, and who are attracted by the sterling rather than by the elaborated-these set Catullus on a plane to which Horace never reaches. Horace has been called "the poet of 
the man of the world," and the phrase, while fairly true, is manifestly not the highest commendation. Those who read him without prepossession discover that under all his gracefulness he is naturally unimaginative; that, feeling little, he has little power over the heart; and, furthermore, that he is prone to a peculiar inconsequence. Among his virtues is included the characteristic Roman virtue of sound practical sense; but lyric poetry is hardly to be satisfied with that merit. As a man of letters he takes his rank from the perfection of his expression, from his consummate skill of putting the fittest word in the fittest place with a singular terseness and lucidity. To the ancient critic his work was marked by a curiosa felicitas-a " painstaking happiness" of phrase. Meanwhile Catullus possesses a far higher gift, the gift of experiencing a sincere emotion and of communicating it by a rare directness and simplicity of expression, almost after the manner of the Lesbian lyrists or of Robert Burns. This is not to deny that Catullus was a conscious artist, but perfect literature consists in this; that art expends itself on expressing a feeling sincerely felt or a thought sincerely conceived.

Upon Engliṣh literature the Latin lyrists, and more especially Horace, have exercised a far-reaching influence, sometimes with the full consciousness of the English poet, more often indirectly. The "Horatian Ode"-that is to say, the ode in which there is but one comparative short form of stanza repeated throughout-explains its own genesis by its name. In other cases of English lyrics it is not easy, nor is it necessary, to distinguish precisely between 
the debt due to the Latin writers and that due to native-grown song and ballad. English lyrics of feeling would necessarily have developed themselves in some shape without the aid of foreign example, but in point of fact, the Elizabethans, and still more the "cavalier" poets of the seventeenth century, were in the habit of looking to Horace, and in a less degree to Catullus, for suggestions of form and expression and occasionally of thought. For one external indication of this attitude we may look to the practice of the school of Herrick, Suckling, Lovelace, and Waller, who (following Elizabethan sonneteers) habitually call their inspiring mistresses by the names of "Lesbia," "Delia," "Chloe," and the like, for no other reason than that these are the non-committal names sanctioned by the usage of the Latin lyrists.

Elegiac poetry, which, though properly a branch of lyric, has acquired a form and character practically constituting it a class apart, was cultivated and brought to perfection by a group of poets in the last third of the last century before Christ. Tibullus, Propertius, and Ovid are the representatives in Latin of a form of art which had flourished greatly in the lyric age of classical Greece, and had been revived with much distinction, but with a new tone of sentiment, by Callimachus in the age of Alexandria. In Latin Catullus had already taken Callimachus for a model, and transplanted the elegy to Rome. But it was the group above-named who in turns imparted to such compositions a specially Roman character in respect of exacting rules of form. The elegy in early Greece found various themes in martial and social exhortations, moral sentiments, and advice 
or in the expression of personal feelings in different moods. If at Alexandria its matter consisted most frequently of the thoughts and moods of the lover, the modification was due to altered social conditions. It is hard to say what themes might not be treated in the elegiac form, provided they were of moderate length and scope. The Latin poets use the fullest liberty in this respect. Thus Ovid not only writes his Amores or love-poems in the usual sense, his Tristia or personal sorrows in banishment, and his Letters of Heroines, in which the writers pour out their feelings to their absent or unfaithful lovers or husbands, but he also puts together stories of Roman history into a sort of calendar, which is accordingly named the Fasti. A modern poem of reflection, an "occasional" poem, a sonnet, or even Milton's Lycidas, would alike be fitly converted into Latin elegiac verse.

Of the three elegists, Propertius, though remarkably unequal in quality, and often rough and obscure (with an obscurity which suggests Browning), in both expression and allusion, shows the most of native strength and emotional sincerity. Tibullus is the lucid and graceful exponent of the pensive commonplace. Ovid, the master of verbal polish and concision, is to the elegy very much what Horace is to the ode. Facile and prolific, he touches few subjects which he does not adorn. Unfortunately the subjects which he touches are too often shallow and morally unworthy. His attitude is that of a man not only without moral care, but without capacity for any genuine ardour or emotion. He charms with his variety, and with his grace and dexterity of treat- 
ment, but he strikes none of those full or poignant chords which are wont to be stirred by elegies in Greek or English literature.

Other forms of poetical composition among the Romans were the bucolic (or pastoral eclogue), the philosophic, the didactic, the narrative, and the poetry of fable.

Of bucolic or pastoral poetry, as written by the Greeks, something has already been said, as also of the pedigree of this species before its arrival in the literature of England. In Latin literature it is represented almost solely by Virgil, his later imitator Calpurnius being of little account either in himself or his effects. Virgil is the first to introduce the species into Latin, and the line of descent from Theocritus through Virgil to the Italians Sannazaro and Mantuan, and thence to Spenser, is distinct and undisguised. In verse of a certain subtle charm of movement, tinged occasionally with a deliberate rusticity, and pervaded with a suggestion of pensive sympathy rare in Latin writers, Virgil ostensibly tells in dramatic or semi-dramatic form of the loves, labours, sorrows, and songs of shepherds, goatherds, and other simple rural folk. Under this cover, however, he is often in reality touching upon his own personal experiences and those of his friends, or gently couching some poetical moral, or finding a safe vent for the mild philosophizings of his meditative youth. Something of the kind had already been done by the Greek imitators of Theocritus, but Virgil goes much further than they. He has thus changed the whole nature of the pastoral, and, 
artistically considered, for the worse. The shepherds are no longer real and convincing, and the truth of nature's mirror is destroyed. Nevertheless, through a happy trick of cadence, felicitous touches of natural description, and an indescribable atmosphere of sympathy, the Eclogues are wont to exert a charm which defies criticism to do its worst.

Didactic poetry is met with in Virgil's Georgics, or Rules for Husbandmen. In four compositions he deals with corn-crops, fruit-trees, cattle-breeding, and bee-keeping. The model was supplied, as usual, by the Alexandrian Greeks, and for these the ancient inventor and the source was Hesiod. There is no reason to doubt 'Virgil's genuine interest in these practical rustic themes. But, being essentially a poet and not a farmer, he is not to be satisfied with versifying, however skilfully, a list of useful precepts. If the work was, as Merivale considers it, the "glorification of labour," it served meanwhile as a frame for special passages of great beauty upon topics more or less naturally associated with the matter in hand. The poet on occasion finds it no long step to take from the weather to eclipses, from eclipses to the death of Caesar, and from Caesar to patriotic reflections. The digressions are not so far afield, nor so numerous as in Cowper's Task, but that work may perhaps be cited in partial illustration.

Didactic in another kind is that short Art of Poetry, written in deft verse by Horace, which was copied by Boileau in his Art Poétique, and freely utilized by Pope in his Essay on Criticism. Its professed aim is to inculcate certain principles of poetic com- 
position, and, in particular, the composition of drama. Inasmuch as Horace was drawing upon Greek doctrines derived from Aristotle, but not always understood by their somewhat superficial Roman poetizer; inasmuch also as poetic drama had no real existence in the days of Horace, there was little prospect that the Art of Poetry would shed any new illumination upon the world. To those who have read the seminal work of Aristotle, the precepts of Horace inevitably appear rather trite and shallow. The writer here, as elsewhere, is marked by shrewd and humorous good sense and a gift of terse expression, and it must be admitted that these form an excellent endowment for the middleman of intellectual traffic. The essay would doubtless be read by his contemporaries with enjoyment, and in many cases with edification. The misfortune is that, from the later seventeenth century onwards, it was the superficial Horace rather than the fundamental Aristotle who served as dictator of the laws of verse to both England and France.

Philosophic verse, which is, of course, a species of the didactic, finds its best representative, not merely for Latin literature, but for the literature of the world, in Lucretius, who wrote during the latter days of republican Rome. His poem On the Nature of Things is an exposition of the philosophy of Epicurus, as developed from the physical speculations of Democritus. According to this philosophy the original contents of the universe were minute atoms, the "seeds" or "elements" of things, moving in a void. By their fortuitous collisions and various combinations were formed all things as they 
are or have been. To this extent had ancient speculation, combining bold imagination with close reasoning, anticipated modern chemistry and astronomical hypothesis. From crude and accidental beginnings, says Lucretius, there ensues a "survival of the fittest," and thus, though unaided by modern scientific appliances, and imperfectly directed from the point of view of modern scientific method, ancient speculation anticipates also the doctrines of modern evolutionists. In the application of these results to the conduct of life (which is the practical aim of philosophy) it is evident that current theology must receive a severe blow. To Lucretius the chief blessing derived from the true philosophy is that man is emancipated from superstition, with all its terrors in life and death and all the mischiefs it has worked. We may conjecture that the soul of the poet himself, which was brooding and melancholy, would have been eminently impressible by superstitious dread, if it had not been fortified by this wisdom of "the master." His fervent onslaught on religio (in the Latin sense) and its crushing effects can hardly be otherwise explained. He does not-nor did Epicurus-absolutely deny the existance of gods; these are logically as producible as other "things." What he denies is their interference with the processes of nature. All this and more he sets forth in the six books of the De Rerum Natura.

In the use of verse as the vehicle of philosophic teaching, Lucretius is but following the lead of the older Greeks, Empedocles, Xenophanes, or Parmenides. The task is technically difficult, and in modern times it would be purposeless. But for 
Lucretius we must not only grant the utility of the method in awakening intellectual interest as widely as possible among a community less prepared for philosophy than for poetry; we are also compelled to recognize that his effort to make philosophy talk in Latin verse was technically a triumph. Yet Lucretius is much more than a translator of Greek philosophy into Latin hexameters. $\mathrm{He}$ is a poet. Doubtless the passages in which he is setting forth bare statement of theory, or bare argument, are of necessity as dull as many passages of theologizing in Milton's Paradise Lost or Paradise Regained, or as many passages in Wordsworth's Excursion. But when the poetic opportunity arrives, and when he is irresistibly borne away with such reflections as those upon the life and death of man, he writes in lines as splendid as those of Milton and Wordsworth at their best. Through all the work there is a tone of the ardent missionary of intellectual deliverance, blent with a certain melancholy which recalls Ecclesiastes. Latin literature is not strong in great intellectual forces, but among these Lucretius must hold a foremost place.

Narrative poetry, apart from epic, occupies no large space in the literature of Latin. The Metamorphoses of Ovid practically stand alone. These, written in a lighter and more fluent hexameter than that of Virgil's Aeneid, are a series of stories dealing, as the title shows, with the various transformations undergone by human beings in mythology or legend. If there is anything in Latin answering to the "romantic" elements in Ariosto or Spenser it is to be found here. The author, knowing the stories 
to be fabulous, employs all his fancy and inventiveness, his descriptive power and gift of language, in embellishing them. Men and women are turned into beasts, birds, monsters, trees, or stones with much poetic gusto of circumstance. The want of real unity is no drawback to the work; the telling of the legends is brilliant; the stories themselves are such as at all times appeal to the lovers of the romantic and the marvellous, and particularly to the young. From these causes it is not too much to say that the influence of the Metamorphoses has been immeasurable. The usual mediaeval, renaissance, and modern répertoires of mythological story have been almost entirely derived from Ovid. To the better read contemporaries of Chaucer, as of Shakespeare, Ovid supplied not only the matter, but the spirit of such narrative. Such a familiar legend as that touching one of Philemon and Baucis may be Greek in origin, but it is Ovid who has made it the property of the later western world.

Not inappropriately may be introduced here the mention of a minor writer, whose work, despite its slender substance and its narrow range of genius, has been far-reaching in its legacy. This is Phaedrus, the versifier of fables in the reign of Tiberius. With no special brilliancy or gift of invention, but with a style of lucid simplicity which is excellent for such narration, Phaedrus puts into verse the Greek fables-commonly fathered all alike on "Aesop "which he could find current in his day. The collection is probably much the same as that of the Greek Demetrius Phalereus (300 B.c.). From the point of view of both morals and language the book served admir- 
ably for schoolboys, and it is at least one of the main sources of the fables which found their way into England, first with Alfred, and later, in more force, with Caxton's "Aesop."

In one branch of verse-writing, which must next be considered, the Roman writers have every claim to the credit of originality. There has always been, as there is at the present day, in the Italian mind a pronounced strain of satire and irony, a tendency to lampoon and epigram, a disposition to look on the seamy or ridiculous side of things. The Aretino of later Italy is a true descendant of the Lucilius of ancient Rome. The Romans themselves claimed as their very own the form of composition known as satura. Satire, as a tone, may appear in Greek writers of various kinds; it may even approach a special recognition in certain portions of the Old Comedy of Athens; but there existed no Greek example of a separate composition with the character implied in "a satire." The word itself, however, demands some examination. To us it primarily implies fault-finding, general or particular, and such the satire became, particularly in the hands of Juvenal. But originally satura meant a mixed dish, a medley of observations upon society and men. These observations naturally took the form of describing habits and revealing motives. It would follow that, according to the temperament of the writer, the satura might become either a moral essay or a satire in the modern sense. Bitterness is not properly essential to such compositions, and in the Satires of Horace there is comparatively little of that quality. His Epistles, which are practically 
only saturae under another name, are still more distinguished by geniality. Nevertheless, just as "censure" began by meaning "judgement" and has come to mean unfavourable judgement, so "satire" speedily limited its implication even among the Romans. A hundred years before Horace a certain Lucilius (of whom only fragments remain) had practised a vigorous but rough invective in his saturae, but for us it is Horace who represents the establishment of satire as a species of cultivated writing. To him these compositions were sermones, or "talks," and they were permitted to serve as the vehicle for a frank egotism not unlike that of the Essais of Montaigne. They are "satirical" in that they from time to time administer more or less caustic chastisement to contemporary follies or vices. Three-quarters of a century later, in the silver age, Persius put forth a small book of satires full of promise, but also full of faults in the way of obscurities and artificialities of style. Trained as a philosopher, he had studied mankind from books, and particularly from Horace, rather than from experience, and, as he died at twenty-eight, it may be presupposed that his insight is far from deep. Fortunately he was withheld from the savage invective customary with youth by his philosophic sincerity and the mildness of his nature. It is early in the next century that satire, in the hands of Juvenal, becomes the polished and trenchant weapon of offence now commonly understood by the term. Juvenal became, and has remained, the very prince of those who condense wit and sarcasm into pungent and rememberable lines of the most consummate terseness. 
He possesses a singular power of presenting moral vices and social foibles and follies in all their contemptibleness, and there is ample reason to believe that, as he expressed it, it was indignation which created his lines. It is Juvenal and Horace, though chiefly the former, who have served as models for Dryden and Pope, for Hall and Butler, and for Byron in his English Bards and Scotch Reviewers. The less fierce and more descriptive part of Juvenal's work also found a notable imitation in Johnson, whose London is copied from one satire and his Vanity of Human Wishes from another.

Often cognate to satire is epigram, as treated by Martial, a writer of the generation preceding Juvenal. An epigram is, in fact, apt to be a stinging satire in little. This is, however, a very distinct departure from the nature and province of epigram as employed by the Greeks. Of this something has already been said. It would, nevertheless, be a mistake to suppose that the narrow sense now usually, if erroneously, given to "epigram" was equally the sense in which it would have been understood by the contemporaries of Martial. The "sting in the tail" is by no means indispensable. That the wit and verbal dexterity of Martial were so often applied to caustic purposes was no hindrance to the use of the same qualities in epigrams of compliment, of fancy, of description, and of mere humour. We cannot, it is true, assign to Martial a place in "poetry" proper. A man without convictions or much refinement of feeling, but well acquainted with his world, witty, and a manipulator of phrase, he poured out more than a thousand of these little pieces, many 
excellent, many execrable, many indifferent. But in this species of literature-be it worth what it mayit is Martial who has determined the form and matter of the epigram for modern Europe.

In prose, Roman literature is very copious, although not equally rich in all domains. Its chief strength lies in history, after which come philosophical works, oratory, and letter-writing. With Roman jurisprudence and with grammatical (or philological) writing we are not here concerned. The famous Cato, the Censor (I84 B.C.), has left us a treatise On Agriculture, consisting of practical maxims which are scarcely literature; and a large number of didactic works (many of which are not preserved, or only preserved in fragments) were produced at different dates of the republic or the empire by men of distinction. Thus Varro, a most erudite contemporary of Cicero, wrote voluminously upon Antiquities Human and Divine, upon The Latin Language, and upon Agriculture. Seneca the elder, in the reign of Tiberius, collected educational examples of methods of rhetorical disputation. In the time of Claudius medicine was treated by Celsus. Columella exhausted the subject of agriculture. During the Flavian régime Frontinus composed a treatise on aqueducts and another upon military operations, and the laborious Pliny the elder put together thirty-seven books on Natural History, a vast cyclopaedia of mixed truth and untruth concerning all departments of natural science, the arts connected therewith, and the fine arts to boot. But, whatever merits and demerits of style these works 
display, they hardly merit discussion in so general an outline of literary history as this. It is impossible to say what information or ideas in our modern possession might be traceable to writers like these, but they can scarcely rank as appreciable "literary influences." Doubtless Pliny's encyclopaedia is ultimately responsible for much of the confused natural history of the middle ages, and not only Chaucer, but also the sixteenth-century Euphuists, with their egregious similitudes, are almost certainly in his debt. The affiliation of scientific knowledge and error, however, lies beyond our scope.

In the field of history, Latin literature presents us with various attitudes and styles. Historical writing in general may be of at least three salient kinds. The first kind is imaginative, credulous, careless of accuracy so long as the story is attractive, the narrative being, as Quintilian would have it, "akin to poetry." In the second kind, sheer imagination may play no pronounced part, but there may be a rhetorical tendency to embellish and expand, and to exaggerate the lights and shades. The third kind is direct, simple, impartial, shrewdly critical. In classical Roman history we have (besides the "Lives" of Nepos), the works of Sallust, Caesar, Livy, Tacitus, and Suetonius. We cannot take all these together and refer them to any one of the abovenamed descriptions. So far as there is a characteristic common to any group of them it is to be found in the fact that Sallust, Livy, and Tacitus all show in various ways the customary Roman taste for rhetorical effect. To this extent they are not greater sinners than Macaulay or Carlyle, who, like them, 
fall into the second of the divisions described. Meanwhile the Commentaries (or "Notebooks") of Caesar offer the best example that Latin can supply of the third style. His plain narrative in straightforward Latin is easily distinguished from the rich and picturesque eloquence of Livy, the conscious stylism and laboured point of Sallust, and the epigrammatic brilliance of Tacitus. Once more Suetonius, a naturally inferior writer in a decadent age, is the precursor, in his Lives of the Twelve Caesars, of that less ambitious history which gossips and "deals in ana" concerning great personages and their surroundings. Among all the Roman writers it is in vain that we seek the historian who will, like Thucydides, describe the facts with a lucid and serene impartiality, while clothing them with that style of supreme art which makes them live before the reader.

These qualifications made, it still remains indisputable that Livy and Tacitus are two of the very foremost historians in the literature of the world. The unpretentious work of Caesar has its claim as well as its intrinsic interest, but it cannot rank with these. Sallust, despite undeniable merits, is placed in a minor rank by the triteness of his ideas and the obviousness of his reflections. But Livy, in virtue of his superb eloquence and unflagging descriptive power, and Tacitus, in virtue of his shrewd insight and vivid presentation in a style inimitable for its sparkling condensation-these will remain for ever admirable, as they were, one or other, admired and followed by Gibbon, Macaulay, or Carlyle. Of the vast work of Livy, written in the reign of Augustus, 
and entitled The History of Rome from its Foundation, we possess but a portion, although that portion is in itself of considerable dimensions. As Latin prose, the style is magnificent in variety and colour. It may be called Gibbon, without Gibbon's sameness or too frequent ponderousness; Gibbon warmed by patriotic ardour. That it sometimes suggests the poetical is assuredly no drawback to what, after all, is a narrative intended primarily to be read. As sober history it suffers from the shortcoming that Livy hardly concerns himself with the verification and criticism of authorities. He does not wholly emancipate himself from the first type of historian. If Tacitus, a hundred years later, cannot be called credulous, neither can he be called impartial. While we have no right to doubt his moral earnestness, we have reasons for doubting his authority - or his use of his authority-for the motives and conduct of the emperors who reigned before his own time. As with Carlyle, and as with Macaulay, his temperament and views led him to darken all the shades and whiten the brightnesses. But, when we have admitted this, it is impossible to rise from his Annals or Histories of imperial Rome without feeling that men and women and events have been brought before the mind's eye with a wonderful vividness, nor without remembering many a phrase amazingly packed with meaning. Whatever philosophic criticism may have to say of Livy and Tacitus as history, they possess the essential literary merit, that they captivate.

If in the region of philosophy we include, with works of morals and politics, works on the principles 
and practice of rhetoric-a department to which the Romans attached an unusual, but not unaccountable, importance-we have to deal with three great names. These are Cicero, Seneca, and Quintilian. The lastmentioned concerns himself with oratory, the second with moral philosophy, while to Cicero nothing comes amiss. Here, as generally elsewhere, the Latin genius makes little claim to originality. When Cicero writes On the Orator he is doubtless fully at home with his subject; nevertheless he is practically converting into Latin, with embellishments and enlargements, the system and terminology of the Greeks. His moral treatises, which are excellent reading in their kind, are but the expositions of an extremely clever man, who rightly thought that he was rendering no small service to his own countrymen by giving them in compact and intelligible form the substance of Greek philosophy. With a view to imparting lightness to his themes, and led by the example of Plato, he adopts the device of a pretended conversation or disputation, but it can scarcely be said that he lends much verisimilitude to the situation. The style everywhere is lofty, the thinking is serious and helpful, if not profound or original, and it is difficult to over-estimate the influence exercised by these books upon the later thought of Rome, of the Middle Ages, or of the Renaissance. Seneca the younger, writing under Claudius and Nero, is a philosopher in the more strict sense of the term. Living in an age which demanded striking phrase, point, and epigram, he is a master in that style. None the less he was a deep and earnest thinker. Cicero, in dealing with stoicism, is the highly in- 
telligent amateur; Seneca is the expert, but not a pedantic one. His Moral Epistles and his dialogues are essays touching upon matters of daily ethical concern, and both in their matter and its presentation they deserve a much wider recognition than they commonly receive. Some such recognition they did obtain at the Revival of Learning, when Englishmen read the classics more for what they contained than for the niceties of philology. It follows that the thoughts of Seneca, acknowledged or not, have played no small part in modern literature.

Quintilian, a salaried professor and practitioner of rhetoric under the Flavian emperors, has left us an exhaustive treatise upon The Training of the Orator, a training which begins at the cradle. The work sets forth in all their completeness the principles of oratory, but it is incidentally a discussion of education in a wider sense. The formation of "a good man skilled in speaking" involves more than the cultivation of language and the mastery of speech and delivery. It implies great mental culture, and particularly culture derived from literature. To subsequent ages Quintilian became an authoritative lawgiver in the domain of rhetoric, criticism, and language. Doubtless it would have been intellectually better for the later European world to study its philosophy and culture in the Greek originals, but, these being commonly inaccessible, all gratitude is due to Cicero, Seneca, and Quintilian for supplying so excellent a substitute in Latin.

Roman oratory, in the form of written speeches, is fortunately represented for us by the greatest of Roman orators. It is a trite observation that oratory 
can have no existence, except artificially, under a despotism. Cicero, however, lived in the last days of the republic, when speech was still free, burning questions numerous, and the art of public speaking fully developed. Accordingly in his long list of public speeches he has complete liberty to express himself with such vigour, passion, pathos or humour as he chooses. The Roman ideal still demanded from a great public character the quality of gravitas, a moral impressiveness; that quality was in any case congenial to Cicero; but, with that maintained, his scope was un restricted. To the modern reader the oratorical greatness of Cicero lies in the verbal eloquence rather than in strenuous cogency of thought, or in those powerful flashes which come from Demosthenes. He is an ingenious special pleader, a tactful disposer of arguments; but, above all, he is a master of full, rich, sonorous, impressive, and overwhelming language. As compared with Demosthenes, he is at times somewhat too copious, and even too florid; he is evidently speaking to a people less critical and less true in taste; his humour is apt to be awkward; nevertheless the impression left upon the reader is that of a man who employed superlative gifts, natural and acquired, in an art of which he entertained a lofty conception. It is not too much to say that the highest eloquence of Italy, France, and England has at all times striven to be Ciceronian. Cicero was the model, consciously or unconsciously, of Burke, Pitt, Fox, or Gladstone, just as he was the model of great French preachers like Bossuet. It is perhaps one mark of his inferiority to Demosthenes that he can be thus imitated. 
Demosthenes himself is inimitable. In its later stages Roman oratory was too much given to hunting the phrase, its decoration became vicious with efforts of preciosity. But it cannot be said that these productions of decadence have exercised any appreciable effect upon English speaking or writing.

Just as in verse the Romans invented one form of literature, the satire, so in prose they probably invented the epistle or letter. In Greek literature letters are seldom found; those which are found are of dubious authenticity, and in any case they are but essays in epistolary form. But in Latin we meet with two great letter-writers, who, if they had written nothing else, would have occupied the same positions in literature as are occupied by Horace Walpole in England and by Madame de Sévigné in France. The correspondence of Cicero was followed, a century and a half later, by the correspondence of Pliny the younger, and both are full of literary and also of historical interest. How far any of the letters of Cicero were intended for publication is doubtful; very many of them obviously were not. Those of Pliny, however, were carefully composed with the distinct object of being given to the world. Apart from the different characters and environment of the two men, there is consequently an appreciable dissimilarity in the style. Except when he is writing formal or courtesy letters to comparative strangers the correspondence of Cicero carries with it a natural and unstudied air. He is vehement, jocular, despondent, testy, as he thinks fit. He puns frecly, breaks off a sentence, quotes Greek, or uses colloquial terms. It would have been well if critics of 
Cicero's character had remembered to distinguish private and not always serious correspondence from public behaviour. With Pliny the case is otherwise. He was constitutionally a kindly man, with a genuine love for letters; by training he was a staid man of affairs; in circumstances he was rich, and his later years were leisured. But he was withal a man who took himself with some excess of seriousness. In any case he would not have forgotten what was orthodox for a Roman gentleman; least of all was he likely to forget it in letters destined for publication. His epistles are therefore always marked by a certain reserve and a suggestion that they are intended to rank as literature. Probably there would have been less unbending still, except for the warrant of the letters of Cicero, who is plainly his model. Yet, in spite of these drawbacks, they give an excellent picture of contemporary Roman life, and afford an insight, otherwise unattainable, into current Roman sentiment. For us it is important to note that the literary letter-writing of France and England was, in the first instance, directly suggested by these patterns of ancient Rome.

\section{* * * * * * * * * * *}

Despite the fact that there were three well marked periods in the history of classical Latin literature, there are, nevertheless, certain characteristics which appertain to that literature considered as a whole. To say this is not to maintain that all Latin writers are monotonously alike. Enough has been said already to demonstrate the contrary. It is only meant that, taking writer after writer, and department of literature after department, we can discover 
certain traits common to the majority of them, and that these traits give a national character to the total body of production. In the case of the Greeks the characteristic was the clear-cut presentation of genuine thought or feeling at first-hand. In the case of the Latins the case can hardly be stated so simply. Yet the following observations may assist towards a fair generalization.

In the first place Latin literature is for the most part confessedly imitative. It sets itself foreign models. Its standard of excellence does not so much lie in the consciousness of having given a completely truthful expression to a thought or emotion, as in the supposed success with which a writer reproduces or transplants some Greek exemplar, modifying it to what is believed to be unavoidably required by conditions of the Roman tongue and Roman culture. It is in this spirit that the comedians, the tragedians, the epic, lyric, and elegiac poets-Plautus, Terence, Seneca, Virgil, Horace, Ovid-set about their work. It is in this spirit that historians like Sallust, literary critics like Horace, philosophic writers like Cicero, set about theirs. They are all avowedly adapting Greek thoughts, Greek plots, Greek rhythms, and Greek expressions, so far as the Latin can be made to admit them with elegance. And in this sccondary kind of work they were eminently successful. They contrived somelow to make the Latin tongue do the work which they asked of it. Horace and Virgil are consummate masters in this tasteful but unoriginal labour. Thanks to them the forms and metres of Sappho and Alcaeus, of Homer and Theocritus, were reproduced with only just so mucli difference 
as the nature of the Latin tongue rendered unavoidable. The result was verse of perfect polish and ease, and of splendid harmony. But creators in any large sense they were not. They were magnificent technical artists, of the kind who can reproduce an original picture as a perfect etching with modifications, or who can carve and elaborate artistic decorations if they are supplied with a portfolio of designs. Possibly in this proceeding they worked some injustice to Latin capabilities. It is conceivable that a number of Latin writers might have left us work of much more essential strength if they had allowed their own creative genius freer play. It was well that they should learn from the Greeks, but not so well that they should mimic them. It is somewhat as if the Germans, instead of writing from the full nature of a Goethe, a Schiller, or their balladists, had followed the example of Frederick the Great and put themselves into as complete a pupilage to the models from France. There are instances in which the Latin genius did actually follow its own course after gathering technical lessons from the Greeks, and the result is then of such excellence that we cannot help feeling some regret at the prevalence of deliberate imitation. The most truly spontaneous, and therefore most creative, writers in Latin are Lucretius the philosophic poet, Catullus the lyrist, Juvenal the satirist, the letter-writers Cicero and Pliny, and the historians Caesar, Livy, and Tacitus. Of these Lucretius, Catullus, and Caesar are frank and genuine men with corresponding thoughts. They learn what Greece can teach in the way of form, and then set themselves to deliver their 
own souls. In letter-writing and in satire the native genius, strong in those directions, broke out without assistance.

The first prevailing characteristic of Latin literature, then, is its deliberate secondariness, which too often goes with lack of serious purpose.

The second consists in a remarkable zest for polish of expression, a studied elaboration of elegant diction and pointed phrase, which may recall in some cases Pope, in others Tennyson. Something of this is due to a necessarily disproportionate care for words in the absence of substantial or novel matter; something is also due to the constitutional Italian genius, which excels in cameo-cutting, whether in the literal or the metaphorical sense. Doubtless the ideal literature combines the exquisite expression with the original thought, but, if we must make some surrender, we should naturally prefer to leave the brilliancy in the thought. Latin writers, however, on the whole rather agreed with Boileau and Pope, that the aim of literature was to utter "what oft was thought, but ne'er so well expressed." The result with them is that the most famous of their poets are unsurpassable verbal artists, and that their silver age writers are in particular exceedingly deft in the command of terse and pointed phrase. But the result is also that their inferior writers were apt to become mere tricksters and contortionists in words. Nevertheless, it is one indefeasible ground of praise of the literature of Rome that it did thus set itself and us a high ideal in the way of melodious or compact and rememberable diction.

There is a third consideration. Greek literature 
reached its perfection in the midst of free and stirring democratic activities; it was therefore addressed to the mind and heart of the people at large. At Rome, on the contrary, literature only reached its technical acme when freedom was practically extinct. The work of Virgil, Horace, and Ovid, belongs already to a period of despotism. It is addressed first to imperial ears and then to those of an aristocracy more or less idle. It is in a large measure written by a coterie for a coterie, or by a dependant for patrons, its object being to entertain elegantly. For that reason it avoids emotional depths and altitudes, and shuns intellectual audacities. It seeks to say clever things, displaying culture and knowledge agreeable to a society which plays with such matters. It adheres to a certain ideal of " good form," which, however, does not preclude plenty of such allusion as will show wide reading and social experience. Ardours for the vital interests of society, and the frankness of large natures communicating with their fellow men, are necessarily taboo. Whether these existed largely in Roman natures is, as has been said already, matter for doubt, but almost certainly they existed beyond the extent to which expression was countenanced. It is therefore with more justice than is commonly perceived that the "Augustan" age of English literature has received that name.

It seems not unjust to sum up Roman literature -allowing for the exceptions already made-as a literature largely imitative and secondary, highly polished and elegant in execution, but limited in its intellectual and emotional range as in its originality. 
The influence, direct and indirect, of Latin literature upon English is perhaps best realized from the tabulations which appear in this volume. Nevertheless it may be helpful to make sundry notes upon certain more obvious debts taken in chronological order.

In and before the age of Chaucer the poems of Ovid upon love and its cure were much drawn upon by writers of romances and allegories. They were the direct inspiration of much of the troubadour poetry of Provence and thence of the mediaeval lyric verse of Europe in general. Ovidian borrowings are manifest in the Romance of the Rose. Chaucer himself was a student of Ovid, Lucan, Virgil, "Stace," and also Livy. From Ovid's Metamorphoses and love-elegies in particular he took much matter. His Knight's Tale is ultimately from the Thebaid of Statius. The reading of his contemporary Gower, and of his successor Lydgate, was even more deep in the same authors. At the beginning of the sixteenth century Gawin Douglas translated the Aeneid, and soon afterwards Wyatt and Surrey show themselves steeped in Seneca and the epigrams of Martial; Surrey also translated portions of the Aeneid. Before Marlowe and Shakespeare the more scholarly pioneers of drama, such as Sackville, sought for tragic models in Seneca and for comic models in Plautus. Elizabethan readers ransacked all available Latin books. Spenser's Eclogutes follow Virgil's, and his Faerie Queene is full of borrowings from the Aeneid and from Ovid's Metamorphoses. The effect of Ovid on Shakespeare himself is manifest in his Venus and Adonis. Bacon who, like all 
the great prose-writers of his time, could use both English and Latin, shows in especial the influence of Seneca. Ben Jonson, who translated portions of Horace and Martial, is an imitator of Horace in the way of poetical epistles and short lyrics, and of Martial in epigram. In the school of the "Sons of Ben " and the "Cavalier poets," we meet with very distinct manifestations of the combined influence of the lyrists Horace and Catullus and the epigrammatist Martial. We know these to have been favourite poetic reading of the period. Simultaneously the general style of prose-writing, whether as in Milton or as in Jeremy Taylor, was imagined to be based upon the rounded periodic style of Cicero, and the language itself is deliberately Latinized to a remarkable degree. Milton, who wrote Latin poems as well as English, is greatly and openly indebted in his epics to both the matter and the manner of Virgil. The post-Restoration comedy derives itself through a French medium from that of Plautus and Terence. At the same time the second-hand critical principles of Rome begin to prevail in England. Roscommon translates the Ars Poetica of Horace; Dryden translates the Aeneid and passages of Ovid; he also writes powerful satire in direct imitation of Juvenal. Addison produced his Campaign under the influence of Lucan, and his Cato under the influence of Seneca. Pope begins with pastorals after the manner of Virgil and Theocritus, composes Imitations of Horace, and copies the Ars Poetica and Epistles and Satires in his own poetical essays on criticism and morals. His Messiah is a recasting of Virgil's fourth Eclogue and his Eloisa to Abelard is based on Ovid's Heroides. 
Samuel Johnson's London and Vanity of Human Wishes are similar copies of Juvenal, while his prose seeks to model itself upon the Ciceronian. The great preachers and orators of the eighteenth century are Latinists in their rhetorical principles. During the same age the didactic poems, such as Dyer's Fleece or Akenside's Pleasures of the Imagination, are the outcome of the study of Lucretius and the Georgics of Virgil. The letters of Pope or Walpole no less distinctly take their hint from Cicero and Pliny.

It is unnecessary to elaborate further a bare catalogue of such obligations. It is, perhaps, more useful to emphasize one consideration which should bring home the vast, if undefinable, influence necessarily exercised by Latin thoughts and Latin expression upon English writers. Before the days of Alfred and the days of Chaucer the chief writers of prose in England composed in some sort of Latin. They knew Latin, and read such Latin books as they could get. From the Revival of Learning Latin came more and more to be studied as modern languages are studied now, for the sake of actual speech, correspondence, or controversy. The pens of Englishmen like Sir Thomas More, Bacon, and Milton, were fluent in Latin. Ben Jonson, Cowley, Addison, and Samuel Johnson were great Latinists among a society in which Latin knowledge was general. Landor and De Quincey were no less great. There are few writers in the English language who have not received at least some tinge of Latin education. Familiar as all these generations have been with Latin books, practised in the imitation of Latin dic- 
tion, filling the language with Latin terms, it is quite impossible to determine how deeply we are steeped in the influence which has passed through them. During the last century it is true that education has not cultivated that fluency in spoken Latin which marked the two or three centuries preceding. Latin is no longer necessary as a medium for the interchange of thought, and the increasing number of arts and sciences restricts the prominence of any one study. On the other hand it is no less true that almost every considerable writer and speaker of the century had received that more recent form of Latin education which consists in an accurate and tasteful study of the words, styles and thoughts of the best, or most classic, of the Roman writers-Catullus, Lucretius, Cicero, Virgil, Horace, Livy, Ovidrather than Lucan or Statius. The influence of Roman literature during that period has been more wholesome than during the later period of the seventeenth and the greater part of the eighteenth century, an epoch in which English writers delivered themselves over to almost as servile a subjection to Latin (or rather Latin-French) patterns as the Romans had once, with more reason, assumed towards the Greeks. That era, the era of Dryden, Pope, Addison, Johnson, is in this sense the most Roman period of our literary history. To it, unfortunately, we owe all that personification of abstract qualities by the simple device of a capital letter; all that use of "nymph" for "woman" and "fire" for "love"; all that stereotyped phraseology, such as "reddening Phoebus lifts his golden fire" for the "sun is rising," from 



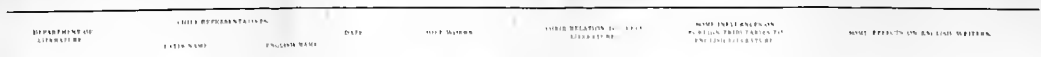

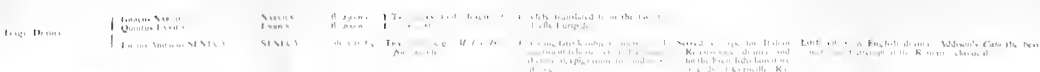

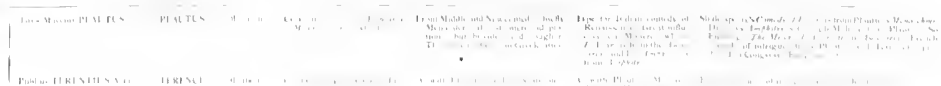
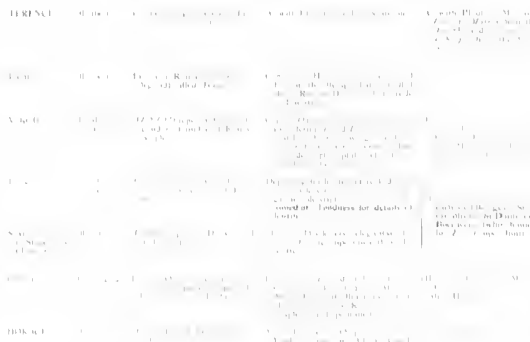

$\because+1.4$
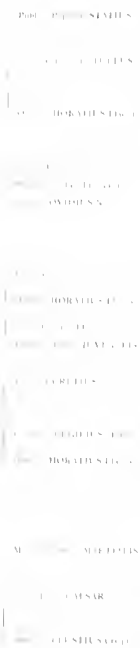

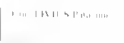

$\because 1$

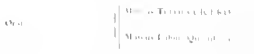

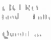

(ii) kit

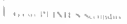

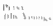

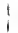




\section{INFLUENCE ON ENGLISH 115}

which we were delivered by Burns and Wordsworth. To the Romans themselves these terms were artificial enough, to the English they were doubly artificial. 


\section{III}

\section{LITERARY CURRENTS OF THE DARK AGES}

I ATIN literature, despite its decline after the classical period, is marked by a number of names which merit eminence in their several domains. The era succeeding the silver age hardly deserves to be called leaden. Literature does, indeed, both descend from the Virgilian and Ciceronian style of language, and also adopt a less classic attitude in its themes and sentiment, but it is not without a life and value of its own. Some of the writers are pagan, some are Christian, but their religious professions are not to be determined by their dates. Apuleius, the African writer, a professional rhetorician and man of letters, who wrote his prose Metamorphoses or Golden Ass in the second century, is, of course, a pagan, and by no means a model one. The work just mentioned, probably based on current folk-tales, is entirely fiction, narrating the story of a man turned by sorcery into an ass, and describing his adventures, scandalous, distressful, or amusing, in the hands of robbers and other low types of a society which, we may trust, was not really so bad as it is here painted. Yet into this otherwise not very edifying work there comes 
the exquisite story of Cupid and Psyche, which has been so frequently translated or recast in literature -best of all by William Morris in the Earthly Paradise-and so frequently utilized as the subject of pictorial or plastic art.

From the beginning of the third century until the fifth, Christian views find their exponents in Tertullian, Lactantius, Ambrose, Prudentius, Jerome, and Augustine. To Jerome is due in particular that Latin version of the Bible of which the present Vulgate represents successive partial revisions, to Augustine the City of God, to Ambrose the initiation of the Christian hymn, and to Prudentius its development. Christian also is the Gallo-Roman poet Ausonius, of the later fourth century, but his verse is by no means dedicated to Christian teaching. In him appears what might seem to be a modern, if not fully "romantic," partiality for affectionate observation of natural scenery, best illustrated by his well-known description of the stream and banks of the Moselle.

Meanwhile among pagan writers must be reckoned Ammianus, a picturesque and interesting historian, who undertook to bring the work of Tacitus up to the year 378; Macrobius, whose Saturnalia discourses in a desultory fashion on a variety of literary and social topics; and Claudian, the composer of polished poems on contemporary history, in which extremely skilful polish of verse is united to brilliant gifts of description. The religion of Boethius, the last man of letters who can be said to linger on the border of the classical world, but who in style and thought stands nearer to it than many an earlier 
writer, is doubtful. In all probability he was a pagan, but he concerned himself, not with religion, but with philosophy as reflected from Plato. His De Consolatione, or Consolations of Philosophy, is a prose work interspersed with verses, and in virtue of this production, which often rises to great excellence, Boethius stood to the Dark Ages for the exemplar of the philosopher. His place in mediaeval reading was a very high one, and may be gauged from the fact that in England Alfred the Great translated his Consolations into Anglo-Saxon, though with insertions and comments of his own. To Chaucer, as to all the mediaeval world, "Boece" was part of the staple library.

During the centuries from the decay of the literature of Rome till the emergence of the modern literatures of western Europe there occur the great migrations of conquering peoples and the forming of the new nations. The Gothic conquests of Italy and Spain, the movements of the Franks, Burgundians, and Lombards, the story of Alaric or Theodoric, of Pharamond or Clovis, belong to history, as do the settlement of the Anglo-Saxon and Danish tribes in Britain and the occupation of Normandy by the men from whom it is named. Against these Teutonic triumphs and their influence to the north must be set the Moslem triumphs and influence to the south. Not only did the Moors conquer and hold for centuries the greater part of the Spanish peninsula, but Sicily also passed for five generations into the hands of the Saracens. In England a national history commences with Alfred at the close 
of the ninth century, but its development, both from a literary and social point of view, was decply modified at the Norman Conquest. In France and Germany the empire of Charlemagne, the great fact of the eighth century, had done much towards consolidating culture and reviving learning. At the end of the eleventh century began the Crusades, which helped to bring the western nations into closer touch with each other and also into contact with the Greek world and with legends of the east. Meanwhile, the Christians of north-west Spain were gradually winning back their country from the Moors, but, in the process, absorbing no little of their Arabic culture.

By the twelfth century the modern Romance tongues, Italian, French, Provençal, and Castilian, are sufficiently formed for literary purposes, and the speakers of those languages have attained to the position of steady and settled communities. Though the English language is temporarily in abeyance for literary uses, the English nation is free from further disturbance, while nevertheless it is now happily placed in direct communication with continental tendencies and ideas. In the meantime it must not be forgotten that Europe had now become Christian, and that in the west the teaching of one great Church was common to all the nations.

This long period of disintegration and re-construction is for the most part so little studied, and is, in fact, comparatively so studiously ignored, that we are apt to forget how long it actually was. The literary productions of nearly seven hundred years are regarded as of so little moment that we forget 
there were any at all. Yet for a proper comprehension of the inter-relations of literature as affecting the development of our own, it is necessary to form some conception of the various literary currents of these "Dark Ages."

As might perhaps be anticipated after a survey of the historical movements and situations, we have to reckon with:

(1) Such Latin literature, of classical or later date, as survived after the wreck of the empire and still formed part of, at least, the higher reading.

(2) Such new productions in Latin as appeared before the new tongues were formed.

(3) The matter and influence of the literature of the Church, comprising the Hebrew Scriptures, chiefly in the shape of the Vulgate, commentaries, moral works, and also religious legends, lives of saints, and the like.

(4) The material and spirit brought in by the Teutons in the shape of their own old epics and sagas, with the myths which formed their basis.

(5) The Celtic feeling, traditions, and compositions which made their way into the répertoire of such countries as contained a Celtic population.

(6) The learning, literary matter, and literary art of the Saracens, whether introduced by way of Spain or by that of Sicily, and whether derived from Oriental or from Greek sources.

(7) Literary influences from the Greek world, including remnants of classical and post-classical compositions, mediaeval productions of Byzantium, and 
tales of the East which had been rendered into a Greek form.

It is difficult to disentangle these various threads, which interlace each other in complex ways, but on the whole the most satisfactory procedure will be to make a note or two upon each. Such notes will necessarily be brief to the point of mere hinting.

(I) It was, perhaps, to be expected that, with the decline of Latin culture, the "fittest" part of Latin literature to survive in the knowledge of the semibarbarized west should be that which lacked the highest artistic qualities. It is only with the dawn of the first Renaissance, which led up to and was assisted by the great Tuscan trio, that the true classics began to re-appear among the common reading of men of superior learning. Virgil, indeed, was not wholly forgotten, nor was Cicero, and in the age of Charlemagne there was promise of a much wider scope. But, unless with the piously inclined -and often even with them-the Dark Ages were more interested in scraps of miscellaneous information containing a spice of the wonderful, derived and garbled from Pliny, in stories with a similar spice of the marvellous and, by preference, of the licentious, such as are to be found in the Satyricon of Petronius and the Golden Ass of Apuleius, or in traditions of the art of love culled from Ovid and crudely transmitted. For those of a more serious turn there were the mild philosophizing of Boethius, the history of the Spaniard Orosius, and the encyclopaedic educational medley of Martianus Capella; and, for the religious, the hymns of Prudentius served as a model. Yet, though sparingly met, the 
reading of literary Latin never quite failed, and verses, for example, continued to be written as much in the style of Claudian as writers could command. Latin comedy was not unknown to the monasteries, since the German nun Hrotswith is found in the tenth century composing prose imitations of Terence. It is impossible, in the defect of our material, to tell with any precision the extent to which Latin reading was directly kept in vogue. Capella and Orosius, at least, were accepted as standard works, but in respect of the legends, stories, mythologies, and pseudomarvels of natural history, such matter as shows itself at the birth of the new literatures had in a large measure come back in roundabout ways and through other channels.

(2) It is more easy to name the chief Latin productions of the Dark Ages themselves. If we regard Boethius as the last figure in Roman literature proper, the series consists mainly - for the sixth century - of the voluminous writings of Cassiodorus, historical and educational; the informal History of the Franks by Gregory of Tours; and the work of the Goth Jordanes concerning his own people. To the seventh century belong the Christian and didactic Moralia of Gregory the Great, and the encyclopaedic Origines of Isidore of Seville. To these we must add two writers of Great Britain; the one, Gildas, who wrote in Wales, in the middle of the sixth century, his dolorous account of the conquest of Britain by the Saxons; the other, the Englishman Bede, whose Ecclesiastical History and biographical works belong to the eighth. The age of Charlemagne, with its vigorous encouragement of education, consolid- 
ated all the promiscuous learning of the time, in which style plays a part altogether subordinate to the multifarious contents. From a literary point of view the creations above-named are of little moment to our subject, except in so far as information and misinformation from this uncritical mass of material found its way into all the work of our pre-Renaissance writers. Their chief merit is that they kept the channels of classical influence from being completely blocked. 'We must, however, note one important innovation in literary form. This was the introduction of rhyme into Latin hymns. The exact source of the novelty is unknown, but it began as early as the fourth century, and, together with Arabic influence, it helps to account for the use of rhyme which became current in the neo-Latin countries before their modern languages produced a real literature.

(3) The Hebraic influence which came through Christianity is as obvious as it was far-reaching. Every step in the Christianizing of Europe meant the conveying, not only of new sentiment and new ways of regarding things, but also of new materials in the way of Biblical history, however distorted in perspective. From the new doctrines of self-mortification there grew legends of the saints; from the traditions of their sanctity, legends of miracles; from the persecutions, legends of the martyrs. Botl the Old and the New Testament already existed in a Latin form even before the more competent and authoritative version of Jerome (about $\Lambda . D .400$ ). It should also be observed that the Bible which was thus rendered accessible was then read, far more 
than in later times, as a book containing matter interesting in itself, and therefore to be utilized and recast in story, apart from its uses in theology. Meanwhile round the original Scriptures both the earlier and later "Fathers" built up large masses of comment. When we remember that in the Dark Ages it was the churchmen who kept alive literary cultivation and production, and that the Bible narrative, the legends, martyrologies, and Christian doctrines were conveyed to every mind by sermons and other agencies, it is manifest how extensive must have been the effect upon thought and matter before the newly forming literatures emerged. On actual literary art and style it is true that there could be but little palpable influence, until, or unless, the Bible came to exist and to be widely read, as it eventually did in England, in the vernacular. But of this something more will be said in a later section of this book.

(4) With the Teutonic invaders of France there came in the spirit of feudal relationship. For centuries this spirit survived. Combined with the Celtic exaltation which is so pronounced in the Arthurian legends, and also with the sentiments of Christianity, it became embellished into the well-known mediaeval conception of knighthood with its vows of utter loyalty and self-devotion. The way was thus prepared for the knightly, or chivalrous, romances which are to be described in the chapter on the literature of France.

But, besides this feudal spirit shown in the Franks, there had already existed among the Germanic tribes before their settlement in France or Britain an 
orally transmitted literature. Its form was epic, and its themes the superhuman exploits of heroes among scenes of slaughter and carousal, in contest with huge monsters, and under the dispensation of rude pagan deities, Woden, Thor, and the rest of the Teutonic pantheon. Between the fourth and sixth centuries this heroic poetry of Germany grows into appreciable form, and both the Franks of the Continent and the Anglo-Saxons of England bring with them their several portions. In Germany itself it is much later that the Nibelungen Lied is edited into a connected shape; but to England there came in the sixth century the epic legend of Beowulf, of which the source is to be found in events of southern Sweden and the Western Baltic dimly recorded. This poem was edited in Christian times, and with some Christian additions, during the literary flourishing of northern England in the early part of the eighth century. Another poem carried from the mainland by the Englecyn was the Song of Widsith (the Far-Traveller), a wandering gleeman who has much to say of the deeds and generosity of the Gothic and other German chiefs among whom he roamed "as his fate willed," and to whom he "unlocked his word-hoard."

In point of matter this Germanic contribution to Dark Age literature is perhaps of little account. But its vigour of action and strenuous temper did no little towards determining the virility of the French chansons de geste, which formed so large a portion of English reading in the pre-Chaucerian period. In point of form it is necessary to note that the Anglo-Saxon method of versification, based on ac- 
cent, alliteration and assonance, is naturally inherited from the German tradition. With very slight modification the method of Anglo-Saxon poetry is also that of Langland in his Piers Plowman of the Chaucerian age. Though this was subsequently abandoned by English poets in favour of the French system of rhyme and numbered syllables, the use-all the more artistic for being disguised-of alliteration and accent has survived as one of the chief formal beauties of all our poetry.

Whereas the Teutonic poetry, when it came in contact with Christianity in England or France, soon lost its characteristic themes, its mythology, and much of its savagery, the older matter and spirit still flourished among the pagan Norsemen, and were re-imported into northern England with the invasions of the Danes.

(5) More distinguishable and pronounced effects upon the literature of western Europe were produced by a backward invasion of the Celtic themes and temperament. There was much Celtic blood in northern Italy and in Spain, still more in France and the British Islands. When once the Celtic temperament emerged in literature it was sure of a ready and wide response. Perhaps no such emergence would have happened if it had not been that in the Dark Ages the Christian scholars-the only authors of that epoch-were especially cultured and ardent in Wales and Ireland. The racial and patriotic feelings of the British Celts were pathetic and intense, and, whether among those in western Britain, or among the emigrants to Brittany, the exploits of their race were celebrated in song marked 
by a high spirit of pride, as well as by a peculiar mysticism and a remarkable sentiment of chivalry and romance. The actual contributions of the Celts to our own literary making are the subject of brief remark elsewhere.

(6) The influence of the East during the period before the first Renaissance was of no small importance. The language through which it came, but not often the language in which it originated, was the Arabic of the Saracens, whether as invaders of Spain or of Sicily. It is precisely while the literary state of Europe was at its lowest that the Saracenic culture was at its height. Into Spain, where the Moors had established themselves in splendour and opulence, there followed all the learning of the Semitic East, in philosophy, natural science, and medicine, together with the literary forms of the Arabs and the music of their accompaniments. Though the western Saracens were politically altogether separate from the Caliphate of Bagdad, the literary language was common to the Moslem world, and men of learning and artistic gift-whether Arabs or Jews-were equally welcome at either end. In the reign of Abd-ur-Rahman, in the early part of the tenth century, there particularly flourished in Moorish Spain the light verse of love and its gay surroundings. Meanwhile Cordova developed what was practically a University, to which congregrated all manner of Oriental talent, and in which studies in science and philosophy were prosecuted with zeal. Nor was the diffusion of all this culture restricted to the Arabs or their Spanish subjects. Many Christians from other parts of western Europe sought a 
knowledge of mathematics or medicine at Cordova, nor were these severer accomplishments all that the visitor would acquire.

To literature proper the true Arabs would have contributed little. In their original home their poetry had mostly taken the shape of the qasida, a loosely connected ode, in which an introduction concerning the forsaken camping ground was regularly followed by reflections on the singer's love affairs, and these by thoughts concerning his desert wanderings, his steed, and finally his chief. Of most importance to us, perhaps, is the fact that this Arabic verse was in rhyme, and that short odes, or ghazels, of fourteen lines, appear to anticipate the sonnet, a form which arose in Sicily in a court frequented by cultured Moslems.

After the establishment of Islam, the new religion at first exercised a cramping effect, but the same fondness for rhyme (which, indeed, was associated with notions of sacred or magic power) introduced it even into the prose of the Koran. When the Saracen conquest had extended widely and included Persia, the superior culture of the Persians gave them, from about A.D. 750, a predominating influence at the court of the Abbasids at Bagdad. Arabic literature, therefore, widened its forms and themes, and its poetry now embraced lyrics of love and wine, satires and elegies, largely of Persian origin. Of this poetry in general it may be said that it is marked by a peculiar predilection for sententious wisdom in the shape of proverbs and aphorisms, and for fables and allegories which convey similar maxims. These, we shall find, appear in full force 
in Spain, where they are converted into part of the earliest literature in Spanish. For the collection of such fables the Arabs and Persians could reach a hand in either direction. From the west they could take the Greek fables of Aesop and convert them into the Arabic fables of Loqman; from the east they could gather the Indian fables of Pilpay (or Bidpai), translated first from the Indian Pancatantra into the Middle Persian (better called Pehlevi), and thence by Muqaffa into the Arabic Kalila and Dimna. In this collection the actions of the beasts serve subtly to convey to a prince rules of wise conduct, more moral than the later principles of Macchiavelli. The Orientals showed an equal passion for purely romantic stories, provided that they contained wonderful and magical occurrences, much prowess, and luscious suggestions of magnificence and pleasure. The Thousand and One Nights, better known as the Arabian Nights, form an immense body of such compositions, which have been perpetually translated and re-translated, and which are still among the standard books of the world.

But the Saracens were by no means sunk in sententiousness or frivolity. They were impassioned for philosophy and science, especially the sciences of mathematics, astronomy, medicine, and chemistry. For their acquirements in these directions they were indebted to the Greeks, and chiefly through the Syrians of Mesopotamia. Here Hellenism, introduced by Alexander, had grown into peculiar strength, nor was the Greek blood itself inconsiderable. From the Syrians the Arabs derived their knowledge both of Aristotle and of Plato, although, 
from their practical turn of mind, it was the Aristotelian philosophy which they mainly affected, and which passed into the famous Arabic translation of Averrhoes. Carried to Cordova, much of this learning, and particularly that derived from Aristotle, was disseminated through western Europe. The Arabic influence on thought, reflected from Greece, was therefore great. From a more purely literary point of view, we must reckon with the introduction of Oriental apologues and tales, although many of these, as will be seen immediately, come in also from eastern Europe through a Greek medium.

In point of form it is impossible not to conclude that the minstrelsy and poetry which prevailed in Moorish Spain contributed liberally to the fashioning of the troubadour poetry of Provence. The itinerant Arab minstrel was not welcomed solely by Moors; he played his part among the true Spaniards, and Spaniards themselves turned minstrels after the same fashion. The eastern, or Catalonian, part of Spain was in language virtually identical with the neighbouring south of France, and no border separated the Catalonian minstrelsy from the Provençal districts. In 1112 the Count of Barcelona became the ruler of Provence, and in his train followed all the poetry and song which had grown familiar in Catalonia. It is dangerous to attempt to decide the more and less of direct borrowing; but the manner of the troubadour, his rhymes, his themes of the tenso, the planh, and the morning and evening songs, so closely recall the machinery and devices of the Saracens, that the affiliation can hardly be denied.

(7) Direct effect of Greece upon Europe to the 
IVest was in abeyance from the fall of Rome till the Renaissance. Occasionally indeed, but very seldom, we hear of scholars who read some Greek, and Theodore of Tarsus actually visited and taught in Anglo-Saxon England in the later serenth century. But such influence of Greek work as appears during the dark and mediaeval times comes only in circuitous ways and from inferior writers of inferior matter. It for the most part appears in stories derived from the post-classical Greek romances, or from Oriental tales first translated into Greek and then recast into Latin.

Greek romance itself-beginning as early as the second century, but mostly produced at uncertain dates from the fourth century onwards-at once betrays an Oriental atmosphere. Its genesis is not so much in the Greek mind as in the eastern mind, with which the empire of Alexander had brought the Greeks into contact. The writers commonly hail from Asia Minor or Alexandria, and the scenes and adventures are apt to be Babylonian, Syrian, or Egyptian. Their chief features are much the same. A number of unlikely and inconsequent adventures, comprising separations and stratagems of lovers, travels, voyages, dangers, pirates, magic, murders, descriptions, and dreams, are tediously repeated with unessential variations. One of the first examples, it is true, deals with wanderings in the north and west, among Celts and Cimmerians. This is the Marvels beyond Thule of Antonius Diogenes. But the Babylonica of Iamblichus and the Aethiopica (or Theagenes and Chariclea) of Heliodorus have their mise-en-scine in the east, with events and wonders 
in the Oriental style. The latter work enjoyed a special vogue, and portions of its contents were not scorned even in comparatively late times by Italians like Tasso and Guarini, and Frenchmen like Hardy and Racine. This, together with the Leucippe and Cleitophon of Achilles Tatius, and the pastoral romance of Daphnis and Chloe by Longus, played no small part in the conception of the French sentimental romances of the seventeenth century, beginning with D'Urfé and carried on by Scudéry and La Calprenède. The work of Longus is on the whole the most important, since it contains the new element of pastoral setting and description and some novelty of simple sentiment. In the Dark Ages themselves we cannot tell how far these productions were known in any direct form in the west, but at least we know that nothing travels more quickly than stories. Another romance, with the usual elements of love and adventure, and with the addition of "recognition of the long-lost," was the famous story of Apollonizus of Tyre, of which we possess only the Latin version, through which the tale was passed westward. This work was favourite reading in the age with which we are here concerned. It was translated even into Anglo-Saxon, and later came in again as an English version of a French rendering.

Of a different character was the Barlaam and Josaphat of John of Damascus, an ecclesiastical writer of the eighth century. The story is derived from Buddhist sources in India. Though magic plays its part, the whole is naturally of a moral and theological turn. The mediaeval world found it vastly interesting, for after its conversion into Latin 
by Vincent of Beauvais in the thirteenth century, it passed into nearly every European language which could pretend to a literature.

Meanwhile, through Greek versions, there came in tales of purely non-Greek construction. Chief among these was the work known to more modern times as the Seven Wise Masters, originally an Indian production, styled the Parables of Sandabar. This was turned into Persian or Arabic, then into Greek under the name of Syntipas, thence, in the thirteenth century, into Latin as Dolopathos, and thence again versified into French.

All this material appears and reappears in the fabliaux of France, in the earliest novelle of the Italians, and naturally in Boccaccio.

Other productions popular in the Dark Ages, of special note as the storehouse upon which the French trouveres in particular drew for their classical cycles of romances (to be dealt with in the chapter on French literature), were those attributed to "Dares Phrygius," "Dictys Cretensis," and "Callisthenes." If we place the two former under the head of Greek work, it is because of their ascription to Greek writers and their possible derivation, at least in part, from lost Greek sources. They deal with the story of Troy, ostensibly from complementary points of view-a Trojan and a Greek. That there actually was some sort of history by Dares of Phrygia appears from a passage in Aelian; but the book On the Destruction of Troy, in which mediaeval reader's put their simple trust, is a Latin production of a date probably not earlier than the sixth century A.D., although it pretends to be a translation of Dares by 
the classical writer Nepos. Similarly an actual Greek Dictys of Crete apparently did write an account of the Trojan war and the Greek heroes, but the book in actual use was but a fourth-century production in Latin, asserting itself to be a translation. Portions of these two compilations were versified, transfused, and invested with an atmosphere of mediaeval chivalry, by Trouvères, including the NormanEnglish Benoît de Sainte-More, whom again Guido Colonna, in the thirteenth century, exploited for his Latin History of the Trojan War, a work which became the standard reference for "matter of Troy" as it appears in Chaucer, Lydgate (Troy Book), and Gower. It is not from Homer, but from these pseudoclassical accounts, that we derive such episodes as those of Troilus and Cressida.

For the cycle of Alexander the same generation of Trouvères and their English followers were indebted to a late Byzantine writer, who pretended to be the Greek Callisthenes, contemporary of the great Macedonian. In point of fact his History of Alexander is an imaginative mixture of passages culled from history with eastern stories and marvels. It is, of course, in a Latin version that this farrago became known to the authors of the romans.

We must not forget the vogue during these ages, devoted as they were to tale and apologue, of the fables of "Aesop." Of these there were in mediaeval times various versions and collections, some derived directly from the Latin Phaedrus, who had versified from the Greek; others from the later Greek remodelling by Babrius; others again from an Arabic collection, which combined a compilation of the 
Greek with a compilation from the Indian Fables of Bidpai (or Pilpay). One early version, of uncertain provenance, was that of King Alfred; and it was apparently a general massing of all this material which, after passing through German and French hands, became the famous Esope of Caxton.

To all that literary matter which pretended to classical antiquity the Middle Ages, entirely lacking historical perspective, gave the comprehensive name of "Roman." How freely that term was used, and how miscellaneous had been the sources of legend, is manifested in the strange medley of the thirteenth or fourteenth century, known as the Gesta Romanorum, in which fragments of classical history, legends of saints, and Oriental stories, are combined without the least notion of their relations or contradictions. To the Gesta every writer, whether in England, beginning with Chaucer, or in Italy, beginning with Boccaccio, had free recourse for the matter of his poems or his plots. 


\section{FRENCH LITERATURE AND ENGLISH}

$T$ will be remembered that the influence of the 1 literature of Greece upon that of England has been exerted in various ways, direct and indirect, and at various epochs; and that it continues still to operate upon us rather more than less, affecting both the matter and the form of what is written in our midst. The literature of Latin, again, has always exercised an influence on every generation, Latin forms and thoughts being imbedded in our English writings beyond all enucleation or analysis. The literature of mediaeval and Renaissance Italy, we shall find, had indeed much to do with shaping and polishing the literature of England during the three hundred years from the time of Chaucer to the time of Milton, but since the last-named period it has played little part in determining what our authors shall say, or how they shall say it.

Prior in date and influence to that of Italy comes the literature of France, with the debts in substance or in manner which we are bound to acknowledge to our neighbours across the Channel. Our purpose does not require that we should pretend to traverse the whole history of French literature. If we dwell 
upon a certain number of salient topics or famous names, it is because they in particular represent the chief types in the development of French literary history, and either directly or indirectly affect the evolution of our own.

France has, during civilized times, been politically and socially, as well as geographically, so near to us; Englishmen and Englishwomen have been generally so well acquainted with the French language and French books, that it is beyond possibility to determine exactly what effect French models have had and are having upon us, just as on the other hand it is beyond possibility to analyse exactly the effect which English models have had and are having upon France. But, without aiming at this impossible exactitude, we may at least make ourselves aware of such periods and manners of French influence as yield themselves readily to the student's survey.

It will be found that, though the influence of French literature has been felt in every generation, there are two great periods in particular during which the creations and the critical principles of Frenchmen have dominated those of our own authors. The one is the period between the Conquest and the rise of Chaucer; the second is the period which began in the seventeenth century sith writers of the age of Waller and Dryden, and continued till towards the end of the eighteenth century, that is to say, till the time of Cowper and Burns. Approximate dates are, perhaps, necessary here, and the following may roughly serve. From about the year I Ioo till about the year $13 \%$, and from about the year 1660 
till 1780 , England took its cue in many departments of literary work from the matter, the form, and the critical principles of contemporary France. Doubtless at all times there have been borrowings to and fro, but these are the periods when the borrowings have been most one-sided and most palpable. The interval from the maturity of Chaucer till the earlier part of the seventeenth century was more especially the era of Italian influence, introducing and supporting that mightier influence from pagan Greece and pagan Rome which began in what is justly styled the Renaissance. Again, since the latter part of the eighteenth century, the time heralded by Cowper and crowned by Burns, the English have emancipated themselves from direct literary imitation of the French, although, as is briefly stated at the end of this chapter, there have been no few currents of French influence upon various classes of our writers, and, from them, upon the reading public.

Let it then be repeated that two periods especially concern us-the period of the Norman and Plantagenet kings preceding and reaching up to Chaucer, and that period which embraces the literature of the reigns of Charles II, James II, William III, Anne, and the first two Georges; or, to put the latter period more plainly and more suitably in a literary connection, the age of Dryden, of the "Social School," of the comedy of Wycherley and Congreve, of the essays of Addison and the Spectator, of the verse of Pope, of the prose of David Hume and Samuel Johnson.

The former period corresponds to the era of influence from the Provençal Troubadours and the 
Northern French Trouvères, from the epic chansons de gestes, the several kinds and cycles of "romances," the allegories, fabliaux, and other creations of which we must take some special account. The second period answers in particular to the names of Corneille, Racine, Molière, Boileau, Voltaire, and of a number of famous French novelists, letterwriters, and critics. How and in what manner these authors came to tyrannize so completely and so long over English literature will require some terse statement. For the rest, in the period from the writers of the romans and allegories down to Corneille, and again in the period from Rousseau to the present, we shall speak of French authors only as links in the chain of French development in itself, with a passing reference to any value they may have individually for the literature of England.

The greater part of the land of Gaul-the modern France-was at an early date occupied mainly by Celts, akin to, though not precisely identical with, the present Bretons of the north-west corner of the country. There were also Germans in the northeast, and Euskarians in the south-west. Under the Roman empire the land was gradually overrun with Roman settlers, Roman merchants, and Roman soldiers, and Latin naturally became the official language, the language of high society, of literature, and of education.

The mixed people in process of time thus came to speak a provincial Latin, and to call themselves "Romans." In reality they were very far from being true Romans, and their speech almost was as far 
from being true Latin. It was both corrupted and also broken up into local dialects. It was, in fact, a blend of Latin with influences from the various native peculiarities. Early in the fifth century a body of Franks, a German people and speaking a German language, invaded the heart of Gaul and permanently held its northern half. It is from them, the Franks, that the whole country obtained the name of "France." These conquerors brought many a German word-mostly of war and feudalism -into the language of the conquered, and likewise hastened the corruption of their "Latin" syntax. The old Latin of culture became more and more widely severed from everyday speech, and hence "Romance," the corrupted language of these modern "Romans" of Gaul, was regularly used as a term in direct opposition to the old and literary "Latin." It came, in fact, to mean the vulgar tongue. It was about the year 800 that, in the northern half of Gaul, the popular or Romance speech was formally recognized. In the tenth century, the Northmen descended on much of this region, and became its masters. Meanwhile the southern half of Gaul, which had been subdued by other German peoples, the Visigoths and Burgundians, was forming its own particular corruption of the Latin, and, among the dialects which arose in that division, the dialect of Provence, in the south-east, took earliest shape and clearest predominance.

Before entering upon any account of "French" literature, we must remove from our minds the conception of France and French as they are, and 


\section{LANGUE D'OÏL AND LANGUE D'OC I4I}

try to see them as they were in the eleventh and twelfth centuries. North of the Loire are various provinces and a distinctly marked Romance language, the langue d'oul, or "French." A Celtic attachment, which has immigrated from Great Britain, exists in Brittany, much Norman blood in the north, and a Frankish influence has modified the Gallo-Roman staple. South of the Loire are other states, and, for the most part, another Romance language, the languı d'oc, or " Provençal," with leanings rather to an Italian kindred on one side, and a CatalonianSpanish on the other. Strictly speaking, the langue d'oc extended over the country south of a line drawn from about Charente to the Alps, while Provençal is properly the language of the south-eastern portion of that area. Corresponding to the two divisions of Gaul there arose two different forms and two different spirits of literature, one "French," one "Provençal." Later it was a joining of these two forms and spirits (though with a very distinct predominance of the northern) which produced modern French literature, or "French literature" in the ordinary sense; and it was both of them, though chiefly the northern, which largely controlled England during two centuries before Chaucer, and so contributed to the making of that poet and his age.

There is a fact too often forgotten by students of English writing and even of English history. It is that until Chaucer's time England was only a portion of the King of England's dominions; the rest was on the continent, in France. Under Henry II, King of England in the later twelfth century, more than half of modern France, namely, Normandy and other 
provinces north of the Loire, Poitou, Aquitaine and Gascony south of it, were part of an English or Franco-English empire. At the peace of Brétigny in I360, Poitou, Guienne, and Gascony were still left a portion of the realms of Edward III. This fact of the oneness of England and much of France is of very great importance to early English literature. The court and official tongue, and, in a large degree, the literary language, of England were in any case French. The intercourse between England and the langue $d$ ' oil, and (though less continued) between England and the langue d' oc, was, moreover, intimate and frequent. The writers and minstrels were, in a considerable measure, common to England and to both northern and southern France. No few of the writers belonging to old literature in French, e.g., Walter Map, and Benoît de Ste. More, had their homes in England; among them was Marie de France. The channels of communication were constantly open, and the current flowing and ebbing through.

A concise account must first be given of the two Gallic literatures, "French" and Provençal. Provençal flourished early, and enjoyed but a brief life. We may, therefore, trace this branch first, then the northern French, and afterwards compare and combine the two.

Though northern France had its song of Roland and other chansons at as early a date as the love lyrics of Provence, yet, if literature implies conscious art and system, Provençal composition is - with the exception of Anglo-Saxon-the first real literature 
of modern Europe; it stimulated Spain on the one hand, and Italy on the other; but it was in advance of either. It is earlier than Dante, and, although it is appreciably indebted to Ovid, and in some degree to Virgil, it is anterior to the influence of the classical forms or spirit of the first Renaissance. It began, helped by Moorish or "Arabian" impulses and lessons, in the eleventh century, enjoyed a brilliant existence for two hundred years, and died with the dying langue d'oc. Though it was never enriched and made immortal by the work of any one transcendent genius, it can boast a large number of composers possessed at least of talent and taste. Provençal verses became models for all neighbouring countries. Frederick Barbarossa in Germany, Richard Cœur-de-Lion in Anglo-French England, Alfonso II in Aragon, Frederick II in Sicily, these royal personages went out of their way to compose in the fashionable style and rhythm of Provence. They became, in fact, troubadours. The terms needs some explanation. A troubadour is not properly a wandering minstrel carrying a guitar. That itinerant minstrel is an inferior order of person, the jongleur (in Provençal joglar). He stands to the troubadour as the Anglo-Saxon "gleeman" to the "maker." The troubadour was the "finder," the poet, generally a noble, a knight, sometimes even a prince. It is no doubt true that the jongleur, who originally sang the troubadour's ditties, was fain, like other inferiors, to assume the higher rank, try his own hand at composing variations, and call himself a troubadour, and so the title became degraded. It is true also that the real troubadours frequently chanted their own 
songs of love and glory, and so helped to cause confusion between themselves and the mere jongleur minstrels. But the troubadour proper was one who travelled sumptuously mounted and attired, to be the honoured guest of châtelains and princes.

Nearly all this Provençal literature of three centuries of troubadours is lyric, not epic. It is generally singing, not narrating, and its theme is chiefly personal feelings. Rhymes, which had, it is true, been sparsely employed in monkish compositions in Latin, were then novel things in European literature, although long and universally used by the Saracens. The Provençal poets cultivated rhymes which grew more and more varied and complicated; with careful elaboration of soft and harmonious sounds they sang of two things, and almost only of two, to wit, love and glory, gallantry and chivalry in both senses and connections. The verses were love verses or martial verses, celebrating loyalty in love and valour in arms. As a class they are without pretension to any profoundness of imagination or to any sublimity. Their excellence is their music, not any translatable substance of thought. It must be confessed that the songs and subjects lacked variety; the same tricks of expression and "conceits," the same nouns and adjectives, the same situations, the same "fantastic sentimentality," would re-appear monotonously, and would inevitably suggest the artificial and unreal. One could hardly be expected to read extensively in the cansos, or love-songs, of those who called themselves the "gentle troubadours," without a feeling of satiety. "The serenade (serena), the morning greeting (alba), the dispute of 
lovers (tenso or joc parti), the lament (planh), which were recognized species of troubadour effort, inevitably suffered from exhaustion of material. Nevertheless one cannot but be impressed with the chivalrous idea of love which many of the Provençal poets professed, and according to which they nearly always treat that passion, vaunting a devoted tenderness and a delicate and sentimental worship. The influence of this idea, as still further refined anc ennobled in Tuscany, is palpable in the attitude of Dante towards Beatrice, and of Petrarch towards Laura; there are many traces of its influence in Chaucer and his contemporaries. Through the Petrarchist sonneteers it again reaches England in the Elizabethan age.

It must be enough merely to mention the names of Bernard de Ventadour, Bertran de Born, Pierre Vidal, and Arnaud Daniel, among famous troubadours. But a word may be said of that remarkable institution, the "Court of Love," to which a poem of Chaucer (or more probably of some one with a large share of Chaucer's mind) owes its conception and its title. During the later generations of the "gentle troubadours," the way to speak and think of love and gallantry was reduced to a system. It was made a science-called el gai saber, "the gay science"-which every poet was supposed to understand and to have at his finger-ends. One favourite form of poetry was the tenso, a dispute or altercation between troubadours upon delicate questions and scruples of behaviour and feeling in affairs of love. It became the fashion for noble laclies in those idle, rather frivolous, but doubtless not unhappy days to 
hold mock courts, in which poets sang one against the other, like opposing advocates; whereafter the court gave its decision, or arrêt d'amour, and awarded prizes to that troubadour whose arguments and verse were most in keeping with the code prescribed by the gay science. "Is it a greater grief to lose a lover by death or by unfaithfulness?" may serve as an example of the subjects particularly favoured in these poetical courts of the ladies of Gascony, of the Countess of Champagne, or of Queen Eleanor.

Such, briefly, was the genuine Provençal literature-lyrics of love and bravery, with here and there a pastoral, and here and there a poem of censure or satirical criticism. But true epics and romances of adventure, sustained allegories, witty tales of common life, they had practically none. For these we must look to northern France, to the land not of the troubadours, but of the Trouvères. Trouvere is the French form corresponding to the Provençal troubadour, and equally means the "finder," who is indeed the "poet." But in northern France there existed different social conditions and a different clime; there was also the sterner stuff which belongs to Franks and Normans, while in Brittany there was the Celt, with all his melancholy fire and imaginative and mystical emotion. The lyric literature of the north blossomed, indeed, somewhat later than that of Provence, and is largely an imitation of it. The romances of the trouvères are also distinctly infused with the ideas and style of the lyric south. Nevertheless the great mass of the poetry of northern France is of its own creation in both matter and spirit. It is the poetry of the epic, the allegory, and 
the tale; the poetry of the romance of heroic adventures, of satirical teaching, and of stories to amuse; in other words, it produced the chanson de geste, the roman, and the fabliau. It is in every way stronger than the creations of the south, in seriousness, in vigour, in variety, in invention. According to Ten Brink, prouesse, the masculine side of chivalry, is more northern, while courtoisie, the feminine sicle, is more Provençal. But the difference goes much deeper than any pair of terms can express it.

The old French poems of heroic adventure, blent with more or less of that other-world imaginative quality known as "romance," fall into three main cycles of subjects. They deal with Charlemagne and his Paladins (in which case they are more truly epic in character, and are called chansons de geste, a term properly thus restricted to incidents in supposed French history), or with King Arthur and his knights (together with the once independent legends of Tristram), or with classical heroes, whether of the Trojan legend or, like Alexander, of actual history. These three cycles have been named the "Carlovingian (or "French"), the "Arthurian" (or "British"), and the "classical" (or "Grecian"). Or we may make four by subdividing the last into "Trojan" and "Alexandrian." At the time of their composition the cycle which dealt with the classical subjects of antiquity was said to deal with " matter of Rome." All antiquity was "Rome," and all ancient heroes "Romans." We find, then, songs of Roland and Oliver, romances of Tristram or Launcelot, romances of Alexander the Great, and many more. Some ronans, called d'aventures, are independent of any 
cycle and make no pretence at all to be history. The twelfth and thirteenth centuries are rich in the poetical narratives which tell of heroic feats, or miracles of devotion and loyalty, mixed with much of the supernatural withal. This was the day of the Crusades, of conquests of the Saracens, single combats, adventures in distant lands, where dwarfs and enchanters, dragons and giants, were supposed to dwell; and nothing pleased the venturous barons more than to be told such tales to the music of the itinerant jongleurs. A further variety of these songs of exploit was the lai, which is too short and too lyrical to be an epic or a roman, and is rather the song of an epic episode. The allegorical poems - which they also called romans, as being similarly akin to epic and written in the vulgar tongue-long and tedious as they are to us, were not disdained by Chaucer, and gave the cue to several conspicuous works of the Chaucerians down to the sixteenth century. That most famous of all, the Roman de la Rose, was translated by our master of English undefiled. This poem, begun by Guillaume de Lorris as an "Art of Love," after the manner of Ovid (as filtered through Provence), was continued a generation later by Jean de Meung as a satirical miscellany of learning and legend. It is all about a lover who sought to pluck a rose, about his difficulties in reaching it, about the abstract qualities which help or hinder him, about personified virtues and vices, such as Dame Idleness, who lets him into the garden, Avarice, Meanness, Hatred, who stand in his way, Fair-Seeming, who has much to say in the matter, and numerous others. Thanks to these 
agencies, it takes that unhappy youth some 23,000 verses before he attains to plucking the object of his affections. Yet it was this reading which inspired the earliest efforts of our Chaucer, and which, in his first stage, he fell to imitating. It was this literature which the cultivated Norman English delighted hugely to hear. Allegorical, also, and purely satirical is the prolonged beast-fable known as the Roman de Renard ("the fox"), which enjoyed an immense vogue throughout Europe, and provoked countless imitations.

One chief species of composition, and a highly important one, yet remains. This was the fabliau, the amusing tale in verse, the one kind of writing to let us know that the world was not wholly made of doughty knights and gentle damosels. The fabliau is a tale of real or possible adventure in ordinary life, generally of a humorous kind. It is, in fact, a sort of novelette. Chaucer's Canterbury Tales are often fabliaux. From France the fabliau was borrowed by the Novellieri of Italy. It was taken up and developed by Boccaccio, and both directly from France and indirectly through Italy it made its way into the general stock of European narrative material. Had it not been for fabliaux, one might have thought that in those days there was nothing else for men to do but fight and love. Yet the great ordinary mass of mankind existed all the time, doing its sober work in towns and country places. And it was time for this great stratum to find recognition in bourgeois story.

Thus in northern France we have chiefly epics and romances of heroic adventures, allegories more 
or less satirical and didactic, and amusing tales; in southern France we have chiefly lyrics of love and chivalry. As time goes on, each half moves closer to the other, although during the whole epoch of the northern romances the Provençal spirit had combined with the Celtic to pervade them with a peculiar tone of chivalric sentiment. In 1249 the two geographical divisions became one kingdom. Before the middle of the fourteenth century the Provençal tongue begins to die, and its literature to perish. The story of French literature thenceforward is one and undivided.

While the troubadour and trouvère literatures were thus flourishing in the two halves of France, the cultivated circles of Norman and Plantagenet England found those literatures sufficiently adapted to their needs. The ordinary language of these circles was identical with that of the trouvères, and at the same time the English possessions in Languedoc, including the cultured centre Bordeaux (gained by the marriage of Henry II with Eleanor of Guienne and Poitou), brought the Court into direct communication with the lyrics of the troubadours. Henry's son, Richard Cour-de-Lion, was himself a troubadour and the friend of troubadours, in particular of Bertran de Born. But better suited to the Anglo-Norman temperament, and, of course, completely intelligible to the French-speaking barons and gentry, were the romances, lais and fabliaux of the trouvères. The work of the Norman Wace (Geste des Bretons) in I 55 was as much intended for England as for France. So also was the Roman de Troie (1 160) of 
Benoit de Ste. More, which included the story of Troilus. The French Saint Grael stories of Walter Map (1 180) and the lais of Maric de France (1210) were produced in our island, and were the common property of England and Norman France. The jongleurs wandered from baron's court to baron's court, and the stories of Arthur,

\author{
Of Greece and Troy the strongë stryf, \\ There many a man lost his lyf; \\ Of Brute that baron bold of hand, \\ The first conqueroure of Engeland; \\ Of King Arthur, that was so riche, \\ Was not in his tyme him liche; \\ How Kyng Charles and Rowland fought, \\ With Sarazens nold they be caught; \\ Of Tristrem and Ysoude the swete, \\ How they with love first gan mete; \\ Of King John and of Isumbras, \\ Of Ydoine and of Amadas; \\ Stories of diverse thinges, \\ Of princes, prelates and kinges; \\ Many songes of divers thyme, \\ As Engelish, French and Latyne.
}

Before French literature could make much further advance, it must pass, after that of Italy, under pupilage to the Renaissance. As in England of the fifteenth century, there is first a period of stagnation, and then one during which France is borrowing and assimilating to its utmost lessons in thought and style, in form and substance, from the lately recovered classical masterpieces of Greece and Rome, as well as from the Italian writers who first enjoyed and exploited these treasures. During these stagnant 
and growing stages of French literature it exercises comparatively little effect upon our own.

The Renaissance naturally reached France before it extended to England, and the Renaissance meant in France what it had meant in Italy, and what it afterwards came to mean in England, namely, the widening of the intellectual and moral horizon, broader knowledge and broader views, a shaking off of old and dry traditions. And therewith it also meant greater variety of subjects in literature and the reign of better models of thought and expression. The effect of the Renaissance on French literature was to draw the thoughts of authors away from the old monotonous round of romances and allegories, and at the same time away from the old monotonous expressions and phrases; to make them attack all interesting subjects of thought, and meanwhile to adapt and polish the instrument of language which expressed them. This it was which the recovery of the Greek and Latin classics accomplished for Italians, Frenchmen, and Englishmen alike, supplying them with new range and scope, with new patterns and principles.

But as in England, so in France, this new birth and literary reformation did not exercise its full effect immediately. In England it gradually culminated in the Elizabethan age, in France it only attained its full development in the seventeenth century. That is to say, it was actually slower of progress in France than in our own literature.

For a time, while the first influences of the Renaissance were being felt, the effect in France was, as in England, a severance from the old subjects and 
methods, without a full adoption of the classical subjects and principles. The classical influence acts as a solvent before it comes to act as a crystallizing agent. There is, in fact, a transition period, during which writing is left free to attempt various forms. If a man of natural genius arises in such an epoch, he will give us his natural self, and so may create us prose or verse which, despite a deficiency in knowledge, will be immortal through its own truth and strength. If on the other hand at such a transition period men who write are lacking in native power, they will write much worse when they follow no models and adhere to no principles. In England, during the transition from the epoch of Chaucer to the time of Wyatt and Surrey, there appeared no distinguished poetic genius, and, except among Scottish writers like Dunbar, little more than tiresome production. In France, on the contrary, there were two distinguished poets, Villon (fifteenth century) and Marot (early sixteenth). These were stimulated by the new ideas, but were not yet dominated by the new classical models. They were freed from the mediaeval shackles, and not yet fettered in the bonds of misapprehended and misapplied "classical " principles.

François Villon wrote during the latter half of the fifteenth century, and is principally known by his ballads, which were something quite new to French literature, and have, one may venture to say, remained unique therein. From the old artificial romances and allegories he breaks clean away. He is as original and independent as our poet Burns, whom, by the way, he somewhat resembled in per- 
sonal character. His merit, like that of the Greeks whom he did not know, lies in his truth, in the candid expression of his own personal emotions, in his naive confessions, in his sincere pathos. We all sympathize with emotions and confessions of this nature, and therefore Villon, like Burns, possesses a permanent and a universal value. And not only is he true in sentiment, he is clear and direct in his phrase, and musical in his verse.

Clément Marot opens the sixteenth century. He has been called the father of modern French poetry. If this means that he wrote with an ease and sprightliness, and a vein of urbane satire, which are usually associated with the esprit gaulois, but which skim rather along the surface of things, it is true. But if it means that he is the consummation of the Renaissance, and that the critical principles of French poetry were established in his time, it is without truth. For Marot, like Villon, is a poet and an artist without following the despotic rules which afterwards came to prevail in France, and he furthermore sought his themes rather in the old French subjects, the romances and the fabliaux, than in realms of classical antiquity. The Italian influence, however, touches him and leads him into pastorals, which, we must note, were known to Spenser.

Villon and Marot are both of the transition period, and not wholly of the Renaissance. They both fell short in one great respect; they lacked depth and elevation. This is a vice to which all French verse is prone, setting, as it does, so special a value on form; but it was the more discoverable in these two 
poets, because the rich intellectual nutriment of antiquity had not yet been assimilated by them, because their minds laboured under the intellectual poverty of mediaevalism, because, in other words, they lacked the substance with which the best ancient literature is crammed. Their poetry has many blossoms, but bears little fruit. Yet they mark one great step in progress. They are emancipated from the old mediaeval artificiality.

While Villon and Marot were thus emancipated, there were others during this transition time who were not by any means so. On the one hand they allegorized, like the trouvères, to the utmost; their subjects were obsolete and unreal; on the other, their language was trivial and their contents uneven. Verse literature seemed to need bracing and correction in the light of advancing study of the Greek and Latin masterpieces, and it is to the administering of such correction that we come in what is known as the Pléiade.

The Pléiade, or constellation of the seven stars, was the term applied to seven men of letters, who formed themselves into a coterie or league about the year 1550 , with the professed resolve of reforming the French language and French literary methods. The conception is very French. This cool manner of looking at language and literary expression as subject to definite laws of art, which may be codified by a league or academy, is contrary to English notions. Not so with the French. They have no desire for impulsive and perhaps erratic individuality. This is one of their clearest characteristics. Of the Pléiade the two greatest names are Ronsard, 
the poet, and Du Bellay, who was both poet and manifesto-writer. Their object, as stated by themselves, was to bring French literature nearer to the classical models of Greece and Rome, and to create a nobler form and use of the language for literary purposes. And while Du Bellay was to write his manifesto, Ronsard was to give a practical illustration of the theory, by himself composing odes and sonnets in the proper style. The attempt was bold, and it was successful. For fifty years all French literature "Ronsardized." Here are a few sentences of the manifesto concerning the Défense et Illustration de la Langue Française. "Our ancestors have left us our language so poor and bare, that it stands in need of the ornaments, and, so to speak, the features of other people. ... By what means can we hasten its development? By the imitation of the ancients. . . . Translating is not a sufficient means of elevating our vulgar tongue to an equality with the most famous. What must we do? Imitate! Imitate the Romans as they did the Greeks! . . . We must digest the best authors and convert them into blood and nutriment. ... You that mean to be a poet, read and re-read the Greek and Latin models. Then leave all those old French rondeaux, ballades, virelais, chants royaux, chansons and other such vulgarities (épiceries), which corrupt the taste of our tongue, and only serve to testify to our ignorance. Throw yourself on those witty epigrams in imitation of Martial! ... Distil with a flowing style tender elegies after the manner of Ovid and Tibullus!. . . Sing me some of those odes as yet unknown to the French tongue .. and let there be nothing in which 
does not appear some trace of rare and ancient learning."

We need not agree with all this breezy advice. It is impossible to re-create a language all at once. If there is not inspiration, there cannot be good poetry, though one may have infinite good models to follow. Nevertheless the new school was a success for half a century, and both Ronsard and Du Bellay, though often mechanical and often flat, have left a few imperishable sonnets and other pieces. Our own Elizabethans not only read Marot and his contemporary Saint-Gelais (who introduced the Petrarchan sonnet into France), they also read Du Bellay, who finally established the sonnet and at the same time served as a pattern for English writers. One writer of the Ronsardist school, Du Bartas, was a writer of real religious conviction, and his Semaine or Week of Creation, translated by Sylvester, gained no small currency in England.

What calls for particular notice in this connection is the deliberate way in which French writers and critics can contemplate and formulate the principles and methods of good literature. The English, to whom so much of French verse is cold and mechanical, may perhaps think that it is this same formulating which has done incalculable harm to poetry, a thing in its nature as incapable of regulation as are our emotions and our thoughts. But the French are of another opinion, and it is at least fair to say that, if writing by rules hampers the flight of genius and prevents creations of the sublime, it on the other hand checks the production of that utter doggerel which has been sc often inflicted on readers of 
English literature. We shall do best to complete at once the history of this formulation, and then retrace our steps.

Early in the seventeenth century flourished the man to whom first were due those definite and despotic critical principles which were fully developed by Boileau and which came to tyrannize in England after the restoration of Charles II, subsequently reaching their perfection in Pope and his eighteentl-century school. It is true that Malherbe represents a movement which was simultaneously proceeding in Italy, and was also being begun in England by Waller and his follower Denham. But he was destined to exert a peculiar influence. François Malherbe was by nature critic, and not creator. He, like the Pléiade, offers himself as a deliberate reformer of literature. His thoughts are fixed on style and its correctness. His notion of verses is that they should be " beautiful as prose," without any of the bold irregularities of a Pindar or the sentimental vagaries of a Petrarch. He measures words and syllables, toils laboriously over every line he writes, and prunes down metaphors and hazardous expressions with the cleliberate knife of cold reason. What he compasses is conciseness and preciseness of phrase, and what he revels in is the sense, not of a profound thought or keen emotion expressed, but of a technical difficulty overcome. He is the true parent of all that verse, in reality but brilliant rhyming prose, which prevailed in France for two centuries, and which also reigned in England for at least cne. It is he who taught Corneille and Racine how to form a verse, and Boileau how to criticize one. It was 
Boileau who passed on the word to our English Pope, Parncll, Gay, and Johnson. Dryden was cloubtless the intermediate step, but it is to Boileau that Pope expressly resorts. But for Boileau, Pope's Essay on Criticism would not have existed.

Nicolas Boileau, who flourished and dictated the principles of criticism in his Art Poétique during the life of Dryden, in the latter part of the seventeenth century, was long called in France the "lawgiver of Parnassus." There is little doubt that the title was justified. His bent and character were almost identical with those of Pope. He was a keen satirist, acute critic, and clever reviewer, but he was no true " poet." His avowed object was to remove uncertainty of taste and to establish criticism on a basis of mathematical finality, to set forth a positive doctrine of literary judgement. And what his doctrine amounts to is that reason and good sense must decide against all spontaneity of taste. This means that poetry must attempt no audacious flights of fancy, must restrain its metaphors, must avoid complexity, and be sheer, plain, good sense, admirably expressed. And who that has read French poetry thenceforth until the rise of Victor Hugo, or who that has read English poetry from Dryden down to Cowper, will not perceive that the result of this doctrine was disaster to poetry, and that it produced, as Matthew Arnold expresses it, instead of so many classics of our poetry, just so many classics of our prose, writing in verse? Poetry cannot be judged by "common sense," nor written by " common sense." It is an imaginative art, and therefore requires uncommon sense. 
When, after the Restoration, the second great influence from French literature came distinctly over England, it came in this shape, one which was, on the whole, to be regretted.

There is one particular department of French verse of the seventeenth century which deserves a special note for students of English literature. In this department there flourished between Malherbe and Boileau sundry minor poets who had their representatives and pupils in the English Court of the restored Charles II. These were the poets of amusement and diversion, the writers of society verses on the one hand, and of drinking songs on the other. The art of expression elaborated by Malherbe told on these. Voiture, with his vers de société, and St. Amant, with his Anacreontic poems, compose in a polished style worthy of the literary reform which Malherbe and Boileau brought to pass. When Charles II came back from France to England, his court was entertained by "society verses" and by convivial songs written on the French pattern. Such, among others, are verses and songs of Dorset, Roscommon, Sedley, and some of those of Waller.

Meanwhile, in prose, the productions of France were of much greater intrinsic importance. At the end of the fourteenth century the chatty chronicler, or historian, Froissart, had combined much of the naiveté and freshness of Herodotus with much of the narrative picturesqueness of Walter Scott. A century later, under the growing influence of the new thought, the conception of history has grown almost philosophical, certainly practical and judicial, 
in Comines. The full effect of the Renaissance, however, appears in three sixteenth-century writers of very different characters and spheres of work.

Amyot, the translator of Plutarch, is not merely famous for unlocking the treasure-house of that author to the French and thence to the English world; he also taught how the prose of the language should be written for biography or essay. Somewhat earlier-contemporary with Sir Thomas More-appears the learned, satirical, gross, jolly, pathetic priest, Rabelais, whose mock romance, the Life of Gargantua and Pantagruel, is still a classic to those who know how to discern, beneath all its terrible coarseness, its grotesque obscurity, and its deliberate buffoonery, the bold criticism, and wise as bold, of contemporary society, especially of religion and the church. In the freedom and range of his thought he embodies the Renaissance, but a Renaissance which has imparted vigour and freshness without having yet taught the lesson of literary form and proportion. Rabelais is like no one else, but he contains elements which recall the broader, comic side of Shakespeare, and others which anticipate the scathing railleries of Swift. Sterne, apart from his natural affinities with the earlier ecclesiastic, draws upon him liberally.

More pleasant reading, both for its sweeter matter and its ease of style, is the work of the Gascon, Michel cle Montaigne-a contemporary of Sir Philip Sidney-whose Essays, while the first example in that domain of writing, have remained unique in their kind. To the reading of Seneca and of A myot's Plutarch he confessedly owed much, but his concep- 
tion of the essay as an easy-going monologue of moralizing self-revelation is his own. He chooses a theme, begins to discourse in an amiable conversational way concerning it, rambles from it into side paths, plucking the flowers of quotation, and returns to it when it so pleases him. Meanwhile, his real subject is himself. Montaigne the writer is serenely contemplating Montaigne the man. He is submitting him, his tastes, views, habits, and feelings, to a friendly inspection, recorded in the easy style of a man of the world, which charms the reader as he might be charmed by varied and fruity talk. It charms him all the more because the self depicted by Montaigne is always in many respects the self of the listener, who feels all through that touch of nature which makes the whole world kin. For Montaigne is no narrow egotist or pedant. He displays a wide sympathy or tolerance, and he is no dogmatist. His motto was Que sçais-je? To Elizabethan England the Essays were well known, either directly or through the translation of Florio, with which Shakespeare was familiar. The Essays of Bacon, with all their unlikeness to Montaigne, are clearly indebted to his example. How far the Frenchman's influence has since extended is rendered incalculable by its very breadth and pervasiveness.

For the sake of easier apprehension we may now briefly review French poetry proper, noting its characteristics and its effects on the poetry of England.

Early French poetry, we have said, consisted of romances, of chivalrous adventures, allegories, and fabliaux. The nature of these troubadour and trou- 
vère compositions has been described. Till after Chaucer's day the romances and allegories of France flourished almost as well on English soil, whether read and sung in the original French or adaptedlike the Romance of Alexander or the Romance of the Rose-in English dress. Chaucer himself translated the Roman de la Rose, and otherwise made free use of the French material, including the fabliaux. His contemporary, Gower, is almost wholly a copier of the French, and, during all the epoch which is called the Chaucerian, authors known and nameless used the stock of mediaeval France as freely and as monotonously as the French themselves.

This was the first period of our debt. It passed away wholly with all other things mediaeval, with chivalry and feudalism, superstition and ignorance.

Then came the transition period to the Renaissance, with Villon and Marot, who are among the truest poets of France just because they wrote without a deliberate theory. To those two poets we English are, however, in no special debt. The Pléiade next began a conscious literary reform with a propaganda of its own, only to be further reformed in turn by the poet-critic Malherbe, who inaugurated the era of " correctness," of prose in poetry, which was consummated and legislated upon by Boileau. Thenceforth, until the early nineteenth century (the "romantic" period, when French verse is under the influence of England and Germany), French poetry is nearly all alike-clear, cleverly, often brilliantly expressed, graceful, eminently sane, but generally cold, matter-of-fact, colourless, often satirical, rarely pathetic, never deeply imaginative or informed with 
profound emotion. The prime characteristic of French poetry since Malherbe's time is that it is beautified prose. The prime characteristic of the French literary mind is its willingness to be disciplined and checked, to be rendered uniform by means of rules and precepts.

On English writing in verse this French literature of the "golden age," the seventeenth century, had effect in two chief departments-in determining the school of social verse-writers and convivialists at the court of the restored Stuarts, and in dominating the poetical ideals from Dryden down to Cowper, in producing, in fact, the so-called "correct" or "classical "school of English literature, the school which said with Pope

True wit is nature to advantage dressed,

What oft was thought, but ne'er so well expressed.

This school aimed at polished, condensed, sparkling expression of thoughts which should be reasonable and easily understandable. How defective is such an ideal of poetry needs little demonstration. The true note of the time is the treatment of mediocre - subjects in language which is the perfection of neatness and point.

Along with the development of classical verse, and of the more happily directed prose which is the chief glory of French literature, there was proceeding the development of the classical drama.

Dramatic performances in France began in the manner usual in all Catholic countries, namely, with representations of religious events, biblical or le- 
gendary, such as the Passion of Christ or the miracles of the saints. The "Mysteries" drawn from the scriptures, and the "Miracles" drawn from the lives of the saints, were in turn followed by the "Moralities," or representations of the contests of abstract virtues and vices, which formed a pronounced step in the secularization of the drama and in the encouragement of original plot. Into all these there was imported a liberal amount of comedy, frequently of astounding coarseness. The actors, from being churchmen, came to be the members of the guilds of trade. Next, a corporation of the law-students of the Palais de Justice, which had been established and vested with privileges at the beginning of the fourteenth century under the name of La Basoche, took up the moralities and developed them still more in the direction of comedies with ingenious plot and literary dialogue. To the Basoche is probably to be attributed the famous piece (of about the year I470) called Lazoyer Patelin, from which at least one reiterated phrase has secured immortality in the shape of Revenons a nos moutons. From the Basoche the drama of Paris passed to the "Enfants sans Souci," whose particular vein lay in the so-called Solies, a bold species of satirical and farcical modification of the Moralities. So bold, indeed, were these pieces, that it became necessary for Francis I to suppress them. By this date (which is near the middle of the sixteenth century) the revived study of antiquity begins to act directly upon the drama also, and members of the Pléiade turn first to the translation and then to the imitation of the drama of Greece. The latter was the course taken by Jodelle, whose 
Cléopatre marks the epoch at which the serious drama of France definitely bound itself in the chains of the "three unities," accepted Seneca for its model of style, and adopted the Alexandrine couplet for its orthodox vehicle of dialogue. Comedy meanwhile enjoyed more freedom, though taking its patterns directly and avowedly from Italy. Between Jodelle and the great age of the drama of Corneille, the stage, like so much besides in France, passed under the domination, partly of Spain, partly of Italy. The chosen models were the Spaniards, Lope de Vega and Calderon, or the Italian Trissino, of whom something is said in their proper places. It remained for the literary reformation of Malherbe to find the consummation for drama also in the work of Corneille.

Pierre Corneille, the author of Le Cid, Horace, Cinna, Polyeucte, and other plays of greater and less note, flourished about the middle of the seventeenth century (the time of our English Civil Wars and Commonwealth), and was followed by Racine, the author of Phèdre, Esther, and Athalie, and the contemporary of our poet Dryden. When it is said that these two dramatists possess in full the French characteristics, it is meant that they show all the French virtues of elegance, good sense, and polish of style, and all the French defects of servility to rule, coldness, and consequent monotony. There can be nothing more unlike than the typical drama of Corneille and the typical drama of Shakespeare. The Frenchman deliberately adopts the so-called "Aristotelian" and "classical," but really Senecan and pedantic, rule of the unities, of time, of place, and of action; that is to say, his plays contain the 
development of but one action, which proceeds in the same place and within a time equal to that of the representation itself. To these conventions, which can have no natural or divine right to call themselves "laws," Shakespeare and the Elizabethan dramatists are strangers. A Shakespearean play-described as "romantic" in antithesis to "classical"-carries us from place to place, from year to year, and embraces, if it so chooses, a number of loosely related actions and episodes. Its unity is the unity of a whole story, not of a situation or climax. Corneille, to use his own words, had an aversion to putting Paris, Rome, and Constantinople on the same stage. The result is that there is often no background of place or time at all. This was but one difference. Again, Shakespeare's tragedies are performed, if he thinks fit, with all their slayings, suicides, and mutilations full in the face of the audience. In the French theatre, as in the Greek, these actions are regularly perpetrated out of sight and are merely reported upon the stage.

French tragedy is mostly the working out of a moral situation. English tragedy holds the mirror up to manifold nature. The French tragedy is "heroic," it seeks to interest and to elevate the soul by heroic sentiments dramatically displayed. We meet with heroes who are altogether noble, and with the opposite characters who are altogether base. They are "ideal" personages, who do little else but deliver artistic declamatory speeches in the manner of Seneca. On the other hand, the English tragedy represents men as they are, with all their complexities, inconsistencies, and shortcomings. The French do 
not, or did not, understand the English drama any better than we understand theirs. They call it irregular and inartistic. Voltaire at one period declared Shakespeare "a drunken savage, without the least spark of good taste or the least knowledge of the rules." We, on the other hand, grow weary of the continuous and unrelieved progress of the one and only action, and of the vagueness of background and lack of individuality in "the ideal action performed by ideal characters." The French portray types, not characters. The great masters accepted a fixed architecture for their plays and fixed limitations to work under, and their merit is that, despite these cramping conditions, they produced works of so elevated a literary and so exalted a moral style. It is not meant that Corneille, Racine, and the minor dramatists were as much alike as larger and smaller peas. A manifest difference, for example, which renders the plays of Racine more generally interesting than those of Corneille, is that Racine chooses subjects which come nearer home to most human beings. He brings us into one part, at least, of the practical human world, the world of love. The fault of French tragic drama is excess of rule and restraint; the fault of English drama had, by the time of the post-Shakespeareans, come to be excess of licence and consequent bad taste bordering on absurdity.

In the midst of the French influence upon English literature, which set in towards the end of the seventeenth century - the only time when Englishmen as a body have shown a readiness to submit to a prescribed code of critical principles-it is not un- 
natural that the English drama also should copy the French. The imitation, however, was by no means good as such. The English tragedy of the Restoration aims at being "heroic" tragedy, turns declamation into rant and bombast, and ideal character into impossible perfection. Fortunately the copying in this region was of comparatively brief duration. Of those whom it affected Dryden was the least guilty. He came to a theatre which had been but newly opened under Charles II, after the Puritan tyranny, and, as with everything else under Charles, the theatre endeavoured to take its tone from France. Dryden had himself been largely influenced by French critical ideas. He did not, it is true, agree entirely with the French principles; nevertheless, he found submission necessary. On the one side he had before him the magnificent "romantic" and "irregular" drama of Shakespeare and the other Elizabethans, on the other the new heroic and "regular" tragedies of France. He attempted to combine the better elements of both, and failed through falling between two stools. That he was conscious of a deliberate choice is clear from his own words: "Let any man, who understands English, read diligently the works of Shakespeare and Fletcher, and I dare undertake that he will find in every page either some solecism of speech, or some notorious flaw in sense-many of their plotswere made up of some ridiculous incoherent story." He mentions in particular Love's Labour's Lost, Winter's Tale, and Measure for Measure, and he goes on to quote the classical rules concerning unity of action, with its "beginning, middle, and end," and the rest; and thereto he ackls 
as his authorities the names of French critics of the school of Boileau, the now unremembered Bossu and Rapin. He does not, indeed, admire the French coldness and monotony, and his own object, though not that of his contemporaries, was, as has been already stated, to combine the better elements of both the French and English style. It is a grief to note that, in keeping with this view, it was thought no literary sin at this time to mutilate and adapt the plays of Shakespeare till they more or less suited the current taste. Dryden's own dramas, Tyrannic Love, Secret Love, Aurengzebe, and the Conquest of Granada are largely indebted to French originals, and have fallen between the two stools. Whereas Shakespeare and Corneille alike survive, no one now can act, and very few care to read, the plays of Dryden. Another play which is of some repute, the Cato of Addison, would certainly either not have been written, or would have been a less cold and declamatory thing than it is, if Addison had not lived in an age when France was England's teacher in dramatic and other literary rules.

Of French comedy a different story must be told. It is impossible to mention the name of Jean Baptiste Poquelin, better known as Molière, the contemporary of Corneille and Racine, without feeling that we are naming the world's best writer of comedy pure and simple, next to Aristophanes. What Shakespeare might have"done if he had written comedies alone, we cannot tell. Wherever his mature plays offer us undiluted comedy, it is superlatively comic. Yet we do not think of him primarily in connection with Aristophanes and Molière, but rather as the 
writer of Hamlet or King Lear. If we named an English author whose genius in many respects recalls Molière, it would perhaps be Sheridan, the writer the School for Scandal. In Molière there comes out the best side of the peculiar French genius, the Gallic wit, the trenchant satire without brutality, the keen entertainment without vulgarity. Molière at his zenith makes comedy a work of art, and of refined art; a comedy which edifies while it delights, and which delights without appealing to the lower elements of our nature. It is a humorous feast of the delighted reason, not a pandering to a mere taste for "lungs tickle o' the sere." His Précieuses Ridicules is keen and killing criticism of the silly affectations of a literary coterie; his Bourgeois Gentilhomme slays the ignorant parvenu, and his Tartuffe the hypocrite.

This comedy, delightful now to read as it was then to see, could not but seize hold upon Englishmen of the Restoration times and later still. Molière was copied, adapted, translated by English writers, and that not merely for reading, but for acting purposes. Dryden translated L'Etourdi as Sir Martin Mar-all; Vanbrugh turned Le Dépit Amourenx into The Mistake; Wycherley offered The Plain Dealer as a version of Le Misanthrope; Fielding's MockDoctor is Le Médecin Malgré Lui, his Miser is Molière's L'Avare; Colley Cibber converted Tartuffe into The Non-Juror.

So much at least does English literature proper owe to French tragedy and comedy. Of the constant plagiarism and adaptation of French plays in modern times nothing need be said, since these 
things have been for the most part hardly literature in the proper meaning of the term.

Meanwhile French prose-writing, which had been of such easy simplicity in Montaigne, passed for a while under the bad influence of the Spanish estilo culto, and of the English Euphuism. This was the day of the Hôtel de Rambouillet and of the Précieuses, with their finical refinements and affectations of speech. In the subject-matter of literature the Spanish influence showed itself first in the Astrée of D'Urfé (I608), a wearisome and unnatural "pastoral romance," prompted by the Diana of the Portuguese-Spaniard Montemayor. To this work are to be affiliated the "heroic romances" of La Calprenède and Mademoiselle de Scudéry, who are shortly to be mentioned. As for the prose vehicle itself, apart from these vagaries of its use, it may be said that, ever since French literature reached its golden age in the middle of the seventeenth century, its characteristics have been much the same as those of French verse, namely, clearness of order, precision of statement, good sense of thinking, a triumph of reasonable and exact expression.

Our own literature of the later part of the seventeenth century, and of the earlier half of the eighteenth, which owes so much to France, is nowhere more manifestly indebted than in respect of that lighter prose which takes the shape of letters and novels, and of what would now be called occasional journalism. The French have always been excellent letter-writers and journalists, as well as admirable novelists. Even the inferior French work, such as Mademoiselle de 
Scudéry's interminable pseudo-romantic prolixities -the Grand Cyrus, or Clélie with its Carte de Tendre-and those of La Calprenède (Cléopâtre and Cassandre), was reproduced in England by writers of the calibre of Mrs. Aphra Behn, as well as exploited by Dryden and other post-Restoration dramatists. The novel of adventure, which we associate with the names of Defoe (as in Moll Flanders and Colonel Jack), Fielding (Joseph Andrews), and Smollett (Roderick Random), and which is known as "picaroon" or "picaresque," is no doubt ultimately derived from Spain, but its way into England was made through Paul Scarron, a French seventeenth-century novelist, and through his followers and literary heirs, among whom in the early eighteenth century is the renowned Lesage, the author of Gil Blas. On the other hand, that class of fiction which deals with character and its analysis, and which appears in English with Richardson, the author of Clarissa Harlowe and Pamela, dates from Madame de la Fayette, who lived a century earlier than he, although it is perhaps to his contemporary Marivaux that the Englishman is more directly under obligation. The first great exemplar of modern letter-writing, who, after Cicero and Pliny, taught Horace Walpole and Chesterfield how to pen epistles, and who inspired the more or less mock correspondence of Adclison in the Spectator, was Madame de Sévigné, a contemporary of Madame de la Fayette.

The seventeenth century in France is covered with prose-writers of clear reasoning power, pinnacled in Descartes' Discours de la Méthode and Pascal's Pro- 
vincial Letters, and with writers of essays, memoirs, novels, letters, criticisms, character-sketches, and "maxims" in all their various kinds. There is the essai, which enlarges on a theme; the conversation, an essay in dialogue, like those of Landor; the pensée, a miniature essay with narrower theme; and the maxime, a pithy sentence forming the cream of a pensée. La Bruyère, La Rochefoucauld, and St. Evremond, for example, are familiar names. For our purpose it is enough that these writers preceded our own Addison, Swift, Steele, and Johnson, and that English prose of the Queen Anne period and the earlier eighteenth century was fashioned by France as much as was our verse itself. And as the excellence of prose is perfect clearness and ease, the influence of France herein was wholly good, just as the prosaic influence of its verse had been mainly harmful.

In the same century stands, sui generis, La Fontaine, the fertile author of the famous stories and Fables, to whom Dryden, Gay, and Prior owe, besides the hint of form, no little suggestion.

In the eighteenth century French literature is of an inferior order, unproductive of things noble in imagination or of great dramatic works. At its best it is critical, not creative. Until André Chénier at the end of the century, it has practically no poetry to show, since neither the occasional verses of Voltaire, nor his epic Henriade, nor his drama Zä̈re, can properly bear the name. Wit indeed flourished in the epigrams and comedy of Piron, as it could hardly fail to do in French work of the lighter 
kinds; but it was not till the precursors of the "Romantic movement" of the nineteenth centuryfor which France was almost as much indebted to the English Byron and the German Goethe as to its own Rousseau and Chateaubriand-that creative poetry appears again with Béranger and Lamartine. The Romantic epoch itself is then embodied in Victor Hugo. So far as the eighteenth century is productive, it is in prose, and chiefly the prose of thought and science. The novel is represented in the picaresque Diable Boiteux and Gil Blas of Lesage early in the century, in the analytical Marianne of Marivaux, in the satirically destructive Candide of Voltaire, in the powerful character study of Manon Lescaut by Prévost, in the sentimental and picturesque Nouvelle Héloise of Rousseau and Paul et Virginie of Bernardin de St. Pierre, and in the social fiction of Madame de Staël. Of the effect of Lesage upon England we have already spoken. Marivaux appears to have distinctly influenced Richardson, whose Pamela otherwise bears a strange similarity to Marianne. But most congenial to the English mind, now on its way to the Romantic revolt, was the work of Rousseau and St. Pierre, in which the notion of a "return to nature" is the dominant note. St. Pierre was the disciple; Rousseau is the master, who, whether in the novel or in his Confessions, is the first writer in modern Europe to expatiate upon inanimate nature in connection with the feelings. How much of the "nature-worship" of Wordsworth and his age may be due to this example from France can hardly be estimated, but the name of Rousseau was a familiar one in 
England, and by him was sown much of the seed which our own revivalists watered.

Passing over the letter-writers and minor essayists, we come to the thinkers, the propagators of freedom of thought, commonly known as the philosophes. In this case the impulse came from the English Locke and from contact with, and personal observation of, the liberal circumstances of England, at that time the most advanced in Europe. The crop of French solvent ideas from these sources soon found its way back to our own country. In his Esprit des Lois, Montesquieu, a writer of remarkable wisdom, examines the natural basis and evolution of law and custom; the fertile but superficial Voltaire, in various "Letters" and essays, lends his powerful wit to the weakening of accepted authority, especially in religion. Subsequently, in order to crystallize the knowledge which forms the necessary basis to right criticism and reformation, there was undertaken the famous, if not very successful, Encyclopaedia, or Dictionnaire Raisonné of sciences and arts, under the direction of Diderot and D'Alembert. Falling into the revolutionary current, and being in direct association with the philosophes and Encyclopaedists, the eloquent and passionate Rousseau produced the Contrat Social, with its doctrines of equality and fraternity and its innovating theories of education, and the Confessions, in which he lays bare his own pettinesses, but with exquisite literary skill. As his follower must be reckoned Chateaubriand, who, so far as expression of temperament goes, passed on his mantle to the English Byron.

If now it is asked on what groups of our English 
BRIEF COXSPECTUS OF FREXCH LITERATURF.

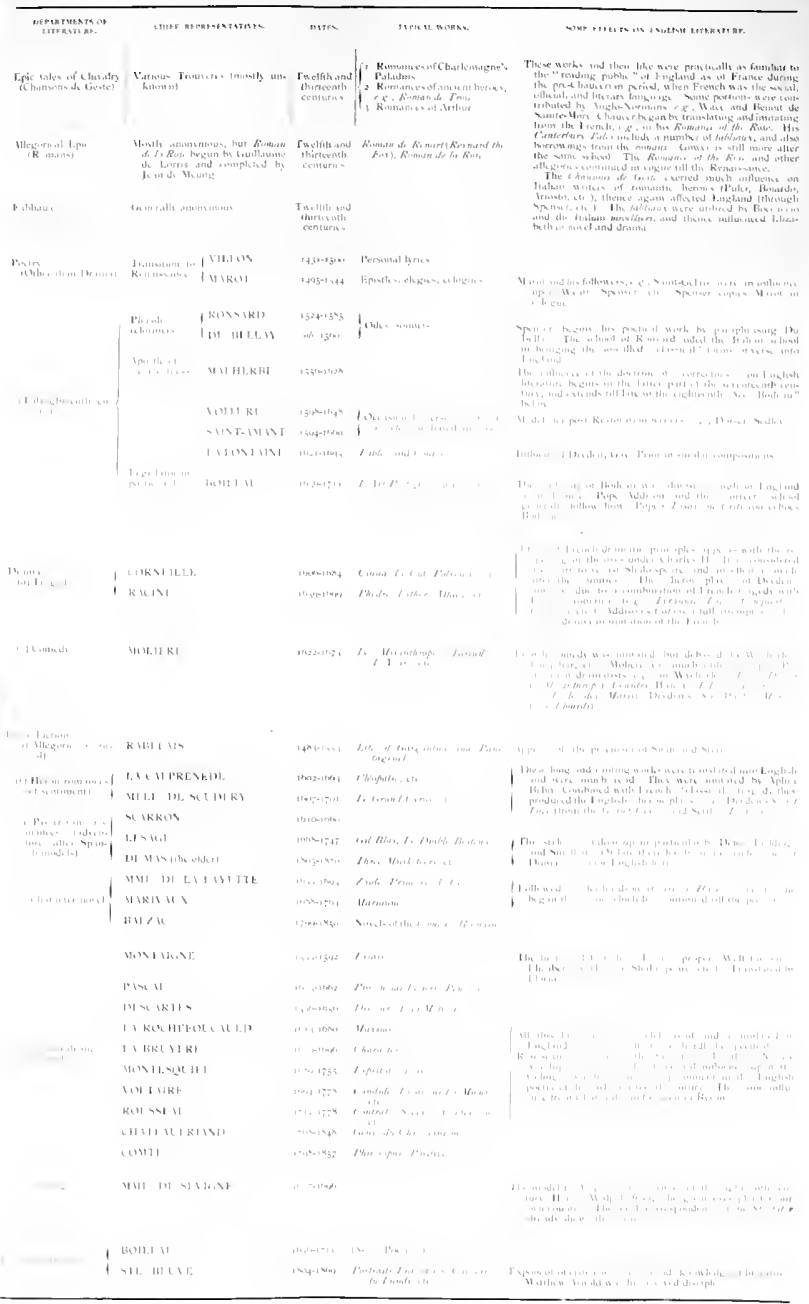


writers French influence is most pronounced and obvious, we should most safely reply that in preRenaissance times we must name Chaucer and Gower; then, after a gap of two hundred and fifty years, we may begin once more with Dryden and his contemporaries, the poctic " roisterers," Dorset and Roscommon, and the comedians Congreve, IVycherley, Farquhar, and Vanbrugh. In Pope and all his school the influence is manifest and conscious. It is present in Addison and Steele, and in the novelists Richardson, Fielding, and Smollett, different as they are; in the letters of IValpole and Chesterfield, and, in more or less measure, consciously and unconsciously, in all the writers of poetry, drama, letters, essays, journals and novels from about the year 1660 for a whole century.

Since that time the influences have been rather the other way, but those from France upon England may perhaps be enumerated as ( $I$ ) the elaboration of a sentiment for inanimate nature since Rousseau, St. Pierre, and Chateaubriand; (2) the absorption, and sometimes imitation, of French novels, such as Les Misérables and Notre Dame of Hugo, the revived picaroons of Dumas, and the naturalistic work of Zola; (3) the Positivist philosophy of Comte; (4) imitations or plagiarisms of French comedy, such as that of Sardou; (5) lessons from the literary criticism of Ste. Beuve, chiefly derived through Matthew Arnold; (6) stylistic lessons from writers like Flambert. 


\section{V \\ ITALIAN LITERATURE AND ENGLISH}

$7 \mathrm{O}$ Italy there always attaches a singular fasci1 nation. Its natural beauties, its historic associations, its ancient ruins, its mediaeval buildings, its collections of art-these things scattered thickly and in endless variety from one end of the peninsula to the other, from Sicily to Milan, from Genoa to Venice, make Italy the country of countries for the traveller of culture and sensibility, of enthusiasm for things splendid and beautiful.

This being so, it might seem a most inconsistent and regrettable fact that, while there are thousands who go, guidebook in hand, through the galleries of the Vatican or the palace of the Venetian Doges, or through that Florentine church of Santa Croce where they read the name of a Michelangelo or a Machiavelli on illustrious tombs, yet a very few have thought fit to look into Italian literature, to see if it perhaps contains things as worthy of regard as Italian edifices or Italian pictures. Few also realize that it is often impossible to understand Italian art without understanding contemporary Italian literature.

Time was when education was hardly a complete 178 
and liberal education if it did not include the knowledge of Italian and of the best thoughts of Italy. Time was when England was the pupil of Italy in letters, as it has largely continued to be in those other arts which are called "fine." At two periods, namely, first in the days of Chaucer, and afterwards for more than a century, from the time of Wyatt and Surrey to the prime of Milton, Italian masterpieces and Italian style were chief patterns to Englishmen, and Italian thoughts and subjects were borrowed without stint.

Doubtless Italy has had her day as our teacher in letters, and we look to her no more for inspiration or guidance in poetry or prose. Nevertheless it is a mistake to seek so little direct knowledge of what is meant by the names of Dante, Petrarch and Boccaccio, of Ariosto and Tasso, and of others well known to the ear. The study of writers like these in their own tongue would do much to remove the false impressions we are so apt to form of foreign peoples and their character. Literature is the "expression of the soul of a people," and the only sure way of getting at a people's soul is to study the expression of that soul in its literature. For instance, are the Italians a people of profound feeling, of much imagination, of high ideals of conduct? It is not travel which will readily tell us this, but a study of the emotions, imaginings, and moral conceptions which are revealed in their books.

The Italians are in but a partial degree descendants of the ancient Romans. The Romans proper never did fill much of Italy. To the south of Rome 
and in Sicily lay colonies of Greeks, at Naples, Reggio, Taranto, Syracuse and Palermo. To the north lay the alien and rather mysterious Etruscans in modern Tuscany. Still further north lay various Celtic Gauls along the valleys of Piedmont and Lombardy. And even in central Italy there were many tribes and many dialects, which were only brought by force under a common Roman empire and a common literary and official Latin tongue. The Romans did their best to weld all these diverse elements into a homogeneous people with a common feeling of nationality, common ideals and common customs. But at no time did one identical race or one identical dialect fill the peninsula of Italy.

With the fall of the Roman empire Italy became the prey of Goths and Lombards in the north, and later of Saracens, Normans, and Spaniards successively in the south. Modern times have seen these elements also combining as best they can into one people, with a national sentiment and a national soul.

The modern Italians are, therefore, descendants of ancient Romans and their kindred tribes, intermixed in intricate ways with Etruscans, Ligurians, and Gaulish Celts, with Goths and other Teutons, with Greeks, Spaniards, and a strain of Saracen. Nevertheless, among all these constituents, it is the Roman mental attitude which most prevails. Beyond doubt the literary ideal which possesses modern Italy is an inheritance from ancient Rome.

The modern Italian speech is the child of Latin, in the sense in which French and Spanish are the children of Latin; or rather, like French and Spanish, 
it is a new shape which Latin has gradually put on after hundreds of years of use and misuse. Perhaps a word must be said in order to explain the chasm between Latin literature and the Italian literature of Dante. At no time, even in the zenith of Roman prosperity, did all parts of Italy speak the same Latin, even if they spoke Latin at all. Local peculiarites of grammar and pronunciation were numerous and marked. Moreover, in the most golden days of Latin speech, that Latin which we know and learn was the language of a literary and cultured class; the Latin of the people was different and more free. As generations went by, and the Roman empire grew, the difference between the literary and the popular speech became wider and wider still, until the one was scarcely recognizable in the other. And when Italy in the Dark Ages was ravaged, unsettled, and dismembered; when little state sprang up here and little state there; when the literary and cultured class almost disappeared, the upshot was that the speech of the people prevailed, just as Saxon-English prevailed over Norman-French. In each district its own dialect became the law, so that people at Naples, at Rome, at Florence, at Bologna, at Venice, and at Milan, were speaking in distinct manners of their own, while recognized Italian language there was none. Dialects exist in all these places, and in many more, even to-day; nevertheless there is an orthodox Italian language, the "Tuscan speech with the Roman utterance," in which cultivated people endeavour to speak, and which is the only language recognized for serious literature. Many still imagine that it was Dante who made that language. 
On the contrary, no great literature can exist till the language is shaped. English had to be formed before Chaucer could come. An Italian tongue was necessary before Dante could build his masterpiece.

It appears at first a remarkable thing that the first literature which can pretend to any extensive influence in Italy was called "Sicilian." Moreover the ideal language of Dante was one which he called the "courtly language" - the lingua aulica cortigianawhereas no court existed in his Tuscan Republics. The two facts have their relation. Until late in the twelfth century Italy, having no recognized language, had produced nothing. Meanwhile the southern half of France had been for several generations ringing with the musical voices of the Provençal troubadours. Yet Italy, except for some troubadour influence in the north, was silent. But about the year I 220, Frederick II, of the "two Sicilies," had gathered about himself, in his rich and luxurious court at Palermo, scholars and men of refinement from all parts of Italy and Provence. At his seat, where cultured Saracens were numerous, and their artistic tastes in strong evidence, Provençal troubadours were to be found rhyming their dainty and harmonious songs of love and chivalry. "Sicilians" and others, gathered from the rest of Italy, took the key from these, and in Sicily sprang up for the first time in Italy a definite form of poetry composed in a popular speech instead of Latin. It is a love-poetry, which, in kind, is copied from Provence, aiming solely at a fine air of style and harmony of verse, and caring nothing for variety of subject or for originality of thought. There are the same trite 
comparisons, the same threadbare reflections, selfcommunings, and self-pityings. But the language employed was the Italian of the court, an eclectic diction, polished and regulated, and known as the lingua cortigiana or lingua aulica - the "court language." To the Italians assembled in Frederick's dominions this diction became the model for literary speech. Any who composed in it were "courtly" makers" in "Sicilian."

After the decline of Frederick's power in the south, it was Florence, Pisa, Lucca and the Tuscan communes that possessed the chief vitality and influence in Italy, and it was these that chiefly carried on the literary tradition. But the Tuscan dialect, like the East Midland English, was the most central. Its peculiarities were therefore the least pronounced among the dialects of the peninsula. The Tuscans readily formed from their own dialect a "courtly language" similar to that of the Sicilian poetry, and it was to Florence and its neighbourhood that Italians came to look for the choicest literature, as they looked for the most vigorous commerce. The custom of turning literary compositions from the local dialects into Tuscan as the fashionable language-the process called Toscaneggiamento-had begun before Dante wrote. And when Dante had written in Tuscan that monumental and immortal work, the Divine Comedy, it was inevitable that Tuscan should remain for all time the one and only language of ambitious Italian composition.

The first promptings to any Italian literature thus came from the graceful and musical, but often sickly and always artificial, poems of the troubadours 
whether clustered about Frederick or brought by visitors to the northern courts of Milan, Ferrara, or Verona. The contribution of Italy itself had so far been the sonnet form, invented in Sicily and destined to play the most important part among all Italian lyrics. The ideal erected had been one of polish, not of thought, and unhappily for the most part this suited the Italian genius only too well. But fortunately for the literature of the peninsula, there came very early the man to whom life was real and earnest, and to whom writing meant the expression of things intensely serious and vital.

Dante Alighieri was born at Florence in 1265 , and died in exile at Ravenna in $132 \mathrm{I}$. The first great writer of Italian is its very greatest-a name to be written with those of Homer and Shakespeare. It would require a volume to speak adequately and with illustration of the profound impression of nobility of character which he leaves upon his readers, of the vast reach of his imagination, of the startling vividness of the visions which he creates, of his master-power to make simple words tell just what he sees. To read the story of his life and times is a romance in itself. To place oneself in that Florence of six centuries ago, where Guelfs are conflicting with Ghibellines and "Whites" with "Blacks," where the burghers are at one moment filling the streets with songs and gay processions and pageants, and at another moment with the shouts of fighting and scenes of murder; to see among these same burghers the firm-set face of the future poet Dante, as he goes out to battle at Campaldino; to see him sitting as a magistrate of the 
city, and then again driven into exile and wandering, with a price upon his head, to Verona or Ravenna -it is tempting to dwell upon such visions, but the temptation is one which we must resist.

Dante is a figure in the literature of the world, not of Italy alone. Like Shakespeare, he began with the lyric work dominant in his age. Like Shakespeare, he therein revealed a power beyond his contemporaries or predecessors. His sonnets and Canzoni are indeed limited by the prevailing conventions of that style, but from him they gain a pure nobility of feeling and an intrinsic weight which no Provençal had displayed, and to which the best Italians had but striven. But to the world at large he is the author of the Divine Comedy. His readers, not he himself, called it the "Divine," both because it deals with things heavenly and mystical beyond all ordinary vision, and also because it transcends all other works which bore the name of "Comedy"-divine in its subject, divine in its execution. Dante himself called it Commedia. He knew nothing of the correct distinctions of true drama, for none existed in his day. To him commedia meant a medley, with a happy ending, something written in the vulgar tongue, not aspiring to be an epic, like that of the great master Virgil, but written in the middle style. The poem, as a fact, is no more a comedy than Paradise Lost is a comedy. Yet the title is his own and is indefeasible.

The Divine Comedy is a work which stands alone in literature, without a distinct prototype and without a worthy follower. The fact that Homer had made Odysseus descend to the shades, and that 
Virgil had done the same with Aeneas, accounts for the shape or machinery, but for no more. It is a work involving the most stupendous materialsno less than an epitome of contemporary thought, belief, mysticism, aspiration, passion, historyand handled with stupendous unconsciousness of mastery.

On the face of it, it is a narrative of a journey taken by the poet through Hell, through Purgatory, and into Paradise. In Easter week of the year I 300 , Dante is led by Virgil (who to the Middle Ages had strangely enough become the incarnation of this world's wisdom) down through the concentric circles of Hell-a funnel-shaped abyss within the centre of the earth-and descends step after step to greater and greater horrors. There he sees the gluttons wallowing in fetid mud, and the leaders of heresies burning in half-opened tombs; he sees the sinners of avarice and of prodigality suffer together with mutual revilings; he sees the steady rain of burning flakes of fire; he is amazingly fertile in other agonies for unrepentant or unshriven sinners. Then, from the Inferno, under the self-same guidance, he mounts to the light and ascends the mountain of Purgatorio, which rises like a cone, plane after plane, in seven tiers for the seven deadly sins. Here the souls that are being purified are suffering penances, which grow less and less awful as we approach the summit. On the summit itself is the Terrestrial Paradise. Further than that Virgil, the pagan poet, may not go; but Beatrice, Dante's lost love and his emblem of Christian faith, comes down to meet him, and together they rise in spiral rings of flight, upward and upward 
through glory after glory, till they reach the true Paradise, and stand in the presence of the Beatific Vision.

There is something awe-inspiring in the very contemplation of a subject so vast: yet Dante combines and handles all these mysteries with such a vivid realistic power that the last suggestion to rise in the reader's mind is any suspicion of grotesque, still less of futile, extravagance. His pictures are intensely vivid. His creations live. It would be no wonder if the good people of Verona really pointed him out in awe, and said, "Yonder is the man who has been in Hell!" A pictorial artist could scarcely exhaust Dante in subjects for paintings. And, with it all, his mere language is as simple and direct as was ever used by a poet's pen. It is so far Homeric. Almost the mere noun and verb suffice to say what he has to say, and yet, somehow, that same noun and verb combine into a sweet and majestic harmony, which fit the sublime subject as the "organ-voice" of Milton fitted his. We must, of course, make all concession to the ignorance of his day and the unattractive subtleties of the philosophy. These may often affect our interest, but they take nothing from the poet's genius.

Such was the narrative on the face of it. But the narrative is only the cloak for an allegory. Dante, unlike most other Italian writers, was a profoundly pious, and not merely a pietistic man. Moreover, his mind was stored with all the theology, science, and philosophy of the time, and he meant his work to have another and a deeper interpretation. In the Inferno and Purgatorio he represents the moral 
passage of man through life, learning to see its vices and their punishments, descending through them, and thence again mounting through selfmortification and cleansing fires upward to moral purity and wisdom. Virgil is the embodiment of moral philosophy; and so far moral philosophy can guide us. But Beatrice is the personification of Divine philosophy, the heavenly wisdom of theo$\operatorname{logy}$, and it is this which is required to bring man to the full beauty and beatitude of perfect holiness. That, on the one hand, so many should read the narrative as narrative, and be awed and fascinated by it, while they miss, or are unconcerned with, the allegory beneath; and that, on the other, the allegorical interpretation should not obtrude itself, and yet should be so clear and so symmetrical when discovered, is a superlative token of the poet's extraordinary genius.

There had been nothing really like this poem before, and there has been nothing since. We cannot explain away the original genius of Dante. Before him Italian literature had nothing but the amatory effusions of the Provençal-Sicilian type, insipid songs, laboured and affected sonnets, and some crude visions and allegories. From these the Divine Comedy utterly departs. All that it can be said to owe to the writer's times and his nation is the vivid realistic way in which spiritual conceptions are apprehended. The tendency which had been awakened by St. Francis of Assisi and St. Dominic had become general in Dante's day, a tendency to make material and visible, in symbols, in painting, and in acting, all the mysterious things hoped and 
feared in religion-a tendency to picture the details, the scenes, and the personages in Heaven and Hell -a tendency in which we do not share, and which sometimes shocks the weaker brethren when they read the Divine Comedy.

There is one other topic to be considered, which must keenly interest both readers of Dante in particular, and students of literature, including English, in general. Before his great masterpiece, Dante had written a work in which stately prose alternates with grave and stately sonnets. This was the Vita Nuova (or New Life), a work full of a profoundly touching, if quaint, nobility of manner, and one which places Dante more humanly, so to speak, among the writers of his time. His sonnets, we have said, are a prelude to greater work. They are the outcome of his era. The attitude towards love comes from Provence, and the sonnet from Sicily, while a certain allegorical metaphysics had been imparted by the Italian Guido Guinicelli, who had combined with the troubadour spirit the philosophic learning-such as it was-of Bologna. Dante had contemporaries, Guido Cavalcanti and Cino da Pistoia, who composed sonnets in a vein closely resembling that of the greater master. And in all of them the treatment is of one and the same thing-love.

In a previous chapter we have spoken of the conventional theory of that affection as established in Provence, and have anticipated its connection with the immortalized Beatrice of Dante and the Laura of Petrarch. Woman, it will be remembered, had been sublimated into something half divine, an object of a distant devotion, shrouded in a scmi- 
religious haze. Following the Provençal fashion, every Tuscan poet-putting, it is true, into his work a finer and graver spirit than that of his Provençal models--felt bound to devote himself, or to profess to devote himself, to some such ennobling object of affection. To that real or imaginary being he addressed his sonnets, from her he sought inspiration, by the ideal of her he guided his life. We shall find this phenomenon in its completest form in Petrarch, from whom it passed to our English sonneteers. Sometimes the sentiment was absolutely real, as real as the Rosalind of Spenser's Amoretti. We cannot but believe that in the first instance it was so with Dante, when he wrote of Beatrice in his Vita Nuova, possibly even when he commemorated her in the Divine Comedy. We cannot but believe that he loved a real Beatrice de' Portinari, whom he first saw at nine years of age, with a pure and elevated sentiment, and that he encouraged the sentiment as the means of uplifting and stimulating his genius and his soul. And we must believe that he is in earnest when, after her death, he makes her not only the type of all that is best in womanhood, but converts her into an abstract emblem of celestial wisdom. There is the very sound of truth in the words wherein he tells us of their first meeting. Rossetti translates them thus: "At that moment, I say most truly, that the spirit of life, which hath its dwelling in the secretest chamber of my heart, began to tremble so violently that the least pulses of my body shook therewith, and in trembling it said these words: "Behold God is stronger than I, and he shall reign over me.'" And after her death he writes: 
"It was given unto me to behold a very wonderful vision; wherein I saw things which determined me that I would say nothing further of this most blessed one, until such time as I could discourse more worthily concerning her. And to this end I labour all I can, as she well knoweth. Wherefore, if it be His pleasure through whom is the life of all things, that my life continue with me a few years, it is my hope that I shall yet write concerning her that which hath not before been written of any woman. After the which, may it seem good unto Him who is the master of grace, that my spirit should go hence to behold the glory of its lady; to wit, of that blessed Beatrice, who now gazeth continually on His countenance, who is blessed for all ages."

Of Dante it has seemed necessary to speak at this length because he is so incalculable a proportion of Italian literature. While other writers of Italy can be placed in general categories, Dante's Commedia must remain for ever by itself. So far as he betrays himself Italian, it is that, like all Italians, he is a vivid realist of pictures, cultivates a literary style of finished art, and possesses by nature a strong vein of irony.

Francesco Petrarca is accorded a rank second only to Dante among Italian poets. Perhaps in our primary object, which considers the influence of Italian literature upon ourselves, he is of more palpable consequence than Dante himself. For though Dante did indeed set modern Europe a great example, a model of sublimity in literature; though he did indeed supply English writers with many a 
thought and phrase; though Chaucer made borrowings and translations from him-as, for instance, in the story of Ugolino; and though he influenced the early part of Milton's Paradise Lost in a degree which we cannot exactly estimate, nevertheless his influence is comparatively indirect. But Petrarch is the writer to whom our English "courtly makers" and sonneteers directly and admittedly owe the conception of their literary form and tone, from Wyatt and Surrey and Sidney down to Rossetti and Elizabeth Barrett Browning. It is to the existence of Petrarch's sonnets that Shakespeare's owe theirs. Vast is the influence of a man to whose example is due at least the form, and often more than the hint of the matter, of the sonnets of our poets, great and small, for five hundred years. Nor was his influence confined to the sonnets. Chaucer borrowed love-songs from Petrarch, and Spenser learned his art of writing in translating a Petrarchan canzone. The effect of Petrarch was moreover cumulative, inasmuch as the French sonneteers, like Saint-Gelais, Ronsard, and Du Bellay, who borrowed from him, were themselves in turn imitated by Spenser and other English writers.

Petrarch, who was born in 1304 , and lived for seventy years, was both a poet and a scholar. He cared, in fact, more for his Latin writing in an epic like Africa, and for his collections of Latin MSS. than for those Italian poems which have made him famous to all Europe. We may render him hearty thanks for the immense help he gave towards bringing about the Renaissance; but we are here concerned with him only as the poet who expresses the 
Italian mind and expands the literature of England. Petrarch is the poet of love. He is the heir of the Provençal lyrics of chivalrous idealizing devotion. But his Laura is set upon a more human plane than Beatrice. The Laura de Noves, whom Petrarch first saw in the church at Avignon in the year ${ }_{1327}$, and to whom he addressed some three hundred sonnets, was his inspiration, as Beatrice was Dante's. "I owe to Laura all that I am," he asserts. "She made to bud forth with the noblest sentiments all the seeds of virtue which nature had sowed in my heart." Here we meet explicitly the accepted Italian attitude, as we met it in Dante, and as it was afterwards adopted -though with a change due to time and race and circumstances-by our English Surrey, and even by Shakespeare. Beatrice was a woman seen through all the grave piety and theology of Dante's serious soul; Laura was a woman seen through a Platonic atmosphere which the humanist Petrarch was adopting from the Greek revival. Yet Laura, though an inspiration, is only a real woman; she does not become refined away, like Beatrice, into a mere personincation of some abstract motive force. Petrarch's sonnets are poems to Laura, so many polished gems, so many keleidoscopic aspects of a true and pure passion, of the fluctuations of hope, despair, surprise. $\mathrm{He}$ is an artist in words and in verbal music. He uses no artificial ornamentation, and he scarcely ever falls below himself. If taste, delicacy, and refinement, combined with ingenious fancy and with a purity of thought which spurns all vulgarity, can make a poet, Petrarch is a great poet. And it is no wonder if sonneteers of all nations have made him 
their model. Nor is it much wonder that, after the exhaustive manner in which he treats of the phases of his passion, its vicissitudes, and its inward and outward experiences, there was little room for novelty on the part of any but a more than ordinary genius.

After Dante there is one thing we shall never find in Italian poetry, and we do not find it in Petrarch. We shall find taste, melody, beauty of expression, descriptive power, but we shall not find deep passion, uncontrollable rapture, soarings of sublime inspiration. Yet, for what Petrarch's sonnets are, they are perfect. His Canzoniere contains works of graceful thought or of tender feeling, of brilliant and polished expression, such works as a more fertile Tennyson might have written in that age; but they have no claims to be more. The impression, however, must not be left that Petrarch's poetry was all in sonnets. To this Sicilian form he joined a series of larger and freer Canzoni after Provençal example, and also Trionfi, or allegorical visions, dealing more after the fashion of Dante with love, death, chastity, and other abstracts.

From the Divine Comedy, through Petrarch, we come down to the Human Comedy of Boccaccio. Giovanni Boccaccio, the younger and more worldlyminded contemporary of Petrarch, theson of a Florentine merchant and a Paris grisette, educated at Naples and domiciled in his maturer years at Florence, is best known as the author of the first great prose work of Italy, the Decameron. In the year I 348 a terrible plague befell the city of Florence. Boccaccio, after opening with a powerful description of this 
pestilence, represents seven young ladies and three cavaliers as retiring to a delightful villa outside the walls in order to escape the contagion and their responsibilities, and to pass the time in idleness and amusement. Each of the ten persons relates ten stories, and thus we obtain a hundred short tales (or " novels," as they then called them), tales pathetic, sportive, or licentious. IVe are not greatly concerned with these stories; they are not original, but are taken from current recital, from Oriental sources, from French fabliaux, and from scattered productions or collections of insignificant Italian writers, such as are found in the crude shapes of the Cento Novelle. The notion of a series of stories strung into some sort of connection with each other is as old as the Book of Sinbad or the Seven Sages. Boccaccio's chief merit is that he wrought such stories into artistic tales full of the varied life of his time, and gave them literary shape in language pure, elegant, and sonorous, if, perhaps, often too diffuse. It is he who sets the example for his immediate follower Sacchetti and for those novels of Bandello or Cinthio which were current in English in the Elizabethan age, and which so often supplied our dramatists, including Shakespeare, with plots. It particularly interests us that the plan of Chaucer's Canterbury Tales, where each pilgrim is to tell the same number of stories, is directly or indirectly borrowed from Boccaccio, as indeed are some of the tales themselves, besides hints hard to specify. Gower's Confessio Amantis is under the same kinds of obligation.

In this work Boccaccio shows the usual Italian love, and also power, of depicting in words what- 
ever the eye sees, a love and power which recall the Italian fondness for realistic painting. There is in the Italian genius at all times this same quality. In Ariosto or in Tasso, as in Boccaccio, there appears this affection for word-painting, always skilful and complete, but often carried to excess and satiety.

Meanwhile, for students of English literature, there is other work of Boccaccio's which possesses no small importance. His two heroic poems, La Teseide and Filostrato, were the source of Chaucer's Knight's Tale and his Troilus and Cressida, as well as of all the compositions for which these have served as models. La Teseide is the story of Palamon and Arcite and their rivalry for the hand of Emilia; and Chaucer, Fletcher, and Dryden are among the English writers who have handled this theme. Filostrato is the story of Troilus and Cressida, and to compare Chaucer with Boccaccio is to see how different is the characteristic Italian light-hearted and rather cynically objective contemplation of the struggle of innocence and vice, from the English tendency to the dramatic and subjective realization of the pathos of love and suffering. For other copying of Boccaccio it may be enough to refer to Lydgate's Falls of Princes and to the Mirror for Magistrates (I 559) based on the De Casibus Illustrium Virorum of the Italian.

Before leaving this great triumvirate of the most potent and golden period of Italian letters-a triumvirate which represents three steps, from the sublimity of poetic vision, through the higher experiences of the poetic real, down to unelevated or 
vulgar facts of the reality of prose; from a Beatrice through a Laura to a Fiammetta, who was very much flesh and blood; we must not forget to note their several vehicles of verse. Dante wrote in the terza rima, or stanza of three lines, linked in an arrangement which we may represent by $a b a, b c b, c d c$, and so on consistently. This is not found before him, though after him it became appropriated to Italian philosophic and satirical poetry. Petrarch's chief vehicle was the sonnet. Boccaccio composed his poems in the ottava rima, which he did not, indeed, invent, but which he fixed for ever after as the orthodox verse of Italian romance and epic, whether to be used by Ariosto and Tasso or by lesser men. The Italians are characteristically imitators of set forms, and the metres of Dante, Petrarch, and Boccaccio have bound their followers in a degree in which Englishmen have never been bound by any metres. When English writers adopted Boccaccio's ottava rima, they modified it. Chaucer dropped a line; Spenser added one. Yet both the stanza of Chaucer's Troilus and Cressida and the stanza of Spenser's Faerie Queene are none the less to be reckoned as borrowings from Italy, though both, we may believe, are improvements upon the original. That Spenser's, at least, was such is shown by the unanimity with which Thomson, Byron, Shelley and Keats accepted it for sustained works of their own.

The first three classics of Italy thus passed away. Boccaccio died in 1375 , and the Italian literature of Italy practically stood still. This was the age of the 
revival of learning, when the Latin and Greek classics, and at first particularly the Latin classics, were engaging the attention of every man who pretended to scholarship and taste, and when men of letters, instead of perfecting their own tongue and enriching it with works full of modern manners and modern thoughts, were engaged in a servile imitation of the ancient writers of Rome, especially Virgil, Ovid, Cicero, Plautus, and Seneca. It was a time of insatiate erudition in the things of antiquity, an age of great scholars like Bruno, Poggio Bracciolini, Filelfo, and Valla, but an age when all their best was written in Latin and that without originality or the savour of reality. It was also a great time of literary patronage. The princes themselves studied more or less earnestly, and affected literary taste, scholarship and Platonism. Scholars were in the highest repute, not only as teachers and companions of princes, but as ambassadors and counsellors. Every little state had its group of learned writers. The Popes at Rome, the Visconti at Milan; the Gonzaga at Mantua, the Este at Ferrara, the Medici at Florence, collected together men of letters and bestowed lavish gifts upon them. Cosmo de' Medici, the Florentine merchant who had gained the control of his city, turned his gardens into an academy. His trading agents collected manuscripts everywhere in Greece and the East. The first of those academies which afterwards became so numerous, and which bore such remarkable names as Della Crusca, Intronati, and the rest, began to spring up everywhere in Italy. Florence took the lead. The talk was of letters and literary taste. Much pedantry, 
no doubt, there was; but the universal love of letters was none the less genuine. Unfortunately it took the practical shape of a cultivation of writing in Latin, not in Italian. The illuminati of the day despised the tongue of Dante, Petrarch, and Boccaccio. They gathered and absorbed the ideas of pagan antiquity, but they did not yet seek to embody them in the language which men actually spoke. They learned the secrets of literary polish, but did not apply them to composition in Italian. So was it till towards the end of the fifteenth century, or, roughly speaking, a hundred years after the death of Boccaccio. These studies were anything but regrettable in the end: the immediate fault lay in exclusive devotion to them, to the neglect of the vernacular. When the fruits of classical study began to be utilized for the purpose of literature in Italian, the results were of the best. For the enthusiasm of the New Learning itself all Europe has reason to be grateful to Italy, and no country more so than England, from which (in I488) Linacre went to sit at the feet of Poliziano in Florence, whither also Grocyn and Latimer found their way.

At length, thanks to the efforts of Lorenzo the Magnificent, Poliziano and Pulci at Florence, and of Boiardo at Ferrara, there was a revival of Italian letters, a new breath of spontaneity passing over literary creation. There is no need to speak in detail of the sonnets and canzoni of Lorenzo de' Medici, modelled on Petrarch and addressed to a Lucrezia Donato as the counterpart of Laura, nor of the lyric grace and descriptive beauty of the learned and tasteful Poliziano. But of Pulci's romantic epic of 
Morgante Maggiore and Boiardo's Orlando Innamorato it is necessary to say a word, for the reason that they are the precursors of Ariosto's Orlando Furrioso, of Tasso's Jerusalem Delivered, and thence indirectly of Spenser's Faerie Queene. It is Ariosto and Tasso who rank next to Dante, Petrarch, and Boccaccio, and who consummate that sixteenth century or "Cinque Cento" literature which constitutes the silver epoch of Italian letters. Pulci's Morgante Maggiore and Boiardo's Orlando Innamorato are both " chivalrous romances," written in the ottava rima, or Italian equivalent of the Spenserian stanza. They are not exactly epics, but rather stories of knightly adventures, full of description and of the marvellous, of the romance of love and arms, full of knights who slay giants, liberate ladies, and fall in love with pagan maidens. Pulci's work, though often sufficiently earnest and stirring, is also often seasoned with that mocking humour, that irony, that refusal to take ideals seriously, which is one of the most constant of Italian characteristics. That of Boiardo is of a more serious type. These books, as has just been hinted, mark a revival of the wellknown French romances, of the adventures credited to the Paladins of Charlemagne. Such stories, which have no foundation in sober history, were early borrowed by the Italians, and everyone knew of Charlemagne, of Roland and Oliver, of the disaster of Roncesvalles, of the traitor Gano and the rest. It was for Pulci and Boiardo to take these legends of romance from the people, give them a literary shape, and so lead the way for the magnificent work of Ariosto. It may be mentioned in passing that Boiardo's 
Moorish hero Rodamonte, the insolent and atheistic - a name utilized by Ariosto in the form Rodomonte- has supplied a term for that species of bombastic romancing which we call "rodomontade." That Boiardo was read by Milton is clear from allusion in Paradise Regained.

In the next generation the Orlando Innamorato was recast by Berni into a mocking and satirical form, which was much more to the taste of the Italian mind. The language of this rifacimento is marked by greater ease and polish than the original, but its chief claim to distinction lies in the peculiar humour of the writer-the "Bernesque"-of interest to students of English literature, from the fact that Berni largely determined the character of the great productions of Byron's Italian period.

Italian literature has thus been brought back from scholars to the people, when Lodovico Ariosto begins to write at Ferrara. His works are various, including comedies and the inevitable sonnet after the manner of Petrarch; but it is the Orlando Furioso, the romance of "Orlando Mad," which renders him immortal. That work is of special interest here, inasmuch as it advanced English literature by inspiring the author of the Faerie Qucene with the clesire to "outgo" its power of perfect description, and its unending chain of marvels and adventures. The poem is a "romantic epic," begun in 1505 , and finished in eleven years. It undertakes-following Boiardo on a higher plane of art-to sing of Paladins at the court of Charlemagne, their loves, and their adventures, during the fabulous wars of that famous emperor with the Moors. The hero Orlando became 
mad through love of Angelica, and this madness, though it is only an episocle in the poem, gives the name to the whole. The entire work is full of the spirit of prowess, of marvellous adventures of heroes in rapid succession, their triumphs over the forces of nature and the spells of magic, and of magnificent descriptions painted by the poet as vividly as Italian artists painted with the brush-perhaps, it may be, somewhat too fully, too precisely. The actions are placed in an ideal world of chivalry, of knightly courtesy and knightly omnipotence, where there are no stubborn facts and limitations to interfere with the valour of the heroes. That world Ariosto did not create; he borrowed it from the French trouvères, and from his predecessor Boiardo, whose work he simply continues while throwing it into the shade. The magic and sorcery come largely from Arabian sources; nevertheless Ariosto himself is of imagination all compact, he invents episodes with wonderful fertility, and orders them with wonderful distinctness. And the style is of the most consummate in point of grace, elegance, and sweetness. He, like other Italians, draws character but faintly; he does not soar to great poetic heights, or descend to profound poetic depths; but in all the forty thousand lines of his poem, it is asserted by Italians who should be judges of their own tongue, that there is not one which is crude, inharmonious, or feeble. According to himself

Le donne, i cavalier, l'arme, gli amori,

Le cortesie, l'audaci imprese-io canto,

and it is not easy to see how such things could be more perfectly sung. 
Ariosto became a rage and a model. During the sixteenth century every Paladin and every Knight of the Round Table had his poet. Our own Spenser, deeply read as he was in Italian, had not only read Ariosto, but in all probability more than one imitator of Ariosto, and it is not for nothing that so many characters in the Faeric Queene, such as Archimago and Orgoglio, Duessa, and Fidissa, bear Italian names, names that so well fit the land of romance which the Italians had annexed for their own. In I 59I appeared the well-known translation by Sir John Harington.

Torquato Tasso, who lived during the latter half of the sixteenth century (1544-1595), and who also wrote at Ferrara, composed the world-famed epic Gerusalemme Liberata, or " Jerusalem Delivered." It is the epic or Iliad of the first great Crusade, in which Godfrey of Boulogne, who is the heroGoffredo indeed was the earlier name of the epictook back the sacred city of Jerusalem from the Saracens. It would be vain to attempt here to give an idea of this splendid heroic poem, of its vigour, of the beauty of language in its episodes, of the romantic experiences of the knightly Tancred and the heroine Clorinda, of the exploits, the miracles, the magic, and the enchanted forest. That it greatly influenced Spenser-whose Bower of Acrasia, for instance, is Tasso's garden of Armida - that it, along with the Iliad, the Aeneid, and the Divine Comedy, helped to build up the Paradise Lost of Milton, is one of its claims upon our special notice here. To Elizabethan readers the work was made accessible through the famous translation of Fairfax (1600), 
and by others of less renown. To Tasso also belongs an unfinished poem on the Creation, II Mondo Creato, with which Milton was manifestly well acquainted. Whether or not the English poet was also influenced in his Paradise Lost by another Italian production, the Adamo of Andreini, is uncertain.

Before proceeding further, we must take advantage of the mention of Tasso, and make reference to another form of composition, of which the Italians were always peculiarly fond, and which much affected the rest of Europe for nearly two centuries. We llave seen how the Greek Theocritus wrote idylls of country life in Sicily, and how Virgil composed pastoral eclogues on Italian soil. After the Renaissance-even the earlier wave of that name-the writers of Italy took up these themes and began to dwell again on country scenes, and on the delights of an ideal pastoral life, as far removed as possible from the vicious and troublous realities of their cities. Boccaccio, Poliziano, Sannazaro, Mantuanus are steps in the history of such pastoral before Tasso. The poet of Jerusalem. Delivered does not disdain this region of poetry. In his pastoral drama Aminta he places his highly cultivated and courtly shepherds, shepherdesses, and nymphs on the hills about Sorrento, and lends to their external life as much pretence at reality as he can command. But he is above all things a poet, and only secondarily a dramatist, and it is upon the lyrics that the chief effect is staked. What the great Tasso did, others must do, and at the end of the sixteenth century there are more than a dozen Italian verse-writers composing in similar strain. The chief is Guarini, with 
his Pastor Fido, destined to become well-known in an English shape as Fletcher's Faithful Shepherdess. But Tasso, as has just been said, was not the first to revive the pastoral. It was a century since Poliziano had written a Favola di Orfeo, a dramatic eclogue blending idyll and tragedy. But greatest among such predecessors had been the Neapolitan Sannazaro, who in 1504 had published the Arcadia, a medley of romance and eclogue, partly in prose, partly in verse, which gave its shape to our own Arcudia, the polished, if long and often tiresome, work of Sir Philip Sidney. Sannazaro indeed practically invented that mythical Arcady, or rural Utopia, into which poets and prose-writers have since made so many journeys in order to find a land where there still lingers the golden age of innocence and felicity amid bowers of beauty, where hard facts and bad weather never intrude. Another writer, Battista of Mantua-commonly called "the Mantuan"-composing in Latin, had also become a famous model in the pastoral kind for all western Europe. Readers of Love's Labour's Lost need hardly be told that "good old Mantuan" was a Latin school-book in Shakespeare's boyhood, and had also been imitated by Barclay, and translated by Turbervile. From him, partly direct and partly through the medium of the French Marot, came the cue for Spenser's Shepheard's Calender and its progeny. In the Elizabethan age, pastorals and pastoral plays were numerous, and among the writers must be reckoned Lyly, Lodge, Greene, Peele, and Giles Fletcher.

The work of Italy in this century-the "Cinque 
cento"- -was above all things work of artistic polish. The importance attached to beauty of style and elegance of words is apt to seem to us disproportionate. We are inclined to wish that the Italian writers had explored greater heights and depths of thinking and feeling, and had grappled more closely with matters of high seriousness. We find them enlarging, elaborating, and polishing tales of romance and adventure, or scenes of beauty and romantic life. We find them revelling in descriptions, and yet, all the time, ironically playing with the very unrealities of that which they describe, often plainly hinting to us not to take the matter too seriously. Above all things they are artists in style. And, therefore, it is natural to find that words are often compassed to the neglect of the matter. This was not only so in writing, it extended to their more courtly speech. It is largely from Italy, though partly from Spain, that there came over France and England that vice of affectation which developed a special shape in Euphuism. Before the appearance of Lyly's Euphues in I578, association with the gallants and wits of the Italian Courts had worked upon English pretenders to courtly graces. They deliberately affected forms of speech which should show both how much they knew, and how ingeniously refined they could be in novelty of phrase. Early Elizabethan literature is greatly tainted by Euphuism, with its tricks of language, alliterative, antithetical, hyperbolical, full of whimsical comparisons, overwrought descriptions, plays on words, avoiding natural forms of expression in favour of those which would "show off the writer's cultivation, his wit, and taste. 
Carried to its extreme in Italy, this minute attention to elaborate expression produced an irritating artificiality in the literature of the seventeenth century. The seicentisti produced many fine words, but little important substance. Literature declined into a plaything. Marini's affected figures of speech, farfetched comparisons, and tricks of verbiage, as illustrated particularly in his romantic Adone, characterized a generation of writers. "Marinism" in Italian literature, like "Alexandrianism" in the Greek, is now a term of reproach in letters. We cannot, indeed, in fairness, always attribute a mania of style to some definite inventor. Nor can we always draw clear distinction between one class of frigid, and finally exasperating, artifice and another. Unfortunately each new example is a new temptation, since exaggerations and tricks are always easier to imitate than the quiet and unaccentuated perfections of the consummate masters. The strained conceits of Donne and Crashaw, and in general of the "Fantastic" and "Metaphysical" school of our early seventeenth century, are one manifestation of the same spirit which was working in Italy. But Donne follows in the track of Euphuism, with new developments from his own talents, while others of the "Fantastics" go directly to the school of Marini. Among these must be included Crashaw, who both translates and imitates the Italian poet, and Cowley, whose early poems reproduce many of the Italian conceits.

In the seventeenth century Italian literature fell into its decline, and by about 1650 its influences on 
English writers ceased. Milton is perhaps the last great poet whose debts to Italian models and Italian culture can be declared measurable. His own knowledge of the Italian language, his travels in Italy, and his friendships with Italians kept him in touch with the current literature of the country. The sonnet was not dead in a land which was still to produce a Filicaia, and Milton was a sonneteer both in his own language and in Italian. His Comus is an Italian pastoral masque raised for once to the scope and dignity of literature, and to two famous poems he is led to attach the Italian names L'Allegro and Il Penseroso. What his great epic owes to his reading of Dante and Tasso is readily perceived, and the student of the two literatures cannot but feel that the quiet tone of noble sweetness in his earlier work is largely due, as it is with Spenser, to the fine example of Italy. We should, perhaps, add at this point that a less considerable contemporary of Milton, the artificial Cowley, was much under the influence of the Italian lyrist Chiabrera (1552-I637), whose sumptuous, courtly, gittering, but very un-Pindaric, "Pindarics" for a time challenged the lyric supremacy of Petrarch. It is not a little strange that Wordsworth also was so far attracted by Chiabrera as to translate certain of his poetical epitaphs. Nor is it to be passed over that Pope's heroi-comical Rape of the Lock was suggested-and in such compositions the suggestion counts for much-by the Rape of the Bucket (La Secchia Rapita) of Tassoni, who died in 1636.

It is hardly part of our subject to dwell upon Italian drama, inasmuch as it exerted but very little 
effect upon ours. So far as there was any, it was in the " masques," which owe their birth to the age of Poliziano, played no inconsiderable part in the court festivities of England from the time of Henry VIII, and came to engage so much of the learning and ingenuity of Ben Jonson. Yet masques are little more than glorified tableaux in glorified "private theatricals," accompanied by some form of libretto written ad hoc, and of almost no permanent value. Milton's Comus is no fair specimen of the class. It is, perhaps, scarcely relevant to literature to record that we owe our Harlequin and Pantaloon to the stock characters in the Italian semi-improvisations known as commedie dellarte.

Italians may think otherwise, but, to our foreign conception, Italy has never possessed a really fine dramatic masterpiece, tragic or comic. The drama of Italy, like drama elsewhere, had its prelude in the realistic presentations of religion, commonly known as " mysteries" and " miracles," but in Italy styled sacre rappresentasioni. But Italy, unlike France or England, quickly developed the purely secular drama from a source distinct from the Church. The Italians lay nearer to the Roman comedy, and it was in Italy that the Latin Renaissance came earliest. The ordinary Italian ingenuity and love of art and show produced the "masque," which was apt to be blent with pastoral, while the deliberate Latinizing of the cultured classes brought in imitations, often mere translations, of the comedies of Plautus and Terence, and of the tragedies of Seneca. In the development of its tragedy Italy became severely "classical," in the misused sense of the term. That 
is to say, it became Senecan, and obeyed the three unities. The vogue began with Trissino and his Sofonisba (1515), and was carried on by Rucellai, Alamanni, and others. Comedy, which also followed in the Roman path, was in a large degree emancipated by Aretino. To none of the dramatic forms, tragedy, comedy, drammipastorali, drammimusicali (opera, tragedia per musica), do we owe any real growths within our own literature. Late in the eighteenth century Alfieri did his best, within the Senecan conventions, to create a tragic stage, and much can be said in praise of his efforts and his talents; but he was no dramatic genius. Goldoni's comedies do not concern us. The one dramatic gift of Italy to Europe has been opera, which arose from musical pastoral in Rinnucini's Dafne. This, however, belongs rather to the domain of music. It is, no doubt, hard to pass by the lyric brilliancy and charm of Metastasio (who flourished about 1740), but for our subject he cannot fairly be regarded as of moment.

For prose, besides the novelle and novellini, we have in particular the much read and rightly detested Prince of Machiavelli, and the Cortegiano of Castiglione (1518), a book which speedily influenced English courtly ideals, both directly and through various manuals written in imitation. But there is little else to which conspicuous influence could be ascribed without exaggeration.

The "Novella" is regularly a short story outlined round a situation which is intended to be exciting. It is not a novel, but rather the sketch of one. In this domain Italy was exceedingly prolific. True 
to the national instinct for fidelity to patterns, the Italian novellieri are fond of the old device of Boccaccio, borrowed by Chaucer; they frequently pretend that their various stories are related by a company of persons accidentally brought together in a country house, or on a voyage, or the like, and placed in need of such mutual entertainment. The Pecorone of Ser Giovanni, the Hecatommithi of Cinthio, and the stories of Straparola, Da Porto, Bandello, and others, enjoyed a wide vogue in France and England, and formed matter for the exploitation of every class of our Elizabethan dramatists or writers of fiction.

* * * * * * * *

What English literature owes to that of Italy, except in the case of Byron's Bernesque period, it owes before the middle of the seventeenth century. From Dante to Tasso the obligations were great and manifold. To Italian stories, Italian sonnets and lyrics, to Italian epic, romance and pastoral, our writers from Chaucer to Milton are multifariously indebted. Most indebted of all is the great epoch which culminated in Shakespeare. Before his day the Tudor Court had much affected the language and courtesies of Italy. Italian travel was common, and Italians were relatively numerous in London. Even that sweet stateliness which characterizes so much of the Elizabethan lyric is a gift of Italy. To Italian skill and refinement of language, to Italian melodies of versification, our rough lyric beginnings owe debts more appreciable than to Italian matter. In other words, Italy taught us the art of writing, while leaving us to use it upon our own realities of thought 
and feeling. Before the poctical innovations of Wyatt and Surrey, English verse had stood in much need of further moulding of form and polish of language. It was an outcome of the partiality of the Court of Henry VIII for Italian art and manners that there arose the new school of poets whom Puttenham describes as "a new company of courtly makers, of whom Sir Thomas Wyatt, the elder, and Henry, Earl of Surrey, were the two chieftains, who, having travelled into Italy and there tasted the sweet and stately measures and style of the Italian poesy, as novices newly crept out of the schools of Dante, Ariosto, and Petrarch, they greatly polished our rude and homely manner of vulgar poesy from that it had been before, and for that cause may justly be said the first reformers of our English metre and style." Both Wyatt and Surrey are best known as sonneteers. Sometimes they are translating from Petrarch, but they are by no means mere translators, or even servile imitators. It is well known that the sonnet, as introduced by them, differs somewhat from the Italian, and its ending in an epigrammatic couplet is a purely English novelty. "Sonnet," indeed, was for a time used loosely for other forms than the true poem of fourteen lines; but, when it found itself, it had lost nothing in strength and beauty. Perhaps the chief impulse in establishing the sonnet in England, when a certain halt had occurred after Surrey, came from Watson's Passionate Century of Love ( ${ }^{5} \mathrm{~S} \mathrm{I}$ ), although in these "sonnets," Italian enough in spirit, the form is strangely made to consist of eighteen lines in three sestets. 
The whole Elizabethan world of lyrists "Petrarchized." The A moretti of Spenser made him to Gabriel Harvey "an English Petrarch," although in truth Petrarch is but one in a list of Spenser's models, which includes also Sannazaro, Ariosto, and Tasso. It would be easy to trace throughout the English sonneteers, from the appearance of Tottell's Miscellany in 1557 , the effects of many an Italian Petrarchist whose name has not been given in the foregoing sketch. Nor was the borrowing confined to the sonnet form or the sonnet spirit. It extended also to the "sonnet series" or "sonnet sequence." The notion of such related sonnets was introduced from Italy by Surrey in his series dedicated to "Geraldine," and from him was taken up by Sidney (to Stella), Spenser (to Rosalind), Constable (Diana), Daniel (Delia), Drayton (Idea), Lodge (Phillis), Giles Fletcher (Licia), as well as by Shakespeare, who, in his more noble way, leaves the object nameless. This development should perhaps serve as a warning to those who press Shakespeare's sonnets too rigorously for a key to his actual experiences.

Our servitude to France followed upon the decline of Italian influence. So far as we have been affected by Italy during the last century it has been due rather to the residence of English writers--Byron, Shelley, Landor, Leigh Hunt, Browning, Ruskinin the peninsula, than to any new fountains of inspiration to be found in its productions.

* * * * * * * * * * * * *

The English genius wisely rejected some portions 
of the literary offerings of Italy. Especially was this so in the domain of critical principle, and particularly as it concerned the drama. Sidney's Apologie for Poetrie follows the false doctrine of the dramatic unities as laid down by Castelvetro (1570), but such pseudo-classical plays as were attempted met with the fate which had previously attended Sackville's sterile effort of Gorboduc. The only useful and permanent contribution from dramatic sources was the blank verse of Trissino, which Surrey first borrowed for his translation of the Aeneid, whence it was passed on to the stage by Sackville. Taken up by playwrights, it was moulded into a powerful instrument by Marlowe, and thence grew to all its subsequent ripe uses. For the rest, when Gascoigne translated Ariosto's comedy I Suppositi in The Supposes, the Italian model itself proved barren, but the lesson of style in dialogue left its usual improving result.

In borrowing the Italian novelle and translating them, the English sixteenth century for a time reproduced their horrors and licentiousness, much to the disgust of many good citizens, who would scarcely have recognized themselves if described as Puritans. It became necessary even to order the burning of many of them for their wantonness. Yet on the whole the English selection, whether for mere reading (as in Painter's Palace of Pleasure), or for exploitation by the stage (as in Romeo and Juliet), or by prose fiction (as in the work of Greene), shows sufficient indication of the superior English sense of decency. Nevertheless, it was a recommendation to story-books if it could be said (truly or 
otherwise) that the tales came "from Italy." Nor did the borrowings of them cease till the Puritans closed the playhouses, for Massinger and Webster seek their situations where Shakespeare sought his, albeit their choice may be less sure.

* $\quad * \quad * \quad * \quad$ * * *

The Italians display literary characteristics not difficult to define. They are the heirs of the Latin tradition. But Latin literature, as has been stated earlier in this book, was not particularly original either in thought or style. It was not a highly imaginative or emotional literature; its verse tends chiefly to polish, and its prose to either declamation or epigram. It was marked by incessant strivings after verbal art, but not by any abandonments of passionate ardour, of lofty endeavours, or of profound meditations. It was a literature given to narration and satire; but not to exalted feeling. In other words, it was a literature of culture rather than of spontaneity. It was prone, therefore, to follow models, and to consider the form before the substance. In almost all these qualities Italian literature shares. Except in Dante, it hardly shows in any large measure the great poetic faculty of experiencing and vividly realizing great passions and far-reaching thoughts. Nearly all the Italians, after the vernacular had once been established, cultivate the most fastidious perfection of workmanship, while their thought and feeling are of but average depth, dealing with things positive and on the surface. Except in Dante and his age, Italian literature avoids the visionary and abstract, and deals by preference with the 
material and sensuous. It is not marked by potent and seminal thoughts, which are found almost only in Dante. For that reason it is Dante whom we generally satisfy ourselves with reading, if, indeed, we are not rather satisfied with talking of him and reading about him. 


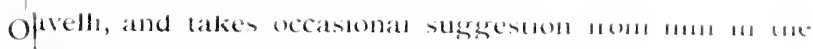
.

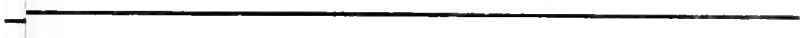


CONSPEC"TLS OF ITALIAN LITERATLRE

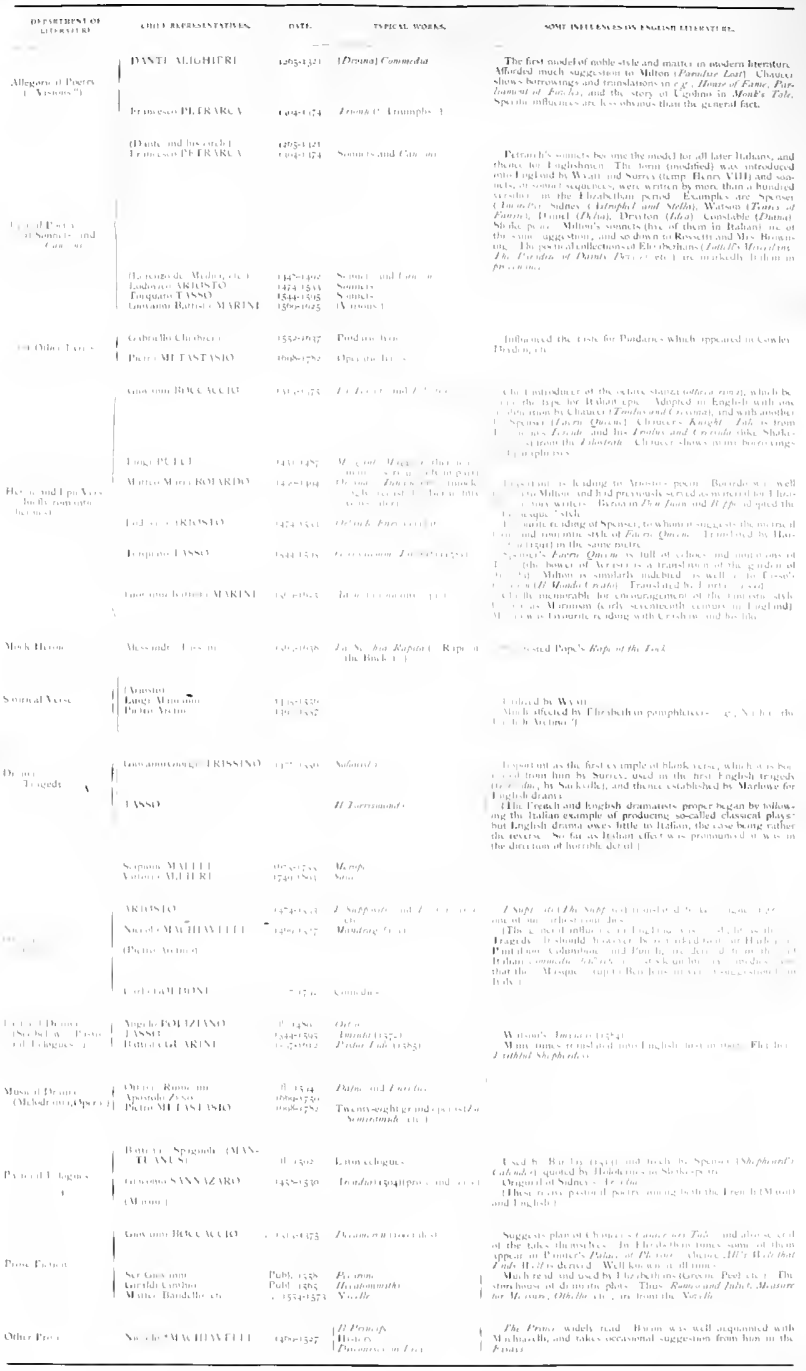




\section{OTHER LITERARY INFLUENCES SUMMARIZED}

\section{(a) Spanish Literature and English}

$7 \mathrm{HE}$ direct and avowed influence of Spain upon

1 English literature has hardly been comparable to that of France or Italy; nevertheless, in its totality, it has been sufficient to demand some concise review. Meanwhile that review necessitates, if less inevitably than in the case of Italy and France, an outline survey of the history of Spanish literature down to the middle of the seventeenth century. After that date the Peninsula, apart from its own lack of progress, cannot be said to count in our literary development.

In the summary of such literary forces as existed in the Dark Ages, we liave already spoken of the Moslem learning of Cordova, and of the agency of Moors, Arabs, and Jews in spreading science and philosophy. We must not forget also the influence of Arab lyrics accompanying Arab music, which not only operated in Spain, but also in Provence after the Counts of Barcelona had established their court in that region. The interpenetration of Christian and Moorish thought was, as a matter of course, continued for many generations during the Christian 
re-conquest, but from the eighth to the twelfth century both learning and literary art lay with the Moslem. When in the thirteenth century the dialect of Castile had become the most important, though by no means the only Spanish speech, it embodied but little contribution from the north. Such as it reveals is an imitation of the Carlovingian chansons de geste of France, in the shape of romantic poems of which the hero is Ruy Diaz de Bivar, commonly called the "Cid" (a corruption of the Arabic Seyd, "lord"). Side by side with these went the troubadour poetry common to the Provençal of Southern France and its closely related Catalonian of Eastern Spain. In the next and following centuries there were destined to spring from the Cid poems, combined with the Celtic tales of Arthur, brought through France from Wales, those romances of chivalry-libros de caballerias-of which something will be said in due course.

Meanwhile some noticeable elements in the character of the rising Spanish literature were being cultivated under Oriental influence. Chief among these were the love of aphorism and the love of story. The Spanish mind has at all times been peculiarly sententious, and the proverbial philosophy of Spain extraordinarily rich. The Spanish taste has also set strongly in the direction of fiction of no very probable kind, whether embodying more or less supernatural marvel, impossible sentiment, chivalric and pastoral, or crowd of incident. These predilections already showed themselves during the nascent period of the thirteenth and fourteenth centuries. The Spanish taste worked with the Oriental in respect both of proverb and story. The people of the Arabian 
Nights naturally passed on their répertoire more readily to their Spanish neighbours than elsewhere. The Arabic version of the Fables (or Tales) of Pilpay was translated under the same title of Kalila and Dimna, and the Arabic version of the Seven Sages (or Book of Sindabad) into the Stratagems of Women. $W$ ith these and other materials there went a native inventiveness, in which Spanish writers have seldom been deficient. When they proceed to issue stories in their own names, though still derived from eastern sources (as in the forty-nine tales of the Count Lucanor of Don Juan Manuel early in the fourteenth century), the sententious character common to Moors and Spaniards is in strong evidence. The same people which was gathering proverbial wisdom into such collections as Blooms of Philosophy and Mouthfuls of Gold, affected tales with a moral. Count Lucanor consists of stories, told by a minister to a prince according to the Oriental machinery, which are meant to do more than amuse. They have the credit of being the first collection of novels, if we may call them such, in modern Europe. Scattered fabliaux existed in France, and various tales were current in Italy, but there was as yet no Decameron. The extent to which portions of this early fiction filtered into England cannot very well be estimated, but in the neo-Latin countries, with their comparative nearness of language and traditions, their racial affinities and their common church, the tales enjoyed a large vogue, which brought them into the hands of the French composers of fabliaux, of Boccaccio's Italian predecessors, of Boccaccio himself, and thence of Chaucer. The plot of one of Don Manuel's stories 
is familiar to us through the Taming of the Shrew, and on the Continent some of them reappear in the dramas of Calderon, or the novels of Lesage. Nor was the circulation of the proverbs confined to Spain. In Caxton's Dictes and Sayings of the Philosophers, translated from the French, there appear aphorisms which correspond to those in the Spanish Florilegia.

The next step in Spanish literature consists of the prose "Chivalric Romances," or libros de caballerias, of which the existence is best known to the ordinary reader through the derision showered upon them by Cervantes in Don Quixote. The only exception which he makes is in the case of their parent, the original Amadis of Gaul (or Wales), as being the best book in this kind, and deserving of preservation as an example of a type. This Amadis, derived from Welsh sources, appeared early in the fourteenth century, but enjoyed its greatest popularity during the fifteenth. Elsewhere in western Europe the age of chivalry had already passed, but in Spain the spirit lingered. The Amadis romances, with their peculiar blend of Celtic knightly self-devotion and the semi-Oriental fondness for magical and other marvels, were entirely to the Spanish taste. About the original Amadis and some of its imitations, despite their extravagant conception of knightly honour and knightly prowess, and their lack of all reality of time, place, and circumstance, there is a certain tone or temper of nobility which redeems them from entire contempt. Beyond this the sequels to Amadis of Gaul, such as Palmerin, Palmerin of England, and Amadis of Greece, possess no literary virtues. They are simply more or less 
ingenious variations of one another, employing much the same figures and much the same situations. Their knights-errant are totally unreal, and move with much prolixity in an unreal world, of which the chief elements appear to be love and sorcery. Nevertheless, when reinforced by a new development, of which we are to speak next, their chivalric virtues gave them life under a new shape in France of the seventeenth century.

This new development was the pastoral romance. Our knights and their loves are now placed in the Arcady of shepherds and shepherdesses. It is the same world of chivalric impossibility of sentiment, heroism, and enchantment; but, during the vogue of the Amadises, Italy had developed the pastoral, and the increasing contact of Spain with Italysince the acquisition of Naples-speedily brought before the Spanish writers the example of Sannazaro. From the Arcadia of the Italian on the one hand, and from the libros de caballerias on the other, the Portuguese-Spaniard Montemayor created his famous Diana. This work, like Sidney's Arcadia, is partly in prose and partly in verse, and, in such English development as arose from the pastoral, the influence of the Spaniard must be reckoned with that of the Neapolitan. It appears in Spenser's Shepheard's Calender, and incidentally it may be observed that, before writing his Two Gentlemen of Verona, Shakespeare would seem at least to have been told of the substance of Montemayor. Not only did this influence come directly from the Spanish work, and from its translation into English at the end of the sixteenth century; it came also by way of 
France in the latter part of the seventeenth. For in France, early in that century, had appeared the Astrée of D'Urfé, based upon the Spaniard, and this in turn was the parent of those tedious creations of sentimental affectation, the heroic romances of $\mathrm{La}$ Calprenède and Scudéry, which have already been mentioned in dealing with the effect of French literature upon our post-Restoration writers of drama and fiction.

It would, however, be an error to suppose that, during this period of romance and pastoral, literature made no approach towards real existence. When war has come to play a smaller part in the national interest, and when reading is becoming general, a country which loves stories and "situations" will begin to find material for them in the facts, or at least the possibilities, of real life. It was so with Spain. In the latter part of the fifteenth century appears the first instalment of non-romantic or nonchivalric literature in the shape of Calisto and Meliboea, better known as Celestina, a work of uncertain authorship. A prose "comedy," though impracticable for the stage, and written in twenty-one so-called acts, it sets forth-ostensibly with a dissuasive moral purpose-a tale of intrigue and vice which might conceivably belong to the realities of contemporary Spain. "Realistic," indeed, it cannot be called, since realism describes things strictly as they are. The work was translated in all western Europe, including England. The fact that in the early sixteenth century the productions of Spain found ready access to our own country will be considered later. Mean- 
while it is most convenient to note the subsequent history of the Spanish novel of common life. That history was peculiar, but intelligible. Spain was growing weary of the monotonous pretences of the Amadises, and it was by the treatment of the most opposite type of humanity that the liveliest interest could be evoked. From the knight-errant to the rogue-errant was a grateful change. The country possessed a plenty of picaros or rogues, who lived by the exercise of their wits, and whose adventures might be embellished into stories at least as interesting as those of a Palmerin. The appearance of The Life of Lazarillo de Tormes, his Fortunes and $A d$ ventures (1554)-a work of unknown authorship, though commonly attributed to Mendoza-marks the date at which such stories first take shape as a distinct branch of the novel, to be known as the "picaroon" or "picaresque." From that time, for nearly a century, the "Novelas de Picaros" are a chief product of Spanish writing. In them the vagabond of low life is carried by his cunning and his luck through a multitude of such adventures as the Spanish mind considered humorous, even though they might not be particularly edifying. Unfortunately the hero and his history tend to become as stereotyped as those of the chivalric romance; and unhappily also many of the situations at which contemporary Spain could evidently laugh, are, to us, rather productive of pity or disgust. Chief among the progeny of Lazarillo are Guzman de Alfarache (1599), a sequel to Lazarillo itself by Luna (1620), and The Life of Buscon (otherwise entitled The Great Knave) by Quevedo (1626). All these were quickly 
translated into English. Upon England the effect of the picaresque novel first appears in the Jack Wilton of Nash, who was well acquainted with Spanish, and whose choice of a picaroon higher in the social scale than Lazarillo is merely a concession to contemporary English tastes and interests. In France the type passed through the hands of Scarron and reached those of Lesage, whose Diable Boiteux and Gil Blas were destined to eclipse the fame of the Spanish originals. From the example of France this species broke out in England with the Moll Flanders and Colonel Jack of Defoe, the Joseph Andrews of Fielding, the Roderick Random and Peregrine Pickle of Smollett. In the nineteenth century it finds its congeners in the Three Musketeers of Dumas and in the works of several minor English novelists. Mr. Jingle does not essentially differ from the type.

It is commonly said that it was the ridicule of Miguel Cervantes which destroyed the vogue of the chivalric romances. In reality he is rather the embodiment of his epoch, dealing the coup de grace to that which was already dying. His immortal Don Quixote appeared first in 1605 , when Amadis and Palmerin had already been losing their hold for a generation. Cervantes himself began with a pastoral Galatea, but it is not to be wondered at that his characteristic satirical sense of reality diverted him from this vein to the writing of original novels. Some twelve of these "Novelas Exemplares," or moral and instructive tales, were published in 1613 , and, though of uneven quality, they are the nearest approach which Spain could show to a novel of 
actuality. Some of these were soon converted into plots for dramas by the later Elizabethan playwrights. La Gitanilla becomes the Spanish Gipsy of Middleton, and Fletcher's The Fair Maid of the Inn is from the Illustrious Housemaid. But the abiding fame of Cervantes rests upon work of an entirely novel kind, and one which has remained unique, despite all efforts at imitation. Though full of contemporary Spain, Don Quixote is one of those immortal books which become the property of the world rather than of any particular country. Its happy conception and execution, its humour, its fine suggestion of the true gentleman, and its admirable style, combine to make Cervantes the one significant name in Spanish literature. Don Quixote, a poor gentleman of La Mancha, a true type of the Castilian with all his native dignity and ready acceptance of lofty views of honour and loyalty, has bemused himself-as so many others had done-with the reading of the libros de caballerias. Accepting the world of the chivalric romances as a real world, where wrongs and oppressions clamour for heroic knights to redress them, he saddles his gaunt mare, Rosinante, clothes himself in old armour, with a barber's dish for helmet, and sallies forth to seek adventures. To him Cervantes attaches the necessary squire in the shape of Sancho Panza, a goodnatured, ignorant peasant, endowed with a simple readiness to believe his betters, but also with a fund of vulgar shrewdness which forms an excellent contrast to the idealizing monomania of his master. The story consists of the adventures of this worthy pair. The inns which the knight takes for castles, and the 
windmills which he takes for giants, are now a commonplace, and had become proverbial in England within a few years of the appearance of the book. The word "Quixotic" itself tells the story of the vogue which the work secured. But thousands have been entertained by the book as a novel without realizing its deeper perfections. Don Quixote is something far greater than a satire upon the chivalric romances. It is a work of creative art, a perfect mirroring of two types of character, all the more true to nature for the apparent contradictions which each embraces. And Cervantes possesses the supreme gift of creation, in that, like Swift or Defoe, he makes his persons live. We are apt to feel, not that the Don is an imaginary character in a book, but that he once actually lived and entertained his noble delusions in La Mancha. The skill which not only saves him from contempt, but invests him with pathetic admiration, is in itself the skill of genius. It should be observed that Cervantes adapts his Spanish to the situations with the delicate tact of a master, and that more than usual is therefore inevitably lost in translation. The difficulty of imitating such a work is manifest. Among the best known must be reckoned the Hudibras of Samuel Butler (1663), but beyond adopting the notion of an errant knight and squire, in the persons of Sir Hudibras and Ralpho, he achieves little that is comparable to his original. Sir Hudibras is a cowardly and contemptible person of narrow mind, but, even as such, his treatment is inconsistent, and the verse which Butler employs in place of Cervantes' prose is but facile doggerel. It would be better 
indeed to speak of Hudibras as a vulgar, if often amusing, travesty of Don Quixote than as an imitation.

Meanwhile the Spanish lyric verse of the cancioneros, cultivated with much assiduity but with little genius, hardly concerns us, whether in its native form or when reshaped into sonnets and other varieties under Italian influence by "learned " poets like Boscan and Garcilaso de la Vega. Of most importance is the fact that poetry of the latter kind was disfigured by Gongora, a writer of the end of the sixteenth century, into one of those styles of exaggerated preciosity which always seem to secure a temporary success by their very absurdity. The estilo culto, otherwise known as Gongorism, was a deliberate invention, of which the main features were the consistent avoidance of the natural word and, as far as possible, of the natural order. Such tricks were congenial to the Spanish taste, which has always been too much inclined, whether in verse or prose, to verbose and ornate expression. Gongorism is but a new species of Spanish artificiality in this respect-a national characteristic recognized and ridiculed by Shakespeare in his Don Armado. How much of the peculiar style of Lyly's Euphues may be due to Spanish as well as Italian influences cannot be determined with any preciseness. But it should always be borne in mind that, after the marriage of Henry VIII with Catharine of Aragon, the English Court was frequented by Spaniards, and that, thanks to this fact, and the general prominence of Spain in the eyes of contemporary Europe, Spanish manners, 
whether of person or expression, were regarded as a proper subject of emulation by gallants and beaux esprits. This imitation extended far into the reign of Elizabeth. Before Gongora had introduced his new varieties of expression, this circle of Englishmen had been more or less familiar with the sententious antitheses and fantastic prolixities of the prose of Guevara (of the early sixteenth century), whose Golden Book of Marcus Aurelius and Golden Letters combined the characteristic proverbial philosophizing, often tediously platitudinarian, of his nation with its almost equally characteristic straining after uncommonness of phrase. Indeed it would seem that Elizabethan England caught from the Spaniards a taste for apophthegmatic wisdom which reached some among even the best of its writers, including no less a person than Bacon.

It only remains to remark briefly upon that form of literature which, apart from Cervantes, is the chief boast of Spain. This was the drama, established by Lope de Vega (I 562-I635), and polished by Calderon a generation later. Spanish plays had begun in the usual manner with the performance of "Mysteries" and "Miracles," of which the latter, when connected with the sacrament, were called autos. But from these Spain, like England, and unlike Italy or France, developed an entirely native species of drama. As in England, the attempts to impose the Senecan form, with its unities of place and time and its entire distinction of the tragic from the comic, entirely failed. But, unlike the drama of England, that of Lope de Vega and Calderon does not under- 
take to mirror human nature and action with all its various sides and complex motives. Its characters are but types, and, even as such, they are narrowly conceived. In the "cloak and sword" pieces a lady, a lover, a sober old man, and a clown, are the stock figures, who are brought into existence chiefly for the purpose of enacting their parts in certain ingenious and complicated intrigues with abundance of exciting or amusing situations. If Calderon shows a more finished style and a finer observation than Lope, his scope is otherwise the same. The Spanish stage does, indeed, like the French or Italian, affect frequent displays of rhetoric, but there the resemblance ends. Of special note among the comedias were those above mentioned as "cloak and sword" (de capa $y$ espada). The title refers to the usual equipment of a typical Spaniard of the higher middle class, who was the most natural hero of adventures and intrigues. It is not difficult to find in Ben Jonson and Fletcher resemblances to these plays of Spain. In France, where Spanish influence was at its highest in the time of Lope, comedy was inevitably affected by much that was congenial in the tastes and lives of the two peoples, and with the Restoration the same influence reached England in an attenuated form. Perhaps the most amazing thing in all Spanish literature is the miraculous fecundity of Lope, to whom are credited nearly two thousand plays, dashed off with a rapidity which remains a unique phenomenon. In finish they are, of course, to seek; but the passableness of the verse thus composed, and the ingenuity of the plots conceived, are beyond denial. To the Spaniards Lope 
was "the prodigy of nature," and "the Spanish phoenix."

It is needless for our purpose to follow further the story of Spanish literature, which, since the seventeenth century, has been singularly barren, and, in any case, has exerted no appreciable effect whatever upon our own. On the whole it has been justly said that the writing of Spain has not been quite worthy of the nation. Perhaps its best work, leaving Cervantes aside, has been in history, from which, however, we have derived no definite influence which can be classed as literary. Apart from these its merits are those of inventiveness in plot and of a certain high conception of dignity - a most consistent trait of the Spaniard. But it is a literature wordy in expression, lacking in insight, and seldom concerning itself with the deeper interests of human life. 


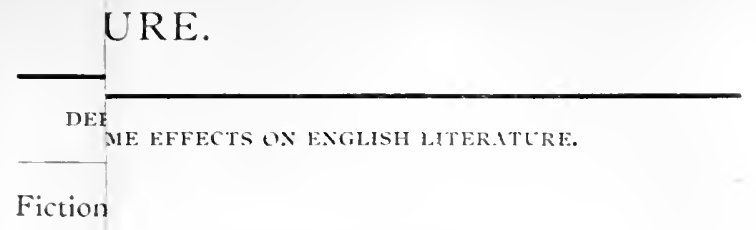

bck of fabliaux and noz'elle, and thence oceasion-

(a) Nor, ag., in Taming of the Shrea'.

ter Elizabethan playwrights, e.g., Middleton's ps.', Fletcher's Fair Waid of the Inn.

(b) C romances, combined with the pastoral, led "Lrfé) to the French "heroic romances" of La. and Scudéry. For their effect on English work, Literature.

(c) Pedia of Sidney and Spenser's Shepheart's Calender nfluence to IIontemayor. Diana was Englished of the sixteenth century.

(d) $\mathrm{F}$

source of the picaroon (or picaresque) novel, first Fgland in, e.g., Nash's Jack Wilton. In France ugh Scarron to Lesage. Taken up by Defoe(.1Moll tc.), Fielding (Joseth Andrea's), Smollett (Rotom, etc.). Revived by Dumas and his followers.

(e) $\mathrm{Sa}$

nd quoted in England at all times. Initated in adibres.

Poetry:

(a) $\mathrm{E}$ :

(b) Le

joins with Italian influence to create artificiallity

Ethical ton's Dictess and Say'ingss, ite.

Tudor England in encouraging apophehegmatic joun style.

and sword" dramas of situation and intrigute Drama fars of fonson and filditer. French comedy erial in lope, and lingland was llemec indirectly ir the Restoritiont. 
BRIEF CONSPECTUS OF SPANISH LITERATLRE.

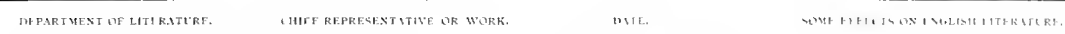

\section{Fiction}

(a) Vor.st Take:

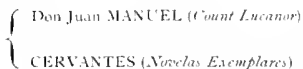

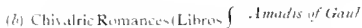
de $\{$ iaballerian

P Palmerin. Palme'rin of tengland, ede

(i) Pastorit Romance Ip.t IONFEMIYOR (Disma) prove, part verse) I CERTANTES(rialutet)...

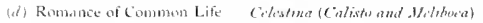

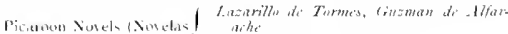
de picarios

( QLEVEDO(Lif af Buscon

le' S.turicil

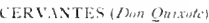

Peets:

(a) Eusly Romance

Pat'm in the rid

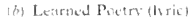

1 Ci.tRC'1L.th( ) IE L.t V'EG.

I GONGORt.

\section{Ethical Writim}

Dram.1 .

1 CALIERON

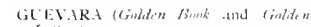
Litiors
E.toty fumteonth ientur?

$1 \mathrm{fi13}$

Furtecull comtur

Fincentl cellrurs

$1520-15^{t+2}$

$15 \sin$

Fiftecth actury

$153+1504$

atistis

$15+7-1016$

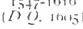

Tudfti and thir tectoth centuries

$$
15.30-150 \mathrm{~K}
$$

$15+1-1625$

$14+4-15 t^{6}$

$1502-1635$

itoot-1hisi

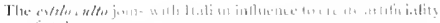
of $=11$ le:

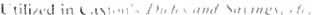

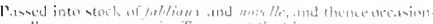

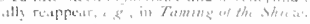

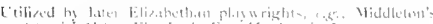

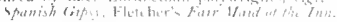

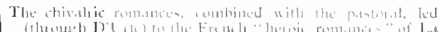

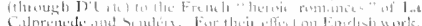

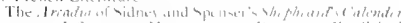

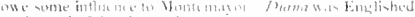

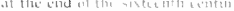

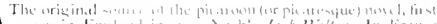

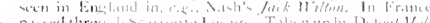

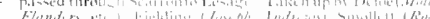

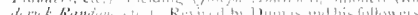

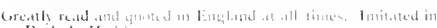

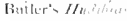

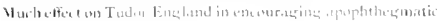

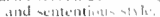

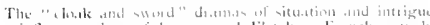

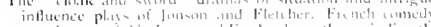

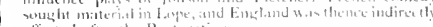
alfected alles the Ristorations.

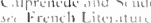




\section{(b) German Literature and English}

For our purpose, which is that of surveying the influence exerted by other literatures upon both the form and contents of our own, the writings of Germany are of less prominence than those of the countries with which we have hitherto dealt. To Latin our debt has been great and continuous; to Greek it has been less continuous, but essentially much more important; to Italian it was a debt of considerable dimensions for some three centuries; to French it has been an extensive obligation at two different and well marked epochs of some duration and potency. But to German we owed but an inconsiderable debt until the end of the eighteenth century or the beginning of the nineteenth, and, even since that time, the influence has been rather philosophical and scientific than literary-one affecting general currents of thought and methods of thinking rather than one affecting range of literary subject or manner of literary expression.

German "literature" at its best covers some halfcentury. The years from about 1770 to about 1820 were its golden period, the age of Lessing, Schiller, and Goethe. Since the latter date Heine alone stands forth as one of those names in pure literature which have a cosmopolitan, and not merely a German. significance. In speaking thus we are not forgetting minor poets like Uhland, or philosophers like Schopenhauer, or historians like Mommsen. But, in a literary inquiry of the present scope, we must 
not, on the one hand, confound science, even the science of philosophy, with literature; and, on the other, we must not lose our truth of perspective by magnifying the relatively small.

It is at first sight one of the most amazing facts in literary history that Germany should have been so late in arriving at a stage of creative genius which was reached five centuries earlier in Italy, a hundred and fifty years earlier in France, and nearly two hundred years earlier in England; for by so much time does the flourishing of Dante, of Corneille, and of Shakespeare, respectively precede the flourishing of Goethe. When we recognize what a capacity the German mind possesses for deep and sustained reflection, for tender sentiment, for rhythmic expression, we are struck with wonder that, before the days of Lessing in the latter half of the eighteenth century, German literature appears like a huge sandwaste, with here and there a poor oasis yielding for the most part but stony fruits and almost destitute of verdant beauty, except-and the exception is considerable-those simple and earnest Volkslieder in which the Teutonic feeling finds such touching outlet.

The Lay of the Nibelungen is properly an antique. The Minnesänger are to us little more than a tradition. Of the Meistersänger perhaps Hans Sachs is the only name which readily recalls itself. Luther we know full well, but, except for his hymn, Ein feste Burg ist unser Gott, he is remembered as a figure of theological controversy and a translator of the Bible rather than as a man of letters in the 
proper sense. We are familiar with the almost omniscient Leibnitz in the realms of science and philosophy; but it is not till towards the end of the eighteenth century, just before our own Wordsworth, Byron, and Shelley, that we meet with a fully matured and artistic literature, graced with numerous rememberable names-with Lessing, Goethe, Schiller, and, in a minor rank, Klopstock, Wieland, Bürger, Jean Paul Richter.

For this long sterility and slow development of German literature various reasons are assigned. We need not here pretend to estimate how far they are severally true. We cannot refer all literary outbursts to causes independent of genius. Nor is it necessary always to demand an extensive national life as a condition of literary fertility. Looking at the golden-age literatures of Athens and Florence, we should rather hold that it is a free-spirited and cultured life pervading a community, small or great, which stimulates to literary productiveness and excellence. It is, in fact, the prevailing ideals in a community which determine whether it shall create a splendid literature or not. In Germany there were for centuries no communities pervaded with this spirited and cultured life; the prevailing ideals were not in the direction. of any consummate artistic production. Till i 802 there existed, in name at least, as many as two hundred and fifty petty princedoms and paltry republics in Germany, for the most part little better than narrow feudal domains, struggling, ignoble, and selfish, as such disintegrated political atoms are wont to be. So long as these were really separate there was no 
grandeur of spirit, no high level of culture, in Germany. Nevertheless, for a generation before the end of the eighteenth century there had been growing up a wider and more national German sentiment and a considerable measure of union, political and social. It was not till this generation that Goethe and Schiller appeared. The wars which devastated Germany after the Reformation were of most hideous ferocity and unparalleled continuance, and had necessarily caused a dearth of literature as of other arts. What literature is to be found in Germany for two hundred years, from the time of our own Henry VIII down to the time of our George III-all those generations which include our Spenser, Bacon, Shakespeare, Jonson, Milton, Dryden, Pope, Gray-is almost entirely a literature of controversy, religion, hymns, criticism, and learning. Then at length, with the growing feeling of a general Germanic nationality and a general Germanic spirit and culture, with religious freedom established and controversy worn out, with the ideals of learning homogeneously spread, the time has come when literary genius finds its apt environment, and the thought and feeling of Germany take shape in dramas, ballads, lyrics, novels, and all other wonted forms. And then, for a generation, German literature is the dominant literature of Europe.

With the literary work-if we may call it suchof the monastic period, and with the religious poems of the learned German monks, we have nothing to do. German literature at all worthy of the name begins with the various Lieder, or romantic lays and 
lyrics of the twelfth century. The impulse to the Romances of Alexander and of the Table Round came from the trouvères of Northern France; the impulse to the lyrics of chivalrous minstrelsy came from the troubadours of Languedoc. During the Crusades the German barons were prominent, and that great motley pilgrimage of Frenchmen, Germans, Provençals, and Italians to the Holy Land was the means of spreading the legends and literary manners of the one to the knowledge and imitation of the rest. It was probably in this way, it was certainly at this time, that arose the Minne-Gesang and the army of Minnesänger, who were its poets. Minne means "love," and love is the special theme of those who copied the troubadours. The lyrics of the Minnesänger are primarily love-ditties of the kind which have been already described as current in Provence. Not that all their Lieder were lyric songs. There were also legends and romances, satires and fables.

Most famous among all the creations of mediaeval Germany stands forth the Nibelungen Lied, the "Lay of the Nibelungen." Properly speaking the title is The Calamity of the Nibelungen-Der Nibelungen Noth. The work is an epic, the one epic of Germany. It records how Siegfried, a hero of the fifth century, was done to treacherous death through the jealousy of the Amazon Queen Brünhild, and how his murder was ruthlessly avenged by his wife Kriemhild. The Nibelungen are properly fabulous giants of the Land of Fog, but when a vast treasure, which Siegfried has taken from them, comes into the hands of the Bungundians at Worms, these Burgundians become 
in turn the Nibelungen. And since it is upon the lords of these hapless Burgundian Nibelungen that Kriemhild's vengeance falls, the poem is rightly styled Der Nibelungen Noth. Such is the plot of this " Iliad of Germany," of which the collecting or formulation dates from about the year 1200, and which is full of great exploits and great passions, of witchcraft and murder and grimness. From a literary point of view the composition is one of great vigour but of no less great uncouthness.

One other product of the time deserves some mention. It is the beast story, or satirical fable, of Reineke Fuchs-" Reynard the Fox"-wherein the cunning of the fox is contrasted with the qualities of the other animals, who each bear a special sobriquet, and wherein human practices are all the time playfully satirized. That the French borrowed this beast-epic in their Roman de Renart from the Germans, and not the Germans from the French, is clear from the names borne by the various animals, such as the French renard, the fox, and baudet, the donkey, which are but the old German nicknames, Reynhart and Baldwin, in slight disguise.

Following the Minnesänger came the MeisterGesang and the Meistersänger. This was the age of trade guilds, when artisans met as in a club, and when each guild contained its poet or its poetaster. The shoemaker or weaver had often a fancy to be rhymester for his mates; thereupon were formed special guilds of poets of this sort, poetic artisans or artisan poets, and these were called the Schools of Meistersänger. Naturally enough the verse of men 
like these concerned itself, not with chivalry and troubadour lyrics, but with themes of common life, with wedding and christening songs, with songs of drink, of labour, and of domesticity.

In this age begin those special German Volkslieder, or "people's songs," of which some touchingly sweet and musical specimens are still read and heard today. The most prolific and best known of the Meistersänger is Hans Sachs, "the cobbler bard," who flourished about the year I 550 .

Of more importance to ourselves, perhaps, at this time was Sebastian Brandt. He is scarcely one of the Meistersänger, since he was no artisan, but a lawyer. Though of the same time and style he stands quite apart. Us he concerns because his work, the Narrenschiff, or "Ship of Fools," was imitated in the sixteenth century by our English Barclay, and was the parent of a considerable satirical progeny during that century. It suggested, for instance, both the conception and the title of such productions as the Ship of Drunkards. The "Ship" was chosen by Brandt to convey the fools he satirizes-fops, misers, drunkards, and the like-because no other conveyance was large enough. The captain was a bookfool, and his name was Sebastian Brandt. About I $55^{\circ}$ there was also translated by Copland, under the name of the Owol-glass, the famous Eulenspiegel, a series of amusing trickeries which are reflected in the English Robin Goodfellow.

The age of the Meistersänger is followed by the age of Luther, the Reformation, and the Thirty Years' IVar. It is an era of the founding of universities, of the spread of learning, of religious dispute carried 
on in pedantic language, an era when the popular speech was disregarded in favour of Latin or French. To speak broadly, there is no literature worth the name from the time of Luther, who died in 1546 , down to Lessing, who wrote in I 760. Nor is Luther himself a figure of literature proper. As a translator of the Bible into the Upper-Saxon dialect, and as having thus fixed the modern German language, he is of the greatest importance to Germany itself. To us his value is that of a thinker or moral force.

Yet there is one product of this long period which must count for something in virtue of its subject. It is the legend of Dr. Faustus, which was first printed in 1587 , was utilized by Marlowe for his most celebrated play, gave the hint for Green's Friar Bacon, and was revived by Goethe in his most famous and most influential work, the drama of Faust. It is reported that there actually was a person named Faust in Swabia in 1560 , who rejoiced in a reputation for sorcery, and in the companionship of the devil.

With a long leap over an irrelevant and wearisome interspace we arrive at the "Classic Period" of German literature. It seems better to call this the "classic" than the "classical" period, since the former word signifies the best and golden age, the age of the classic works, not the age in which literature followed the rules and canons of classicism after the manner of the French in the "classical" period of Louis XIV, or of the English in the "classical" period after the days of Dryden. It is a superlative merit of the great German writers that 
they, like our Elizabethans, and like our poets of the early nineteenth century, for the most part refused to be fettered by artificial rules.

Now was the time of a splendid crop of genius, a time when Frederick the Great had made North Germany more compact and peaceful, a time when princely patronage deigned to take note of literature. It was the time of a revolt against pedantry, of a reaction in favour of the national language, and of romantic and spontaneous literary creation.

The period of creation had been preceded in the early eighteenth century by a period of criticism, in which the German Swiss school of Bodmer, affecting the literary freedom of England, came into collision with the Leipzig school of Gottsched, which favoured the regulated literature of France. The latter faction, however, soon passed away, and Klopstock's Messias, inspired by Milton, though a work poor in action and character, showed how Germany was minded to abandon the mundane tone and interests which had satisfied the school of Voltaire and his Teutonic followers, and to adopt the cult of feeling and the ideal. For a time, it is true, the rising poet $\mathrm{W}$ ieland set himself in deliberate opposition to this cult, and proclaimed himself a pupil of the French; but, when settled at Weimar in 1772 , his French predilections did not prevent him from at least devoting his abilities to the reconstruction of old romance.

The attack on the old formalism and its rules, in favour of free and untrammelled genius, was deliberate and organized. It consisted on the one hand of the fresh and searching criticism of Lessing and Herder, and, on the other, of the efforts of German 
poetic youth. The name given to the young spirits of the literary revolt and regeneration, the clamourers for free play of spontaneity and imagination, was that of Stïrmer und Dränger. They were so called from the words Sturm und Drang, often translated "Storm and Stress," but in reality meaning "Vigorous Assault," which formed the title of a drama published by a certain Klinger in 1774 , although their appropriateness is not now easy to discern. This particular drama supplied, however, in its wild and extravagant structure, imagery and figures, a kind of manifesto of the new school. Those who sided with the movement were therefore called the "Storm-and-Stress men," just as the "Impressionists" in painting have been so named from the picture called Impressions, in which Monet first publicly exemplified their methods. Most of the poets who were afterwards to become famous belonged in their youth to this new school, went through its extravagances, and came out all the better for it in their maturity. Goethe with his juvenile drama of Götz, Schiller with his of The Robbers, had their "Sturm und Drang" stage, the stage when they allowed their imaginations and their language to run riot in wild extravagance.

The first great writer of the classic period in point of date is Lessing. He had nothing to do with the violent ardours of "Sturm und Drang." None the less he is a regenerator, a more powerful regenerator, and, in a sense, the founder of German literature. His dramas, with their central idea of depicting a hero whose character and conduct point a general moral, fixed the manner of German drama for Goethe 
and Schiller, and therefore for all German literature. His Minna von Barnhelm, and his Nathan the Wise, are moral lessons in military duty, or in religious toleration. They are the precursors and direct progenitors of Goethe's Faust and Schiller's Wallenstein. But, perhaps, of all Lessing's works that which is best known abroad, and which has been most powerful and far-reaching in its influence, is his Laocoon. Despite its errors and shortcomings, this famous treatise on the "Boundaries of Poetry and Painting," a work of criticism in the philosophy of the beautiful, has perhaps influenced more minds than any other work on aesthetics ever written except those of Aristotle and Longinus. To countless others besides Macaulay it has been their first illumination of the everlasting principles of beauty.

Side by side with Lessing, younger than he, but more ardent, went the Dichterbund, the "Poets' League," of Göttingen, whose object it was to make the poetry of Germans truly German, by composing natural lyrics and ballads of that sort in which modern German poetry perhaps abounds more richly, more musically, than any poetry of any other land. They, too, greatly influenced Goethe and Schiller, and from them Heine derives the impulse to his exquisite music and simplicity. Chief among them was Bürger, the ballad-writer and author of Lenore, who, perhaps, deserves additional mention as the reputed author of the famous adventures of Baron Münchhausen, perhaps the most perfectly ridiculous set of impossible lies ever invented.

To speak of Goethe, Schiller, and Heine, would require volumes. Perhaps nothing more perfect in 
their kind can be found than the lyrics of these three superlative artists, superlative in their simplicity of language, in their music, and in their clear-cut thought. Schiller's Song of the Bell is thought converted into, identified with, melody. Goethe's Heath Rose, his Serenade, his songs in Egmont; the gems scattered through Heine's Buch der Lieder; these show every possible virtue of poems in their kind. For what is the supreme merit of such a poem, unless that it should give expression to a worthy thought or emotion in exquisite language, which shall communicate it wholly, clearly, and movingly, by means of sounds and cadences acting like music on the emotions, and tuning the mind to a state of perfect receptiveness? This is precisely what the great German triad did, and, if German were only more closely regarded on its literary, as opposed to its utilitarian side, a study of German lyrics, odes, ballads, and songs might serve as the best of trainings for any who would learn to write them as poets should. Herein, perhaps, the literary influence of Germany has yet to work with ample scope and unmixed benefit.

But, though their lyrics alone are more than enough to make Goethe, Schiller, and Heine immortal, it is not by these that Goethe and Schiller are best known to the world outside of Germany. It is by dramas like Wallenstein and Wilhelm Tell that Schiller holds his place, while Goethe's fame is mostly identified with Faust, with Iphigenie, and with Egmont.

For German literature Goethe is the consummate name. He is the apex of the pyramid, and that in virtue of one sublime quality-originality, a word 
which perhaps means, after all, independence of observation combined with a keen capacity for its exercise. After passing through his Sturm-undDrangship, his morbid stage of The Sorrozes of Werther, and his intermediate stage of classical proportion, Goethe wrote as one who saw, and saw clearly. He saw facts, he dissected passions and motives. He could analyse the complex, and build up the elements again into a sound complexity. He has no narrowness. He displays a broad Hellenic tolerance, and a clear Hellenic way of seeing things in their reality. The influence of such a man must be vast. Byron and Shelley owned it and showed it. Carlyle, as stern a critic as ever played the pedagogue, is unmixed in his admiration for the man Goethe, who is to him divine. In his own country his Werther, despite its frequent morbidness and its longueurs, determined the feeling of every sentimentalist. Outside that country his Faust has become almost a textbook in poetical philosophy. He is translated, commented on, consulted like an oracle. In the reality and width of sway which he exercises, he stands next to Shakespeare among the poets.

"The genius of Germany," says Lamartine, " is deep and austere." The characteristics of German literature bear the impress of that national genius. The German mind is onewhich inquires and ponders. The German is, above all things, a deep and earnest thinker. Philosophy and learning, investigation in history, language, physical science, these belong to the Germans more than to any other people. We 
shall expect, therefore, to find German literature full of reflection and original thought, more concerned with the pursuit of the truth of that thought and reflection than with the form of expression. Heine, indeed, cannot be classed with the other great writers in this respect. Humour, wit, grace, music, all these he has in abundance. But he is apt to be reckless in his brilliancy; he is the incarnation of cleverness, but scarcely of sober and sincere thought. But Heine, though a German, was not a Teuton. He was a Jew. He wrote in German words in a German atmosphere, but hardly from a Teutonic mind.

Truth and earnestness are essentials of German writing. And therefore it is difficult to find in German literature mere writing for writing's sake. Its prose is the prose of discussion, argument, reflection, criticism, philosophy, analysis: its poetry is poetry of earnest meditation, real pathos, and real sentiment. Above all things German poetry is lyrical, and its lyric note rings true.

For German "literary" influence on ourselves we cannot point to much that is very definite. The influence of German philosophy in Leibnitz, Kant, Hegel, Schelling, Fichte, Schopenhauer, is one of thought in the scientific, not in the literary, aspect. We cannot say how great that philosophic influence has been. Nor are we under any obligation here to attempt the task. Neither are we concerned with the immense theological influence-which is also one of philosophy-that came to us from Luther. We are only concerned with the literary subject matter, 
the forms, and the principles which we may owe to Germany. Our conception of how history should be written owes much to Niebuhr, Ranke, and Mommsen; our aesthetic criticism to Lessing and Winckelmann; and our literary criticism to the brothers Schlegel. So long as there is intercommunication between countries by reading and by travel we necessarily expect ideas to pass in some shape and measure from one to the other. But it is only when great writers look abroad for formative influences that we can perceive and demonstrate a positive literary debt. English literature, and especially Shakespeare, has, in this respect, exercised much more influence on Germany than German literature upon ours.

In the sixteenth century we may find German legends like those concerning Bishop Hatto or the Piper of Hamelin transferred to England; we may find the story of Dr. Faustus producing Marlowe's Dr. Faustus and Greene's Friar Bacon; we may see Brandt's Narrenschiff translated as Barclay's Ship of Fools, and producing other satirical "Ships" of a similar kind. We may trace the thoughts of Pope's Essay on Man back through Bolingbroke's prose to the philosophic writings of Leibnitz. Yet instances like these are but scattered, and are intrinsically not of the first importance. A really large and steady influence begins for us with the end of the eighteenth and the commencement of the nineteenth century, with Lessing and Goethe in Germany, and thence with Coleridge, Byron, and Shelley in England. Coleridge and De Quincey were much read in German literature and philo- 


\section{6}

sophy; Byron and Goethe were mutual admirers; Shelley read Goethe along with the ancient classics; Scott practically commenced writing by translating Goethe's Götz into Goetz of the Iron Hand. Carlyle admired Goethe with an entirety which he refuses to any but the greatest; English thinkers and essayists are constantly quoting him. In our own day, when the knowledge of German is increasing, we all absorb more or less of the thought of Germany. Yet the influence is one of thought. It has not yet developed into an influence which can be seen to determine the form and tone of poetry or prose, as was the case with French and with Italian. The fact seems to be that German literature is naturally too much like our own to exert such clear and palpable effect. 
Kousseau, but itselt the source of "W Carlyle.

Philosop effect on Protestant thought in England.

on Man is derived, through Bolingbroke, from Leibnitz.

ssophy has dominated England since the age of who borrowed from Schelling), De Quincey, etc.

Criticism 
BRIEF CONSPECTLS OF GERMAN LITERATURE.

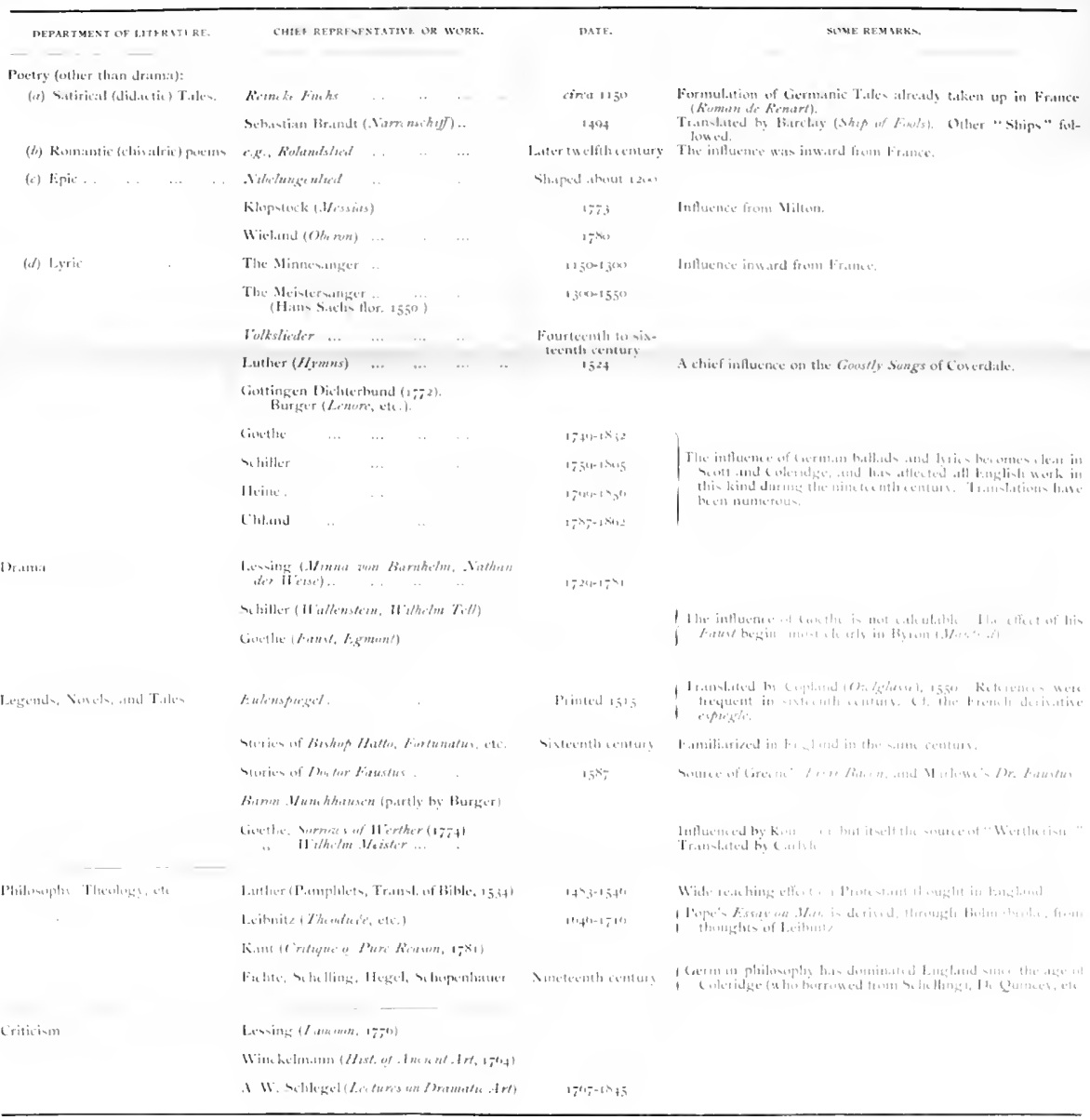




\section{(c) Celtic Literature and English}

WE are apt to forget how considerable a substratum of the "English" people is Celtic. The first historical inhabitants of Britain were mainly Celts. They filled England and Scotland as they now fill Wales; they still occupy most of Ireland and of the Caledonian Highlands. The conquering Romans with their settlers and legionaries affected the population very little. When the Anglo-Saxons and Danes came in their successive waves, and occupied the southern, eastern, and northern portions of Great Britain, they did not arrive in numbers so great as absolutely to sweep away the existing people, that blend of little Roman with much Celt. They simply laid thicker strata on the ethnological concretion. The Celtic strain was much thinned, particularly in England, but it was by no means eliminated. The subsequent Norman invaders count numerically for little in the mass. If, therefore, we take the whole body of English literature, and think of the men who have produced it in Great Britain and Ireland, we cannot but recognize that in those writers there were probably certain Celtic elements, which must have had some potency in determining their capacity for thought and feeling. Englishmen may call themselves Anglo-Saxons, and we may be mostly made of Anglo-Saxon clay, but we do not know how much of us is, after all, the contribution of a Celtic strain, with its characteristic tendencies, the melancholy sentiment and the chivalrous but inconstant 
ardour which mark the Celtic race. Nevertheless it is one matter to speak of the Celtic spirit in our literature, and another to display the influence of Celtic literature upon our own. Celtic literature properly means the literature of peoples speaking Celtic, and to that literature some debts are due, at least to the Cymry of Wales and Brittany.

Already before the Anglo-Saxon invasion there were doubtless floating among the British Celts legends of mystery and marvel congenial to the racial taste. After the conflicts with the Saxons a great chieftain, Arthur, grew into prominence, and around him were destined to gather both these older legends, and also new stories of adventures with human foes, with dragons, or with mysterious powers and spells. Christianity, working upon the natural temperament of the Celt, encouraged that idealizing self-dedication to the cause of love or piety, which belongs to knights with a mission to "right the wrong." It is this spirit which is the most important Celtic contribution to the literature of the middle ages.

In the sixth century Gildas, called by Gibbon the " British Jeremiah," who had at least been educated in Wales, writes in Latin his Destruction and Conquest of Britain, a dirge in the true tone of Celtic remonstrance against the hardshipof ruthless circumstance. In the ninth century Nennius composes a summary of Welsh traditions, in which we meet with the story of Brutus as the legendary colonizer of primitive Britain. In 1132 appeared the Latin His- 
tory of the Britons by Geoffrey of Monmouth, who pretends to base his interesting but unhistoric compilation upon materials gathered in Brittany by Walter of Oxford, but who probably collected at least as many from the neighbouring Celts of Wales. In this work are to be found not only the legendary Brutus, but also the stories of Gorboduc and Lear, afterwards to figure in Elizabethan drama. The cycle of Arthur is as yet incomplete; the Holy Grail is not mentioned nor the Round Table.

In I $_{55}$ the Jersey Norman, Robert Wace, converts and amplifies Geoffrey's work into the French romance Brut d'Engleterre or Geste des Bretons, introducing for the first time the Table Round. This again is developed in English verse by Layamon in his Brut of 1205. From various sources, and by various hands, the Arthurian legends are increased, first in the romances in verse, next in the romances in prose. Though the infusion of Celtic chivalrous sentiment appears in all, there are naturally various degrees in the mysticism and asceticism which they display. The vogue of these romances was not confined to France and England. As with other portions of the epic verse of $F$ rance, it passed into Italy, and inspired both the predecessors of Ariosto and also that great poet himself. Thence, as well as from the sources nearer home, it awoke the interest of Spenser. To the same subjects Milton also was for awhile strongly attracted. In his Epitaphizm $D a$ monis he shows the hold which the Arthurian legends had taken upon him, and he explicitly proposes to make Arthur and the British knights the subject of an cpic. In the Sabrina of the Comus, and in various 
references, the same poet reveals how well read he was in the matter of Geoffrey.

In Spain "matter of Britain" took a new lease of life. In that country was produced the series of clivalric romances in prose, which began soon after the year 300 with the Amadis of Gaul (i.e., Wales), and continued for nearly three centuries, until, from their increasing extravagance, they fell into disrepute, and were finally slain by the satire of Cervantes. How these operated together with pastoral, to produce the sentimental longueurs of La Calprenède and Scudéry in France of the seventeenth century, and thence affected the novel and drama of post-Restoration England, is told in the sketch of the literature of Spain. The affiliation to Celtic origins is in this case clear enough, but with the circuitous route there goes a gradual defection in that real Celtic spirit which was possessed by the original Amadis.

When we are asked at what date English literature is most distinctly affected by the creations of Celtic countries, we may reply that it is chiefly before the age of Chaucer, when the romantic legends of Arthur and his Table came through two channels; on the one hand through Breton sources, on the other through Wales. This is, in point of subject matter, the largest Celtic contribution on which we can lay our hand. To it we owe not only the Arthurian cycle of romances as we find them in Geoffrey, the trouvères, Layamon, and later in the compilation of Sir Thomas Malory (called Morte D'Arthur), which was one of the earliest books that Caxton chose to print; but also much reference in Spenser and Mil- 
ton, as well as the whole substance of Tennyson's Idylls of the King. To a once independent group of legends, afterwards brought into relation with the Arthurian, we owe the exquisite Tristram and Iseult of Matthew Arnold.

It was in "matter of Britain" that appeared the special vein of tender chivalry which passed into the romances, first of France, then of Italy and Spain. Not in Germany, not in Italy, not in Provence, not in Spain, did these stories of knightly loyalty and uttermost honour and devotion take their rise. It was in Northern France, where Franks and Normans were in contact with the large Celtic remnants of the Bretons. In all these legends there speaks the Celtic voice, rememberable and distinguishable everywhere by its prevailing melancholy, its devotion to a cause, be that cause right or wrong, be it strong or weak.

For the rest, we are in no position to fix the first invention of the Quest of the Holy Grail, or any other legend of the cycle, upon any definite author. What we allow to Tennyson in his liberties with the details of the stories and the form they take, we must perforce allow to the many who had told and retold the same stories scores of times since the Celt of Britain first passed them on to Brittany.

A very dubious, if not wholly mythical, figure in Celtic literature, is the once hugely admired Ossian. Macpherson, a contemporary of Dr. Johnson, came into prominence at the time when the eighteenth century was growing weary of the "classicism" of the school of Pope, and was ready to be interested in the simple, frank, romantic world. Macpherson was 
a Scotsman, who pretended to have collected from manuscripts, and from the memory of Highlanders, sundry poems of a certain Ossian, a Gaelic poet of the third century. These he translated into pompous declamatory prose, attempting something like the style and imagery of the Hebraic scriptures, but overstraining both. They were received with $\mathrm{im}$ mense enthusiasm in England, France, and Germany, and were Napoleon's favourite odes. Unhappily the alleged originals will, for the most part, not bear the light of criticism. Johnson did not scruple to call Macpherson an impostor. That there was an Ossian is probable, but the few poems which can with tolerable safety be assigned to him belong to a much later date than Macpherson claimed. Nevertheless, though Macpherson's Ossian may be as great an imposture as Chatterton's Rowley Poems, he, no doubt, did gather from the Celtic fragments and the Celtic folklore a mass of imagery and fire of words, which came in most fitting time to lend some help in ridding the weary world of the stereotyped coldnesses of the followers of Pope. 

SOME POINTS IN THE PEDIGREE OF POETRY.

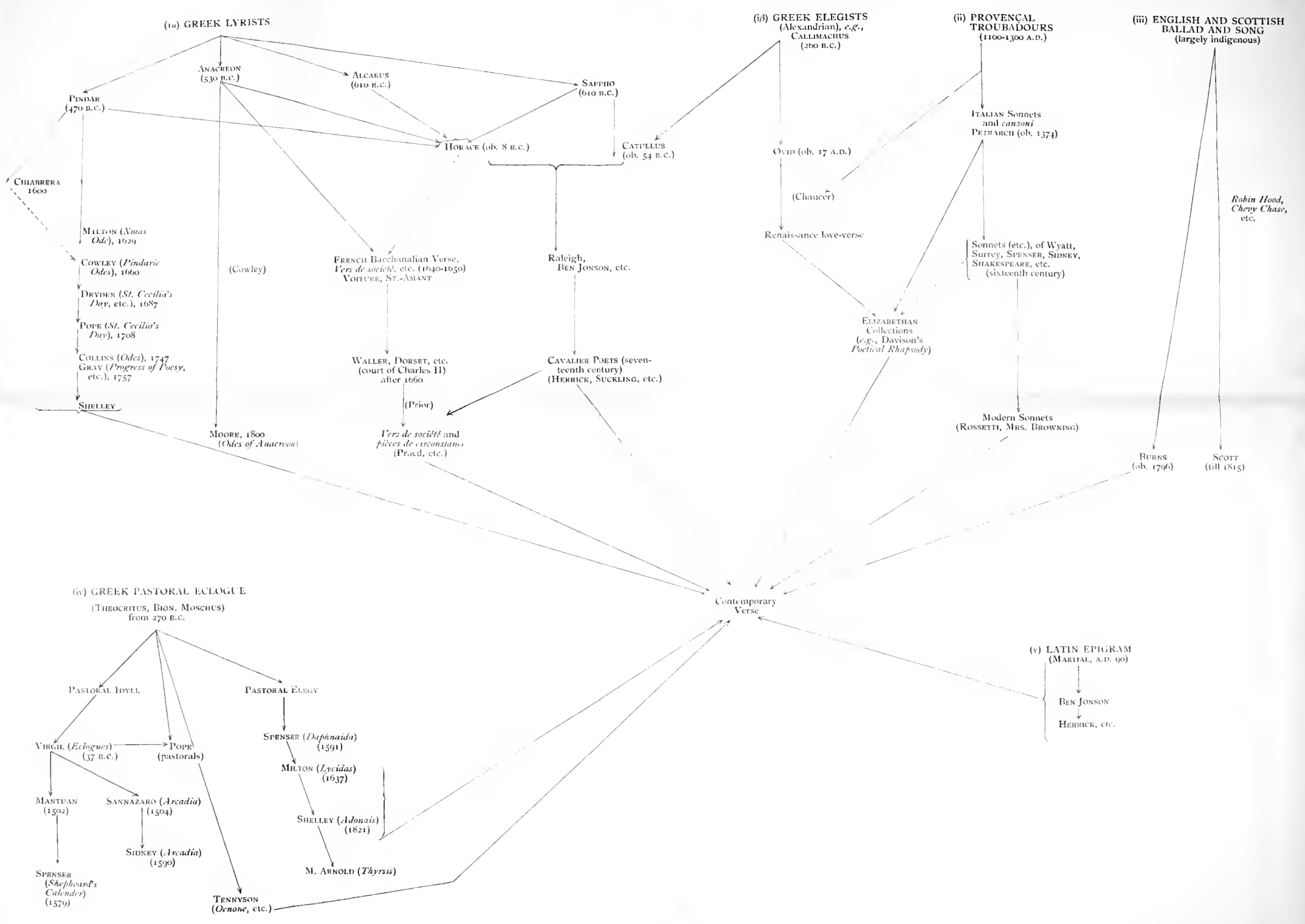




\section{(d) Hebrew Influence}

For those who are not Hebrews, Hebrew literature means the Bible, and especially the old Testament of that Bible. It would be a vain pretence to attempt to show precisely how far the Bible has influenced the thought of English writers. It is not our province here to deal with morals and moral influence, however much we may recognize that, since out of the fullness of the heart the mouth speaketh, our English literature could not have been the literature it is, if the moral disposition and attitude at the back of it had been other than they are. And these have been in the largest measure determined by the Old Testament of the Hebrews.

Imagine for a moment that the Bible did not exist, that no Englishman had ever read one line of it, that the religious notions which it inculcates were without expression in any such established standard. Our way of looking at life and at things suprasensual, our maxims of conduct, our ideals of fecling, would obviously be something widely unlike those which we now entertain. A nation's literature is the expression of a nation's soul. Give us a different soul, and the expression will convey that difference. We cannot separate literature from moral conceptions and moral tone, and therefore, in a sense, the Hebrews have determined our literature more than all other influences combined. And there is this manifest and vastly important difference between the influence of the Bible and the influence of any other work. The Biblical thoughts have be- 
come part of our earliest, youngest, and most plastic selves. We are born into them, and brought up in them, as something natural to ourselves. The English heart and mind are now partly made of Hebrew thoughts and ideals. This fact is so obvious that we need not pursue it further. To other literatures we have looked for models to imitate and notions to borrow; to the Biblical literature we have looked for a transfusion of all our thinking.

But there is also a purely literary effect of the Bible, concerning which a few words must be said. Who can estimate the immense extent to which Biblical imagery and Biblical phrase-what one may call Biblical styleand Hebrew style-have determined the style of English writers? Remember that the average English child is brought up on the Bible, that he reads, marks, learns, and inwardly digests it; that its diction and its figures of speech persist, however loosely, in his memory. What is the result? Is it not that, though in a less degree than with the Puritans, there remains, consciously or unconsciously, a habit of imitating those figures and further developing them; of imitating that diction, and carrying it into his higher forms of speech and his writings? Take the great preachers and religious prose writers from Jeremy Taylor to Cardinal Newman, and observe how their language unconsciously follows the rhythm, clothes itself in the dignity, and repeats the very phraseology, of the authorized version of the scriptures. Take poets like Milton, or mere verse-writers like Akenside, and see how their language seems to echo the language of the Testaments, Old and New. 
It is true that the language of the "Authorized Version" is English and not Hebrew. None the less the imagery, the similes and metaphors, the fiery turns of exhortation and denunciation, the fervent question and the apostrophe, all these and other elements which make up style, are, apart from the rhythm, Hebrew and not English. And it is to these things we refer when we speak of the purely "literary" effect of the Bible on our writers. Quite apart from the spiritual effect which is sought for without reference to the qualities of the style, there are, all the time, powerful qualities in the Hebraic style itself, qualities often reaching to the poetical sublime. Take, for instance, the passage, "Whither shall I go then from Thy Spirit, or whither shall I go then from Thy Presence? If I climb up into heaven, Thou art there: if I go down to hell, Thou art there also. If I take the wings of the morning and remain in the uttermost parts of the sea, even there also shall Thy hand lead me, and Thy right hand shall hold me. If I say 'Peradventure the darkness shall cover me,' then shall my night be turned to day. Yea, the darkness is no darkness with Thee: but the night is clear as the day: the darkness and the light to Thee are both alike." And once again: "Ye mountains of Gilboa, let there be no dew, neither rain upon you, nor fields of offerings: for there the shield of the mighty is vilely cast away, the shield of Saul, as though not anointed with oil. From the blood of the slain, from the fat of the mighty, the bow of Jonathan turned not back, and the sword of Saul returned not empty. Saul and Jonathan were lovely and pleasant 
in their lives, and in their deaths they were not divided. They were swifter than eagles, they were stronger than lions. Ye daughters of Israel, weep over Saul, who clothed you in scarlet, with other delights; who put on ornaments of gold on your apparel. How are the mighty fallen in the midst of the battle!"

What we are here concerned with is the way in which the diction of every English writer has been dominated from his youth up by echoes of words like these, which he received in to his plastic mind in childhood, and which mix themselves with his thoughts as he shapes the words and the images of his English prose or verse.

If, indeed, we were to take our greater authors and read them through, pencil in hand; if we were to mark those words and images and turns of expression which we feel to be derived consciously or unconsciously from the English version of the Hebrew Bible, we should be amazed to find how much of purely literary strength and dignity that one book has added to our tongue.

And this Hebrew influence has existed ever since we were a nation, nay, even before. There was, indeed, no translated English Bible till the days of Wyclif, the contemporary of Chaucer; nevertheless the images and thoughts of the Latin Vulgate had become part of every good ecclesiastic, and in all preaching and exhortation the Biblical phrases were heard in English, perhaps rougher and less rhythmical than those of ourown version, butstill with their essential quality retained. Remember again that, still in these days, in all Christian churches, 
the language employed is deliberately Biblical, that the prayers are Biblical in expression, and that the language is considered the more apt and more effective in proportion as it more distinctly bears the Hebraic impress. Put all these considerations together, and it will be recognized without need of further words than on literary style, as well as on moral sentiment, the influence of the one Hebrew book has been unparalleled. Meanwhile the writings in English verse and prose which have taken their titles, their subject matter, their suggestions, or their inspiration, from the Bible, would form an interminable list. 

(iv) IrIstutle

(Ethics)

$$
\text { ing. } \quad 1 *=\text { close }
$$


SOME POINTS IN THE PEDIGREE OF EPIC VERSE

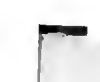

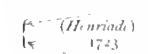

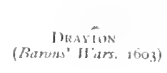

(iii) TuE BrbLF

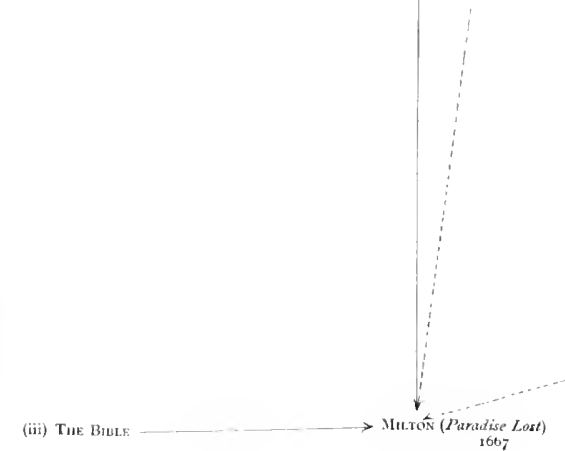

VIRGIL (Amerid)

t: : $8 . \mathrm{C}$

LUCAN (Pharalian)

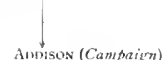

DANTE (132)
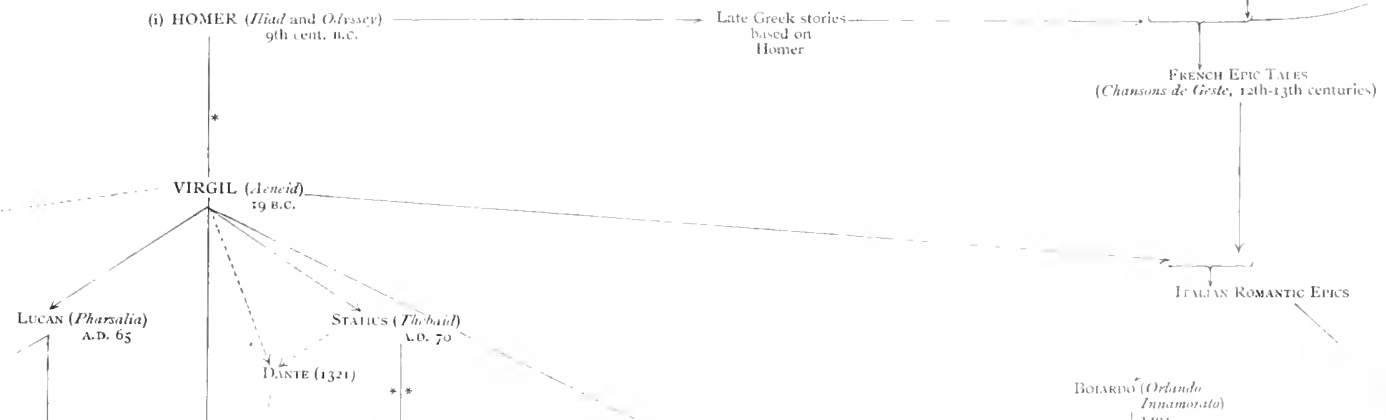

Bucatcho (Te seide)

ob.

$*$

Chater (Finight's Talc)

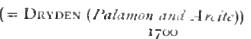

* = close imitation. (ii) OlJ French rhysmes of

+ Cellic legends of trothur and Table Round

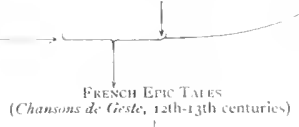

BNAYSOE (Idvlls ef the King, etc.)

Javol (Tristram and Isrult, etce)
SPENSER (Fiacric Quecenc)

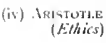




\section{INDEX OF AUTHORS AND IVORKS}

Achilles Tatius; Leucippe and Cleitophon, 132.

Addison, Joseph, $f^{2}, 43,113$, I 4 , I74, 177; The Campaign, I12; Cato, 79, 112, 170; the Spectator, 138, 173.

Aelian, 133.

Aeschylus, 19, 21, 49, 59, 62, 72; Agamemnon, 22, 66; Eumentides, 20; Persae, 62; Prometheus Bound, 21, 62, 65.

Aesop, 33, 34, 94, 95, 129, 134 . Akenside, Mark, 25+; Pleasures of the Imagination, $\mathrm{I}_{3} 3$.

Alamanni, Luigi, 2 ro.

Alcaeus, 16, 54, 107.

Alciphron, 35 .

Alembert, Jean d', 176 .

Alfieri, Count, 2 ro.

Alfred, King, 95, Ix 3; translation of Boethius, 118 ; translation of Aesop, 135.

Amadis of Gaul, 220, 250.

Amadis of Greece, 220.

Ambrose, St., II 7 .

Ammianus, 117 .

Amyot, Jacques, translation of Plutarch, 161 .

Anacreon, $17,46,69$.

Andreini, Giovanni Battista; Adamo, 204.
Andronicus, 78 .

Apollonius, 67.

Apollonius of Tyre, 132.

Apuleius; The Golden -1ss, 110 ,

$12 \mathrm{I}$.

Arabian Nights, the, 129, 219.

Archilochus of Paros, $15,4^{\text {b. }}$

Aretino, Pietro, 95, 210.

Ariosto, Lodorico, 93, 179,196 , 197, 212, 21 3, 249; I Suppositi, 2If; Orlando Furioso, 200203 .

Aristophanes, 24, 17o; Birts, $24,25$.

Aristophanes of Byzantium, 35.

Aristotle, 30, 31, 39, $77,48,57$, $58,91,129,130,166,241$; Poetics, 35, 57; Rhetoric, 35. Arnold, Matthew, fo, $+1,+4,57$, 159, 177; Essuys in Criticism, $8_{3}$; Thyrsis, 26, 56, 6S; Tristram and Iseult, 251; Works showing Greek influence, 67, 68.

Aroutet, François Marie. S'é Voltaire.

Athenatus; Dripnoseph ists, 35 . lugustine, Saint, 71; Citp of liod, 32, 117.

Ausonius, $71,117$. 
Averrhoes; translation of Aristotle into Arabic, 48,130 .

Avianus, 34 .

Babrius, 34, 134 .

Bacon, Lord, 33, 50, 111 , II3 I62; Essays, 234; New Atlantis, 32 .

Bandello, Matteo, I95, $21 \mathrm{I}$.

Barclay, Alexander; Ship of Foóls, 237, 245.

Barclay, John, 205.

Baron Mïnchliausen, 241.

Bartas, Guillaume de Salluste du; Semaine, I57.

"Basoche, La," I65.

Battista of Mantua, 89 , 204, 205.

Battle of the Frogs and Mice, 60.

Bede; Ecclesiastical History, I 22.

Behn, Mrs. Aphra, 173.

Bellay, Joachim du, $15^{6},{ }_{157}$, 192.

Benoit de Sainte-More, I34, I42; Roman de Troie, 150.

Beoz'ulf, 125.

Béranger, Pierre Jean de, 175 .

Berkeley, George, 3 I.

Berni, Francesco, 201.

Bible, the, 117, 123, 124, 253257.

Bidpai. See Pilpay.

Bion 6, 25, 56, 69 .

Blooms of Philosophy, 219 .

Boccaccio, 48, 49, 85, I33, 135, 149, 179, 199; Decameron, 194I97, 2II, 219; other works, 196.
Bodmer, Johann Jakob, 239.

Boethius, 7I, I17, I21, 122; De Consolatione, $\mathrm{x}$ I8.

Boiardo, Matteo, 199; Orlando Innamorato, 200, 201, 202.

Boileau-Despréaux, Nicholas, I09, $139,158,159,160,163$, I7o; Art Poétique, 6, 90, 159. Bolingbroke, Viscount, 245 .

Book of Sinbad, the, 195.

Boscan, Almogaver, 227.

Bossu, René Le, r7o,

Bossuet, Jacques Bénigne, Iof.

Bracciolini, Poggio, 198.

Brandt, Sebastian; Narrenschiff, 237,245 .

Browning, Elizabeth Barrett, 192.

Browning, Robert, 4I, 44, 88, $2 x_{3}$; translations from the Greek, 22, 66.

Bruno, Giordano, 198 :

Bürger, Gottfried August, 233, 24I; Lenore, 24 I.

Burlee, Edmund, rof.

Burns, Robert, I5, I6, 86, I I5, $137,138,154$.

Butler, Samuel, 97 ; Hudibras, 226, 227.

Byron, Lord, 22, 43, 65, 175 , I 76, 197, 211, 213, 233, 243, 245, 246; English Bards and Scotch Reviezvers, 97 ; Manfred, 65 .

Caesar, 75, 80, 90, 99, 108; Commentaries, 100.

Calderon de la Barca, Pedro, I66, 220, 228, 229. 
Calisto and Meleboia, or Ce'lestina, 222.

Callimachus, 68,87 .

Callisthenes, 133, 134 .

Calpurnius, 89 .

Calverley, C. S.; translation of Theocritus, 27 .

Capella, Martianus, I2I, I 22.

Carlyle, Thomas, 99, roo, гог, 243.

Cassiodorus, 122.

Castelvetro, $2 I_{4}$.

Castiglione; Cortegiano, 210.

Cato; On Agriculture, 98.

Catullus, $73,75,80,85,86,87$, I08, II2, II4.

Cavalcanti, Guido, 189.

Caxton, 250; Esope, 135 ; Dictes and Sayings of the Philosophers, 220.

Celsus, 98 .

Cento Nor'elle, the, 195.

Cervantes, Miguel de, 224-227, 228, 230; Don Quixote, 220, 224-227; Galatea, 224; Noi'elas Exemplares, 224, 225.

Chapman, George; translation of Homer, 13, 52, 60, 64.

Chateaubriand, Vicomte de, $175,176,177$.

Chatterton, Thomas; Rozeley Poems, 252.

Chaucer, Geoffrey, 39, 40, 4I, $43,44,46,47,94,99,113,118$, $134,135,136,137,138,141$, $148,153,177,179,182,192$, 197, 21 1, 219, 256; Canterbury Tales, 85 , I1 1 149, 195, 196;
Court of Low', I45; Romannt of the Rose, 163 .

Cheke, Sir John, 49, 57.

Chénier, André, 174.

Chestertield, Earl of, $173,177$.

Chiabrera, Gabriello, 208.

Cibber, Colley; The Von-/uror, I $7 \mathrm{I}$.

Cicero, $72,75,80,102-106,107$, $112,114,116,121,198 ; D$. Orature, ro2; moral treatises, 102; orations, ro4; letters, 105, 106, 108, 113,173 .

Cino da Pistoia, I 89.

Cinthio; Hecatommithi, 195, 2 II.

Claudian, 7I, II7, I 22.

Coleridge, S. T., 44, 245 .

Collins, Willian, 54 .

Colonna, Guido; History of the Trojan War, I34.

Columella, $9^{8}$.

Comines, Philippe de, I61.

Comte, Isidore, I77.

Congreve, William, $54,78, \mathbf{1}_{3} 8$, 177 .

Constable, Henry; Diana, 213. Copland; the Owl-glass, 237 .

Corneille, Pierre, 22, 79, I39, $158,166,16 \%, 168,170,232$. Cowley; Abraham, II3, 207 , 208; translations of Anacreon, 17; I'indaric Odes, 18, 54, 55. Cowper, William, 53, 137,138 , 159, I64; translation of Homer, ${ }_{3} 3$, 6o; The Task, go. Crashaw, Richard, 207.

Daniel, Samuel; De'liu, $21_{3}$. 
Dante, I6, 48, 143, I45, I79, I81-191, 193, 194, 197, 199, 208, 211, 212, 215, 216, 232; Canzoni, 185 ; Divine Comedy, $5,84,183,185-191 ;$ Vita Nuova, 189, 190.

Da Porto, 2 II.

Dares Phrygius, I33.

Defoe, Daniel, 226; Colonel Jack, I73, 224; Moll Flanders, I73, 224.

Demetrius Phalereus, 94.

Democritus, 9 I.

Demosthenes, 6, 29, 30, 72, 104.

Denham, Sir John, 158 .

De Quincey, Thomas, $113,245$.

Derby, Earl of ; translation of Homer, $1_{3}, 60$.

Descartes, René; Discours de la Méthode, 173.

Destruction of Troy, On the, I33.

Dictionnaire Raisonné, the, 176 .

Dictys Cretensis, 133, 134.

Diderot, Denis; the Encyclopaedia, 176 .

Diogenes, Antonius; Marvels beyond Thule, $13 \mathbf{1}$.

Dionysius of Halicarnassus, 35 .

Dionysius Thrax, 35 .

Dolopathos, 133 .

Donne, John, 207.

Dorset, Earl of. See Sackville.

Douglas, Gawin ; translation of the Aeneid, II I.

Drayton, Michael; Idea, 2 I3.

Dryden, John, 7, 56, 60, 97, $112,114,137,138,159,164$, $166,169,170,171,173,174$, 177, 196, 234, 238; Pindaric
Odes, 54, 60; Of Dramatic Poesie, 57; Troilus and Cressida, 59; translations from Latin, II 2; Dramas, Izo, I7I.

Dumas, Alexandre, 177; The Three Musketeers, 224.

Dunbar, William, 153 .

D'Urfé, Honoré, I32; Astrée, I $72,222$.

Dyer, John; The Fleece, 14, II3.

Earle, John; Microcosmography, 35.

Empedocles, 92.

"Enfants sans Souci," I65.

Epicurus, 91, 92.

Erasmus, 49.

Eulenspiegel, 237.

Euripides, 19, 21 , 59, 67; Alcestis, 21, 22, 66; Heracles, 66.

Fairfax, Edward; translation of Tasso, 203.

Farquhar, George, 78, 177.

Fichte, Johann Gottlieb, 2ł4.

Filcaia, Vincenzo da, 208.

Fielding, Henry, 78, 177; Joseple Andrew's, I73, 224; MockDoctor, 17 I.

Filelfo, 198; translation of Homer, $5^{2}$.

Flaubert, Gustave, 177.

Fletcher, Giles, 205; Licia, 2 I3. Fletcher, John, 169, 196, 229; Fair Maid of the Inn, 225; Faithful Shepherdess, 205. 
Florio, John; translation of Montaigne, 162.

Fox, Charles James, ro4.

Froissart, 160.

Frontinus, 98.

Froude, J. A., 41.

Gascoigne, George; translation of Ariosto's I Suppositi, 214.

Gay, John, 159; Fables, 34, 174 .

Ge offrey of Monmouth; History of the Britons, 249, $25^{\circ}$.

George Sand, 16.

Gesta Romanonim, 135 .

Gibbon, Edward, 100, 101, 248.

Gildas; Destraction and Conquest of Britain, 122, 248.

Giraldi, Giovanni Battista, surnamed Cinthio, 195, 211.

Gladstone, W. E., 104.

Goethe, 10, 108, 175, 231, 232, 233, 241-243, 245; Faust, 238 , 242, 243; Götz von Berlichingen, 240, 241, 246; Lyrics, 242 ; Werther, 243.

Goldoni, Carlo, 2 Io.

Gongora, Luis de, 227, 228.

Gottsched, Johann Christoph, 239.

Gower, John, 111, I34, 163, 177; Confessio Amantis, 195.

Gray, Thomas, 7, 39, 53, 55, 61, 234; The Bard, 6r; Progress of Poesy, 18, 54, 61; translations from Statius, 85 .

Greek Anthology, the, 28.

Greene, Richard, 205, 214 ; Friar Bacon, 238, 245.
Gregory of Tours; History of the Franks, 122.

Gregory the Great; Moralia, 122.

Grocyn, William, 49, 199.

Guarini, Giovanni Battista, 132; Pastor Fido, 205.

Guevara, Antonio de; Golden Book of Marcus Anrelius, 228; Golden Letters, 228.

Guinicelli, Guido, 189.

Guzman de Alfarache, 223.

Hall, Edward; Characterismes of Virtues and Vices, 35, 97.

Hardy, Alexandre, I32.

Harington, Sir John, 203.

Harvey, Gabriel, 213.

Hegel, Georgr Wilhelm Friedrich, 244 .

Heine, Heinrich, 32, 231, 241, 244; Buch der Licder, 242.

Heliodorus, 36; Aethiopica, 13 I.

Herder, Johann Gottfried von, 239.

Herodotus, 28, 33, 160.

Herrick, Robert, 15, 16, 17, 87 . Hesiod, 14, 46, 62, 9o; Theogrony, 14; Works and Days, 14.

History of Alexander, 134.

Homer; Iliad and Odyssey, 5, $9^{-1} 3,15,39,4^{0}, 4^{2}, 45,4^{6}, 49$, $59,60,61,62,64,68,69,72$, $81,82,83,107,134,184,185$; translations, $13,49,52,60$, 64.

Hooker, Richard, 50. 
Horace, $45,46,72,73,75$, So, $85-87,107$, I 10, 112 , I14; $D e$ Ante Poetica, 6, 90, 91, I 12 ; Epistles, 95, I12; Odes, 86, 87,88 ; Satires, 95, 96, 97, I 12.

Hrotswith, 122.

Hugo, Victor, 159, 175; Les Misérables, I77; Notre Dame, 177.

Hume, David, $13^{8}$.

Hunt, Leigh, 213 .

Iamblichus; Babylonica, 13. isidore of Seville; Origines, 122.

Jerome, St., 71, 117; translation of The Bible, 117, 123 .

Jodille, Etienne: Cléopître, 165 , I 66.

John of Damascus; Barlaam and Josaphat, 132.

Jonson, Ben, 24, 76 , I12, II 3 . 209, 229, 234.

Johnson, Samuel, $113,1_{4}, 1_{3} 8$, 159, 174, 251, 252; Lonton, 97, 113; Vanity of Human Wishes, 97, 113 .

Jordanes, 122.

Juvenal, $76,95-97, \quad$ 10 8, I 12 , 113.

Kalila and Dimna, 129, 219.

Kant, Immanuel, 244.

Keats, John, 43, 44, 63,64, 197; Endymion, 39, 63; Hypcrion, 22, 63; On first looking into Chapman's Homer, $13,64$.
Klinger, Friedrich Maximilian von; Sturm und Drang, 240. Klopstock, Friedrich Gottlieb, 233; Messias, 239.

Koran, the, $\mathbf{1} 28$.

La Bruyère, Jean de; Characters, 35, 17t.

La Calprenède, Gautier de, I32, 172, 222, 250; Cléopître, 173; Cassandre, 173 .

Lactantius, 7 1 , I 17 .

La Fayette, Madame de, 173.

La Fontaine, Jean de; Fables, 34, 174 .

Lamartine, Alphonse, I 75, 243. Landor, W. S., 31, 113, 21 3 ; Hellenics, 39, 66; Imaginary Conversations, 174 .

Langland, William; Piers Plozeman, 126.

La Rochefoucauld, Duc de, 174. Lazuer Patelin, $16_{5}$.

Layamon; Brut, 249, 250.

Lazarillo de Tormes, Life of, 223.

Leibnitz, Baron von, 233, 244, 245 .

Lesage, Alain René, 173, 220; Diable Boiteux, 175, 224; Gil Blas, $173,175,224$.

Lessing, Gotthold Ephraim, $231,233,238,239,240,241$, 245; Laocoon, 241; Minna von Barnhelm, 241; Natluan the Wise, 241.

Linacre, Thomas, 49, 199.

Livy; History of Rome, 75, 8o, 99-IOI, IO8, III, II 4 . 
Locke, John, $x 76$.

Lodge, Thomas, 205; Phillis, 213.

Longinus; On Sublimity, 35, $57,241$.

Longus; Daphnis and Chloe, $35,132$.

Lope de Vega, 166, 228, 229.

Loqman ; Fables, 129.

Lorris, Guillaume de; Roman de la Rose, 148.

Lovelace, Richard, 17,87 .

Lucan, $71,75,111,112,114$; Pharsalia, 84 .

Lucian, 31; True History', 32, 62.

Lucilius, 95, 96.

Lucretius, 75, 80, 91-93, 108, I13, I14; De Rerum Natura, 91,92 .

Luna, Alvaro de, 223.

Luther, Martin, 237, 243; " Ein feste Burg," 232; translation of The Bible, 238 .

Lydgate John, 111; Falls of Princes, 196; Troy Book, 134,

Lyly, John, 205; Euphues, 206, 227.

Macaulay, Lord, 29, 99, 100, IoI, 241; Lives of Chatham, Clive, and Hastings, 33.

Machiavelli, r29; Il Principc, 2 ro.

Macrohius; Saturnalia, 117.

Macpherson, James; Ossian, $251,25^{2}$.

Malherbe, François, 158, 160, $163,164,166$.
Nalory, Sir Thomas; Morte D'A rthur, 250.

Map, Walter, 142, 151.

Margites, 61.

Marie de France, I 42 , I51.

Marini, Giovanni Battista, 207.

Marivaux, Pierre, 173; Marianne, 175 .

Marlowe, Christopher, 50, II I, 214; Dr. Faustus, 238, 245.

Manuel, Juan ; Count Lucanor, 2 I9.

Marot, Clément, ${ }^{153^{-1}} 55,157$, $163,205$.

Marseillaise, La, 15.

Martial, 28, 71, 97, 98, 111, 112, 156.

Mason, William, 18,54 .

Massinger, Philip, 215.

Menander, 19, 24, 46, 77.

Mendoza, Diego de; Lazarillo de Tormes, 223 .

Metastasio, 2 ro.

Meung, Jean de, 148 .

Middleton, Thomas; Spanish Gipsy, 225.

Nilton, John, $7,53,68,8_{3}$, I 2 , $113,136,179,187,208,211$, 234, 239, 250, 254; Comus, 39, 208, 209, 249; Epitaphium Damonis, 249; Il Penseroso, 208; L'Alle gro, 208; Lycidas, 15, 26, 27, 56, 59, 88; Natizity Odc, 59; Paradise L.ost, 5,8 , 22, 81, 84, 93, 1 $85,192,203$, 204; Paradise Regained, 93, 201; Samson Agonistes, 23, 59; Sonnets, 208.

Mirror for Magistrate's, the, 196. 
Molière, $24,77,78$, I 39, I 70, I7 I; Les Fourberies de Scapin, 77; other plays, i7r.

Mommsen, Theodor, 23I, 245 .

Montaigne, Michel de; Essais, $33,96,161,162,172$.

Montemayor, Jorge de; Diana, I $72,221$.

Montesquieu, Baron de; Esprit des Lois, 176 .

Moore, Thomas, 17 .

More, Sir Thomas, I13, I6I; Utopia, 32, 39.

Morris, Willian, 41, 67; Ealthly Paradise, 67, 117; Jason, 39, 67; translation of Homer, 13 , 60,67 .

Moschus, 6, 25, 56, 69.

Mouthfuls of Gold, 219.

Muqaffa, I29.

Naevius, 78 .

Nash, Thomas; Jack Wilton, 224.

Nennius, 248 .

Nepos, Cornelius, 99, 134 .

Newman, Cardinal, 4 I, 254.

Nibelungen Lied, the, 125,232 , $235,236$.

Niebuhr, Bartholet George, 245.

North, Sir Thomas; translation of Plutarch, 33, 52, $5^{8}$.

Orosius, I2I, I 22.

Ossian, 25I, 252.

Overbury, Sir Thomas; Characters, 35 .
Ovid, $47,75,80,87,107$, I10, I 14, I2 I, I43, 148, 156, 198; Amores, 88; Fasti, 88; Heroides, 88, i 1 2; Metamorphoses, 93, 94, I I ; Tristia, 88.

Painter, IVilliam; Palace of Plcasure, 2 I4.

Palmerin, Romance of, 220.

Pancatantra, the, 129.

Parables of Sandabar, the, I33.

Parmenides, 92.

Pascal, Blaise; Provincial Letters, 173 .

Pausanias, 35 .

Peele, George, 205.

Persius, 96.

Petrarch, 48, 49, 145, 158, 179, I89, 190, 191-194, 199, 208, 212, 213; Africa, 192; Canzoniere, 194; Sonnets, 193, 194, 197; Trionfi, 194.

Petronius; Satyricon, I2I.

Phaedrus, 94, 134.

Phocylides, 18.

Phrynichus, 6r.

Pilpay, 34, 129, 135, 219.

Pindar, I6, I $7,18,45,46,54$, $55,60,61,69,158$.

Piron, Alexis, 174 .

Pitt, Villiam, ro4.

Plato, 6, 30, 31, 39, 62, 66, 102, I18, r29; Ideal Commonwealth, $3 \mathrm{I}$.

Plautus, $24,46,75,76-78,80$, 107, iा iा i2, 198, 209; Menaechmi, 77 .

"Pléiade, the," I 55, I63, I65. 


\section{AUTHORS AND WORKS}

Pliny the Elder; Natural History, 98, 99, 121.

Pliny the Younger, 79,105 , 106, $108,113,173$.

Plutarch, 32, 33, 62; Lives, 33, 52, 58; Amyot's translation of, 16I; North's translation of, $33,5^{2}, 5^{8}$.

Poliziano, Angelo, 199, 209; Favola di Orfeo, 205.

Pope, Alexander, 4o, 42, 43, 44, $8_{3}, 97,109,1_{3}, 1_{14}, 1_{3} 8,1_{5} 8$, 164, 177, 234, 251, 252; Dunciad, 6o; Essay on Criticism, 6, 58, 60, 90, 159: Essay on Man, 8, 245; Ode on St. Cicilia's Day, 54; Pastorals, 5 , 25, 26, 55, 56, 60, 112; Rape of the Lock, 6o, 208; translation of Homer, 6o; other imitations of the classics, 85 , II2.

Poquelin, Jean Baptiste. See Molière.

Prévost d'Exiles, Abbé ; Manon Lescaut, 175 .

Prior, Matthew, 174.

Propertius, 87, 88.

Proierbs of Solomon, the, 19.

Prudentius, I17, I2I.

Pulci, Luigi, I99; Morgante Maggiore, 200.

Puttenham, George, 212; Art of English Poesy, 57.

Quevedo, Francisco de: Life of Buscon, 223.

Quintilian, 71, 84, 99, 102; Training of the Orator, $\mathrm{IO}_{3}$.
Rabelais, François; Gargantua and Pantagruel, $\mathbf{1 6}$.

Racine, Jean Baptiste, 22, 79 , 132, 139, 158, 166, 168, 170.

Raleigh, Sir Walter, 50.

Ranke, Leopold von, 245.

Rapin, 17o.

Reineke Fuchs, 236.

Richardson, Samuel, 173, 175,

177; Clarissa Harloa'e, 173;

Pamela, 173, 175.

Richter, Jean Paul, 233.

Rinnucini; Dafne, z ro.

Roland, the Song of, $14^{2}$.

Roman de Renard, the, I49, 236.

Romance of Alexander, the, ${ }_{1} 6_{3}$.

Romance of the Rose, the, III, 148,163 .

Ronsard, 156, 157, 192.

Roscommon, Earl of, 160, I75; Essay on Translated Verse, 0 , 57 ; translation of Horace's Ars Poetica, i 2.

Rossetti, D. G., 190, 192.

Rousseau, Jean Jacques, I39,

177; Confessions, 175, 176;

Contrat Social, 176.

Rucellai, Giovanni, 210.

Ruskin, John, +1, 213 .

Sacchetti, 195 .

Sachs, Hans, 232, 237.

Sackville, Thomas, Earl of

Dorset, III, 160, 177, 214.

St. Amant, i6o.

Saint-Evremond, 174 .

Saint-Gelais, $157,192$. 
St. Pierre, Bernadin de; Paul ct Virginie, $175,177$.

Ste. Beuve, Charles Augustin, 177 .

Sallust, 75, 99, 100, 107.

Sannazaro, 5, 25, 55, 89,204 , 205, 213; Arcadia, 205, 221.

Sappho, 16, 45, 46, 54, 72, 107.

Sardou, Victorien, 77, 177 .

Scarron, Paul, I73, 224.

Schelling, Friedrich von, 244.

Schiller, Friedrich, 10, 108,231 , 233, 240-242; Robbers, 240; Song of the Bell, 242; IVallenstein, 241, 242; Wilhelm Tell, 242.

Schlegel, A. W. and Friedrich von, 245 .

Schopenhauer, Arthur, 231, 244 .

Scott, Sir Walter, I6o; translation of Goethe's Götz, 246.

Scudéry, Mademoiselle de, ${ }^{3} 32$, 172, 222, 250; Clélic, I73; Grand Cyrus, 173 .

Sedley, Sir Charles, 160.

Seneca the Elder, 98.

Seneca the Younger, $71,72,75$, $76,78,79,102,103,107$, Iі, I 12, I61, I66, 198, 209; Moral Epistles, 103.

Ser Giovanni; Pecorone, $2 \mathrm{II}$.

Seven Sages, the, 195.

Seven Wise Masters, the, I33. Sévigné, Madame de, 105, 173. Shakespeare, William, 7 , 20, $24,50,51,52,59,76,161$, I66-170, 184, 185, 193, 2II, $215,220,227,232,234,243$,
245; Antony and Cleopatra, 58; Comedy of Errors, 77; Coriolanus, 33, 58; Hamlet, I 7 ; King Lear, I7I; Love's Labunr's Lost, 169, 205; Measure for Measure, 169; Romio and Juliet, 214; Sonnets, 192, 213 ; Taming of the Shrew', 220; Two Gentlemen of Verona, 221; Venus and Adonis, 111 ; Winter's Tale, 169; plots taken from the Classics, 33 , $52,5^{8}, 77,94,111$; from the italians, 195, 205, 214, 219, 221 ; familiar with Florio's Montaigne, 162.

Shelley, P. B., 7, 197, 213, 233, 243; Adonais, 15, 26, 56, 63; Defence of Poetry, $5^{8}$; Epipsychidion, 63; Hellas, 6, 62, 63; Ode to a Skylark, 8; Ode to Liberty, 55, 63; Prometheus Unbound, 22, 39, 62 .

Shenstone, William, 5 .

Sheridan, Richard, 78 ; Sclzool for Scandal, izi.

Ship of Drunkards, the, 237.

Sidney, Sir Philip, 50, 55, 161, 192, 213, 214; Arcadia, 39, 56, 205, 22 ; Defence of Poesie, 57,214 ; Sonnets, 213.

Simonides, 16, 17, 27, 54, 69 .

Smollett, Tobias, i 7 ; Peregrine Pickle, 224; Roderick Random, $173,224$.

Song of Widsith, the, 125 .

Sophocles, 6, 19, 20, 59, 68; Philoctetes, $2 \mathbf{r}$.

Spectator, the, 138, 173 . 
Spenser, Edinund, 5, 41, 43, +4, 50, 51, 52, 56, 59, 60, 89, 9.3, I 54, 192, 208, 234, 249, 250; Amoretti, 190, 2 i 3 ; Astrophel, 56, $5^{8 ;}$ Daphnaida, 56, $5^{8}$; Eclogues, I I ; Farrie Quenne, 42,58, I I I, 197, 200, 201, 203; Shepheard's Calender, $25,26,55,56,5$, 221 ; Sonnets, 213 .

Staïl, Madame de, I75.

Statius, 47, 84,85 , I I I, II 4 ; Thebaid, 84 , I I .

Steele, Sir Richard, 174, 177.

Sterne, Laurence, 32, I6I.

Strabo, 35 .

Straparola, Giovanni Francesco, $21 \mathrm{x}$.

Stratagems of Vomen, the, 219.

Suckling, Sir John, $17,87$.

Suetonius, 99, I00; Lives of the Talelie Caesars, noo.

Surrey, Earl of, I I I, 153, 179, 192, 193, 212 ; Sonnets, 212, 213 ; translation of Virgil, I I , 214.

Swift, Jonathan, 161, 17.4, 226; Battle of the Books, 62; Gullizer's Travels, 32, 62; Tale of $a T u b, 62$.

Swinburne, A. C., 4I, 54; ttalanta in Calydon, 22, 67 .

Sylvester, J.; Week of Creation, 157.

Syntipas, 133 .

Tacitus, 76, I00, Iо I, I08, I 17.

Tasso, Torquato, 132, 179, 196, 197, 203, 204, 208, 21 1, 213;
Aminta, 204; Gerusalemme Liberata, $8 \mathrm{r}, 200,203 ; \mathrm{Il}$

Mondo Creato, 204.

Tassoni Alessandro; La Secchia Rapita, 208.

Taylor, Jeremy, I I 2, 254 .

Tennyson, Lord, $7,+1,44,58$, $67-69,83,109 ;$ Idylls of the King, 251 ; In Memoriam, s, I5, 57; Lotus-Eaters, 39, 69; Oenone, 57, 69; Tithonus, 69, translations from Homer, I3; Ulysses, 69.

Terence, $24,46,75,76-78,80,107$, I 1 2, 122, 209; Phormio, 77.

Tertullian, $7 \mathbf{I}$, I $\mathbf{7} 7$.

Theocritus; Idylls, 6, 25, 26, 27, $4^{0}, 4^{6}, 55,56,59,62,63,68$, $69,89,107,112,204$; translation of, 27.

Theodore of Tarsus, $\mathbf{I} \mathbf{3} \mathbf{I}$.

Theognis, 18 .

Thomson, James, 197.

Thucydides, 29, 62 .

Tibullus, $\mathrm{S}_{7}$, I 56 .

Tottell's Miscellany, 2 I3.

Trapassi, Pietro, called Metastásio, 2 ro.

Trissino, Gian Gorgio, I66, 214 ; Sofonisba, 210.

Turbervile, Georse, 205.

Tusser, Thomas; Five Hundred Points of Good Husbandry, I4.

Tyrtácus, I 5 .

Uhland, Ludwig, 23 I.

Valla, Lorenzo, 198. 
Vanbrugh, Sir John, 177; The Mistake, 17 .

Varro, 98.

Vega, Garcilaso de 1a, 227.

Villon, François, $153-155,163$.

Vincent of Beauvais, 133 .

Virgil, 45, 72, 73, 75, 79, 80, 85, 107, I10, III, II4, I16, I2I, 143, 188, 198; Aeneid, 5, 81$84,93,111,112,185,186,203$, 214; Eclogues, 25, 26, 55, 89, 90, $111,112,204$; Georgics, 90, 113 .

Voiture, Vincent, I6o.

Voltaire, 32, 139, 168, 176, 239; Candide, 175; Henriade, 174; Zaïre, I74.

I'utgate, the', $47,117,120$.

Wace, Robert; Geste de's Brrtons, $150,249$.

Wacht an Rhein, I) ie, 15.

Waller, Edmund, $17,87,137$, $158,160$.

Walpole, Horace; Ietters, 105 , 113, 173,177 .
Walter of Oxford, 249.

Watson; Passionate Century of Loz'e, 212.

Way, A. S.; translation of Homer, 13 .

Webster, John, 215.

Wieland, Christoph Martin, 233, 239.

Winckelmann, 245.

Wordsworth, William, 43, 44, 115, 175, 233; Excursion, 93; Ode on the Intimations of $1 \mathrm{~m}$ mortality, $3^{1} ;$ translations from Chiabrera, 208.

Wyatt, Sir Thomas, III, I53, 179, 192, 212.

Wycherley, William, 138, 177; The Plain Dealer, i 7 .

Wyclif, John; translation of The Bible, 46, 47, $25^{6}$.

Xenophanes, 92.

Zola, Emile, i77. 


\section{HANDBOOKS OF ENGLISH LITERATURE}

EDITED BY PROFESSOR HALES.

"The admirable series of handbooks edited by Professor Hales is rapidly taking shape as one of the best histories of our literature that are at the disposal of the student. ... When complete there is little doubt that we shall have a history of English literature which, holding a middle course between the rapid general survey and the minute examınation of particular periods, will long remain a standard work."-Hanchester Guard an.

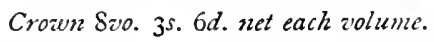

THE AGE OF CHAUCER (1346-1400). By F. J. SNELL, M.A. With an Introduction by Professor Hales.

THE AGE OF TRANSITION (1400-1579). By F. J. SNell, M.A. In 2 vols. With Introduction by Professor HALES. Vol. I.-Poetry. Vol. II.-Prose and Drama.

THE AGE OF SHAKESPEARE (r579-I631). By Thos. Seccombe and J. W. Allen. In 2 vols. Vol. I.-Poetry and Prose, with an Introduction by Professor Hales. Vol. I1.-Drama. Second Edition, revised.

THE AGE OF MILTON (1632-1660). By the Rev. J. H. B. MASTERMAN, M.A., with an Introduction, \&c., by J. Bass Mullinger, M.A. Second Edition.

THE AGE OF DRYDEN (1660-1700). By RICHARD GARNETt, C.B., LL.D. Fourth Edition.

THE AGE OF POPE (1700-1744). By John Dennis. Fourth Edition.

THE AGE OF JOHNSON (1744-1798). By Thomas Seccombe. Second Edition.

THE AGE OF WORDSWORTh (x798-r832). By Professor C. H. Herford, Litt.D. Third Edition.

THE AGE OF TENNYSON (1830-x870). By Professor Hugh Walker, M.A. Third Edition.

\section{HISTORY OF EARLY ENGLISH LITERATURE}

\section{BY BERNHARD TEN BRINK.}

\section{In Three Vols. Small Post Svo. 3s. 6d. each. Each Vol. Sold Separately.}

"It will be long before England breeds so good an historian of its own early literature as this gifted Dutchman."-Manchester Guardian.

VOL I.-TO WVCLIF. Translated into English by Horace M. KENNEDV, Professor or German Literature in the Brooklyn Collegiate Institute. Fifth Edition.

Vol. I1.-WYCIIF, CHAUCER, EARLIEST DRAMA, RENAISSANCE. 'Iranslated by W. Clarke Rorinson, Ph.D.

VOL. III.-LANCASTER AND YORK. RENAISSANCE UP TO SURREV'S DEATH. Translated by L. Doka Schinzz. 
xxiv and 505 pages. Crozen $8 v 0,5^{5}$.

\title{
HISTORY OF THE ENGLISH LANGUAGE
}

By T. R. LOUNSBURY, Professor in Yale University.

Prof. A. V. WILliams JACkson.- "You may judge how excellent a book I regard this work when I tell you 1 have used it regularly for nine years with my classes. This new edition I welcome heartily, and shall of course use it."

\section{$55^{6}$ pages. Small Crozen 8io, $5^{s .}$ \\ INTRODUCTION TO ENGLISH LITERATURE}

\author{
BY HENRY S. PANCOAST.
}

Prof. C. H. Herford, Litt. D.- "Seems to me to fulfil better, on the whole, than any other 'Introduction' known to me, the real requirements of such a book as distinguished from a 'Sketch 'or a 'Summary.' It rightly does not attempt to be cyclopædic, but isolates a number of figures of first-rate importance, and deals with these in a very attractive way. The directions for reading are also excellent."

\section{BELL'S MINIATURE SERIES OF GREAT WRITERS}

Edited by G. C. WILliAmSON, Litt.D.

Pott Svo. illustrated, Is. net, or in limp leather, with photogravure frontispiece, 2 s. nct.

Now Ready.

BROWNING. By SIR FRANK T, MARZIALS, C.B.

CHAUCER. By Rev. W. Tickwell. COLERIDGE. By Dr. GarnetT, C.B. Dante. By M. L Egerton Castle. DEFOE. By AlBiNia Wherry.

DE QUinCEY. By Henry S. Salt.

DICKENS. By W. TEIGNMouth Shore.
JOHNSON. By JOHN DENNIS.

LAMB. BY WAI.TER JERROLD.

MILTON. BY DR. WILLIAMSON.

MOLIERE. By SIR Frank T. MARZIALS, C.B.

SHAKESPEARE. By AlFred EWEN. SPENSER. HY REV. W. TUCKWELL.

HORACE. By Rev, W. TuCKwell.

\section{In Preparation.}

TENNYSON. By Dr. Williamson.

CARLYle. By Prof. Richakn Jones, Ph. D
GOLDSMITH, ByE. Lang Buckland. XENOPHON. By E. C. MaRchant, M.A. 


